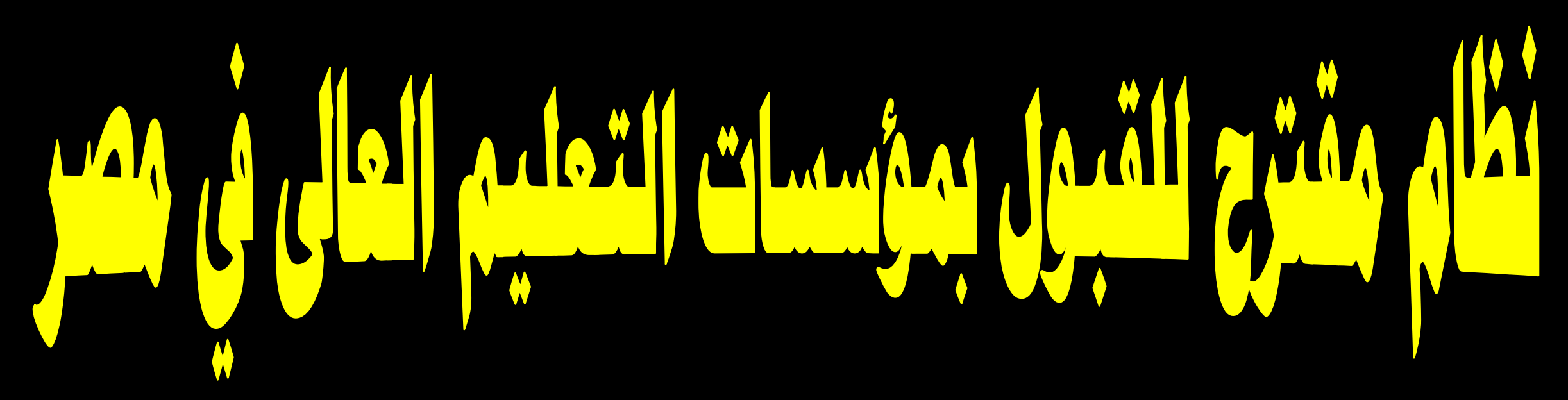

\title{
إعثاد
}

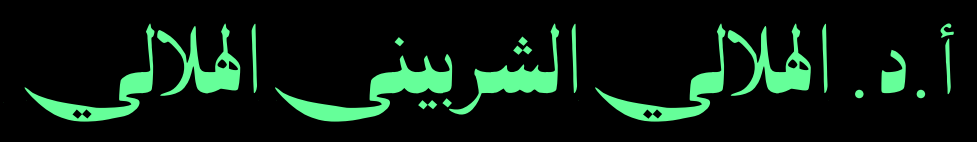

أستاذ التخطيط التزبوى والألارة التقليمية

وعميد كلية التزبية النوعية بالمصنورة النية

وفرثيها بهيت غمر ومنية النصر 


\section{فهرس الموضــوعات}

\section{مثلدمــة}

العوامل التي تُؤثر علي سياسات القبول بمؤسساتِ القمليم العالى في مصر

الميجـــور الأول

النقّام الجالي لاتبول بمؤسشات التمليم العالي في مصر (المزايا والميرب)

المحســور الثانى

بمثن الفمازج العالية المقبعة في قبول المالاب بمؤسسات القميم العالي

المحـــور الثأثث

نشّم بلديلة يمكن اتباعها في القبول بمؤسات القمايم العالي في مصر

الميجــور الرابع 
• تعد قضية القبول بمؤسات التصليم العالي من القضايا الشائكة التي تواجه الإسئولين عن

$$
\text { التقيم العالي والمهتمين بالتخطيط له في كل دول العالم تقريبًا. }
$$

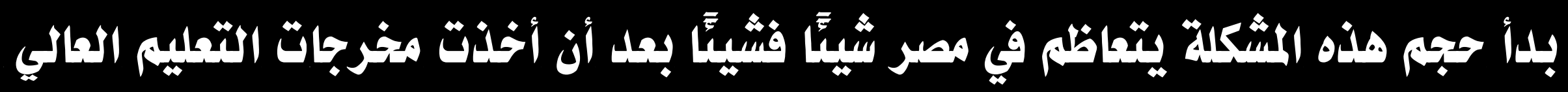

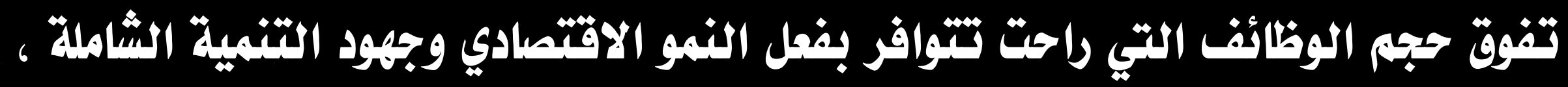

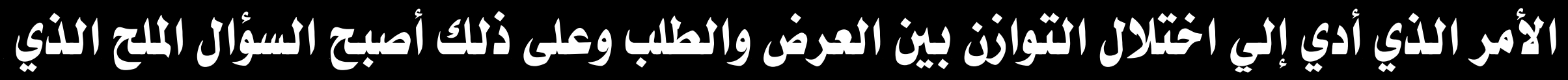

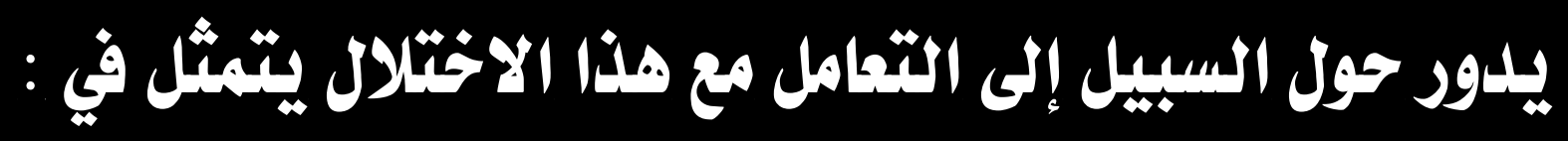

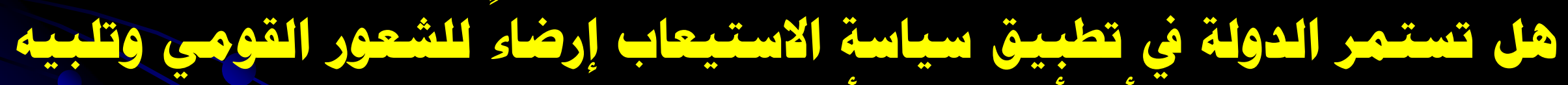

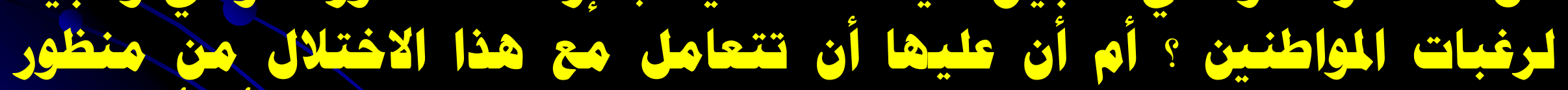

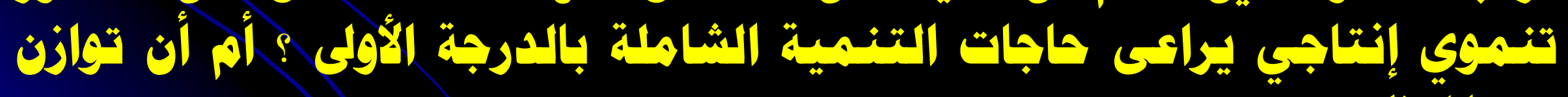

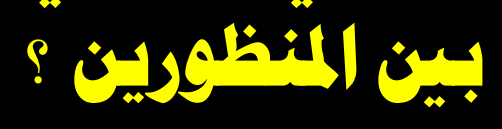

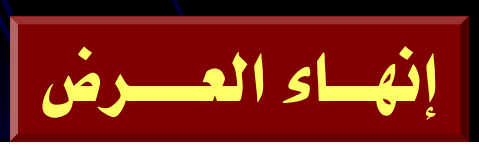




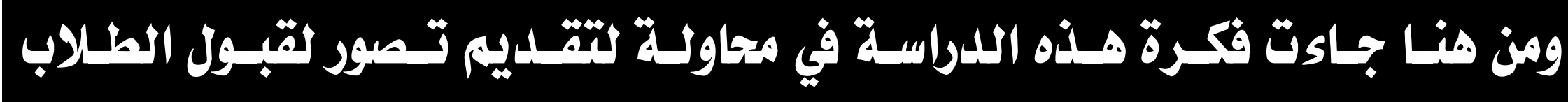

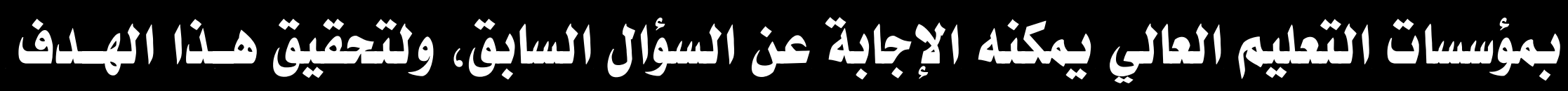
حاول فريث البحث الإجابة عن القساؤلات الثالية :

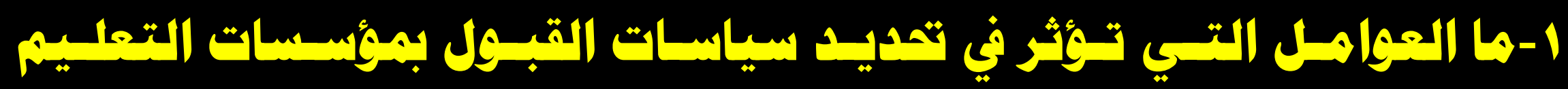
الهالي في هصرو

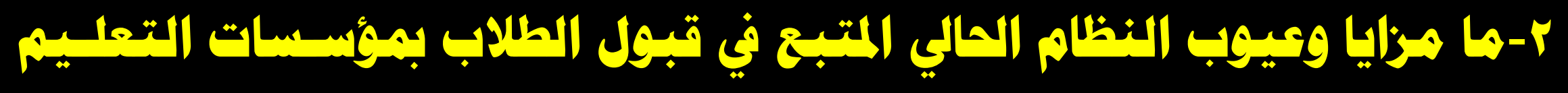

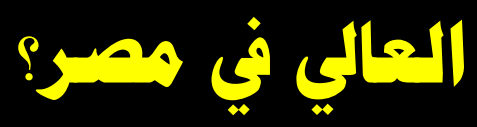

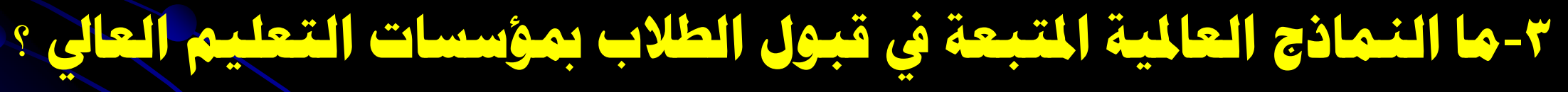

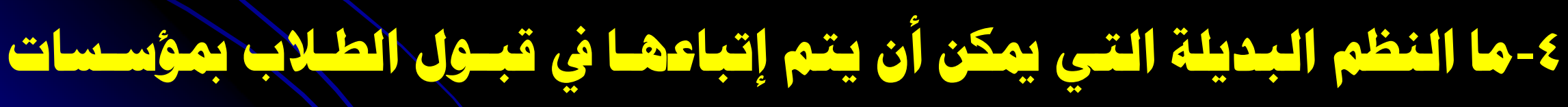
التهايم العالي في هصر؟ 


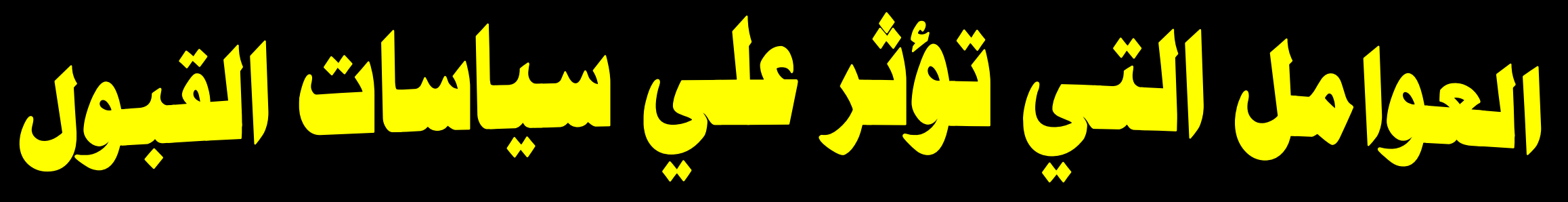

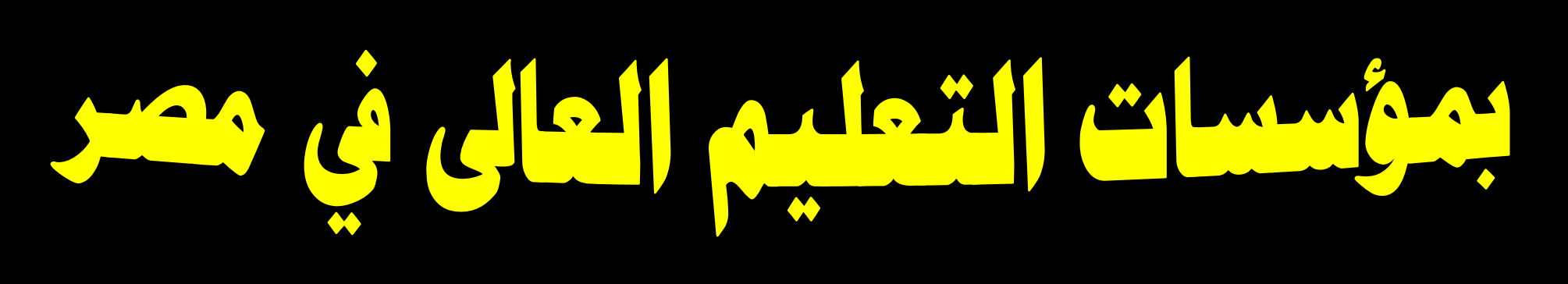

تنقسم: هذه العماهل إلى عواهل خارجية وعماهل داخلية وذلك عاى النهم التالي : 


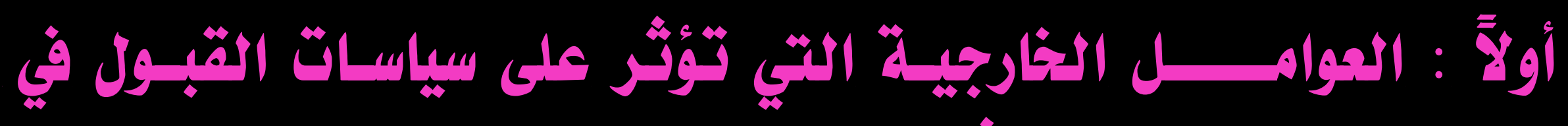

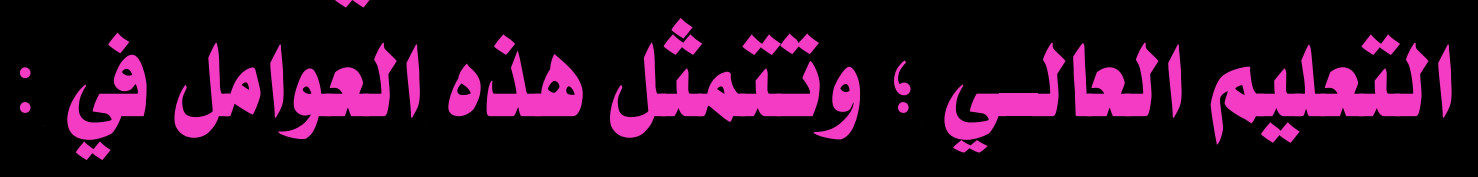

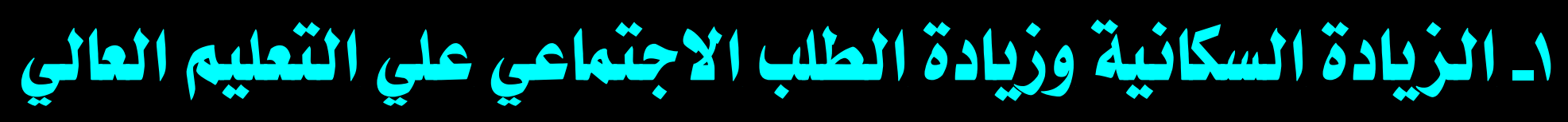

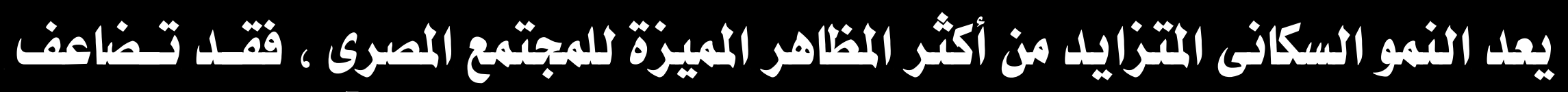

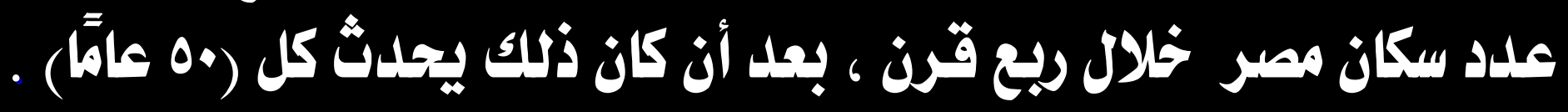

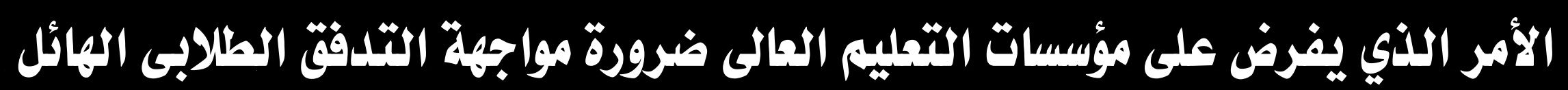

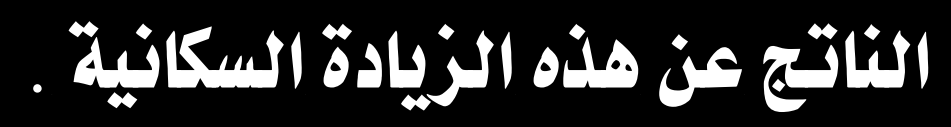

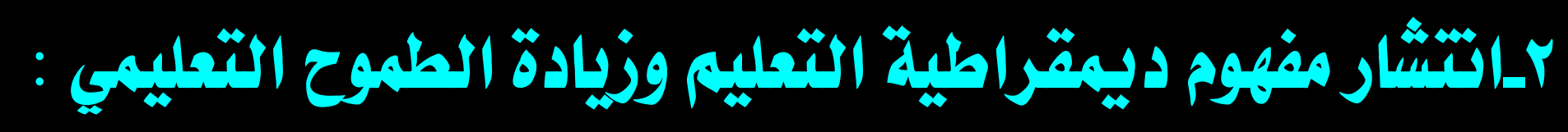

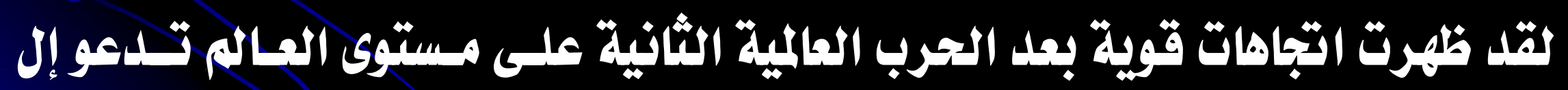

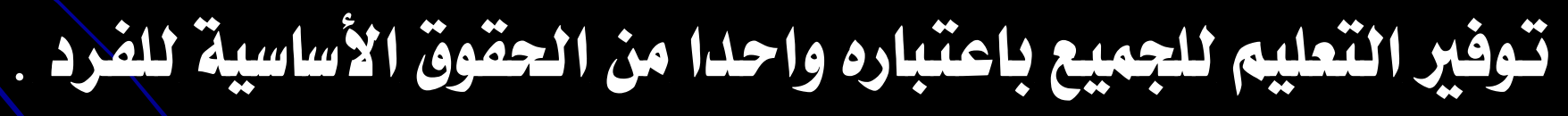

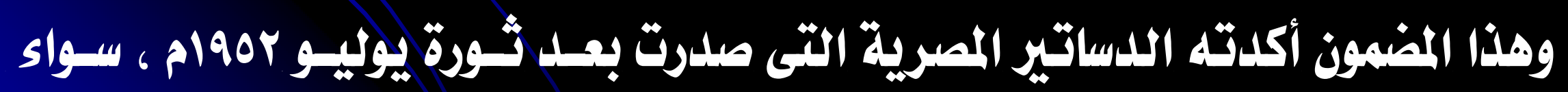

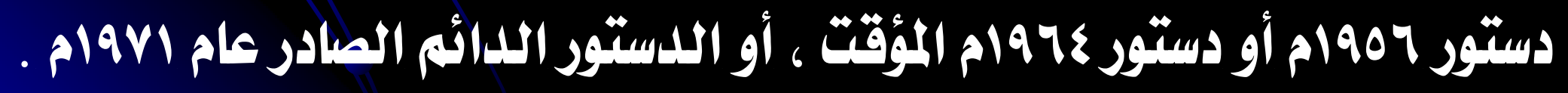

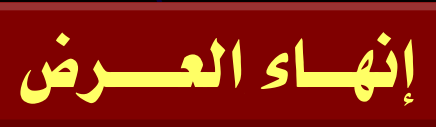

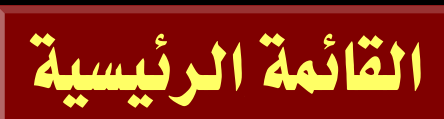
(a) 


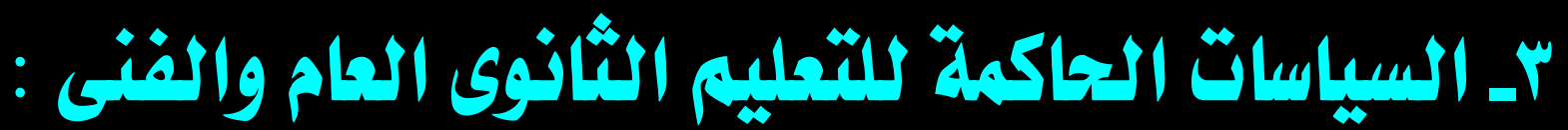

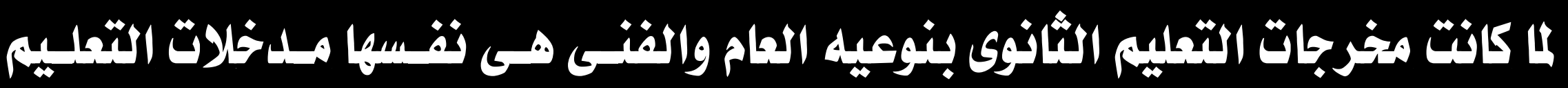

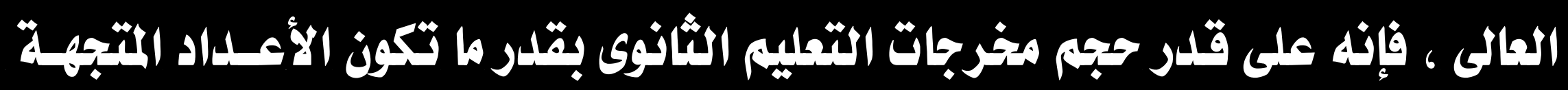

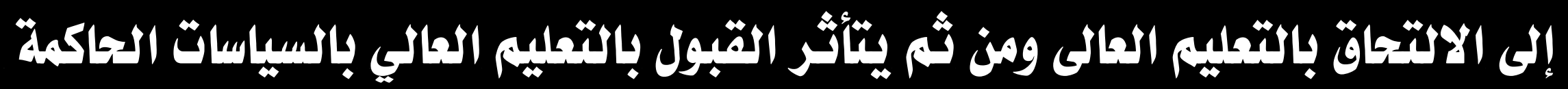

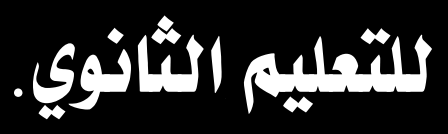

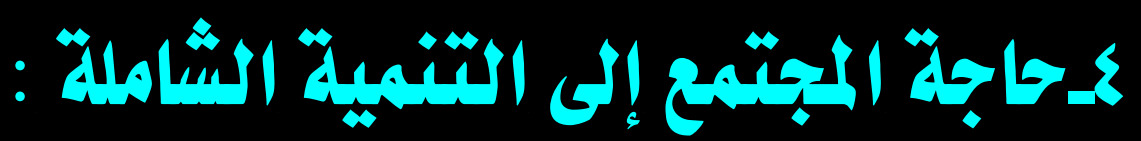

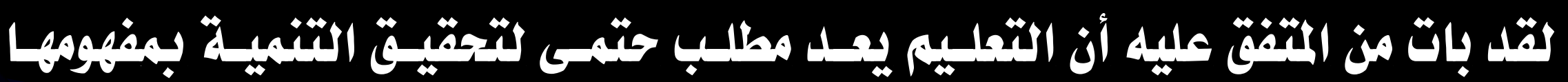

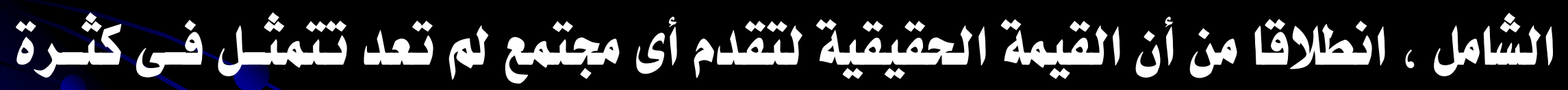

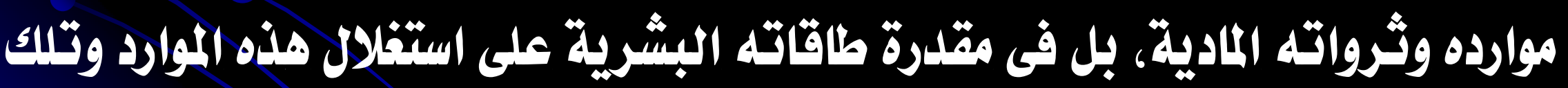
الثروات والاتثفاع بها لصالع الفرد والميتمع . 


\section{0ـ المثنيزات العالية والإستجدات العصرية :}

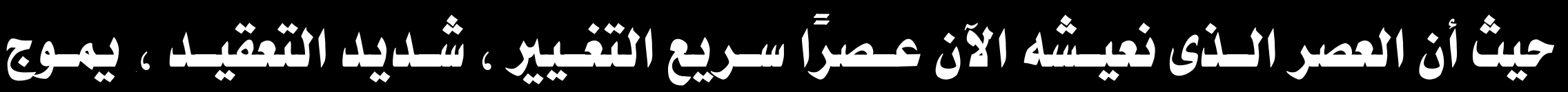

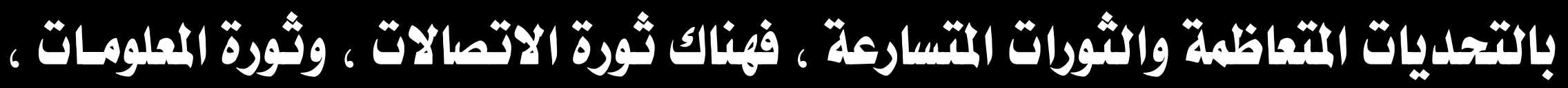

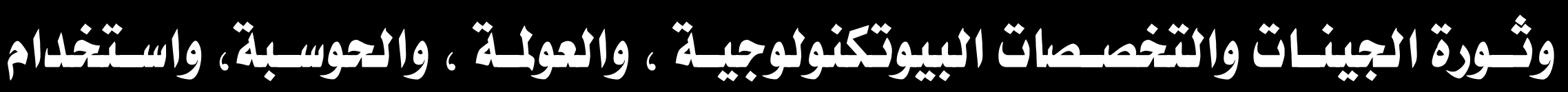

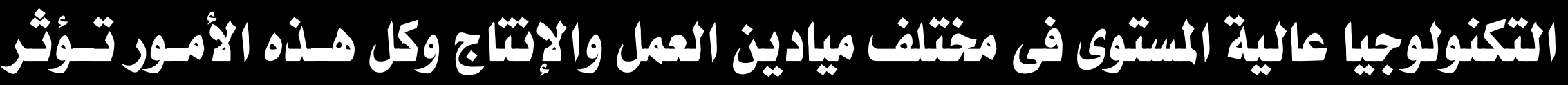

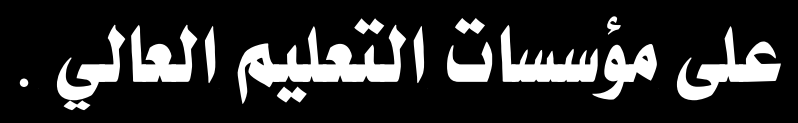

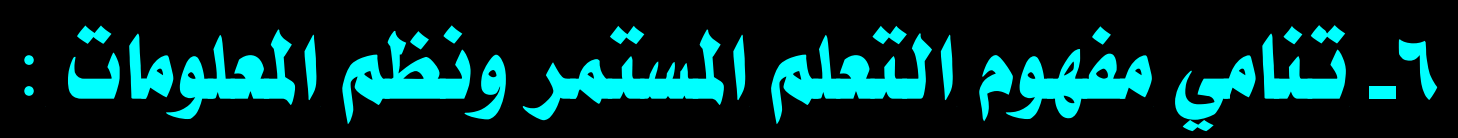

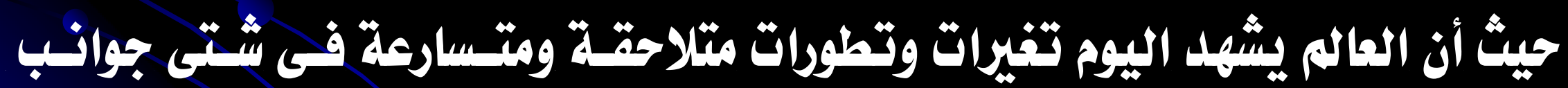

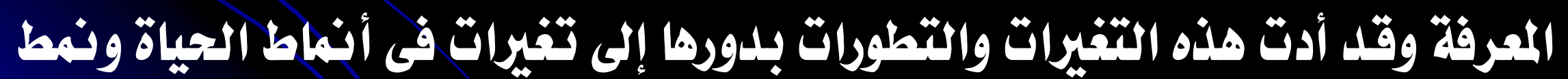

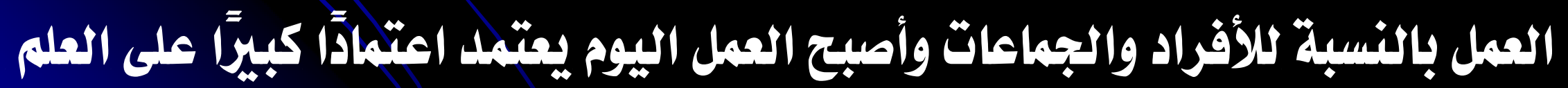




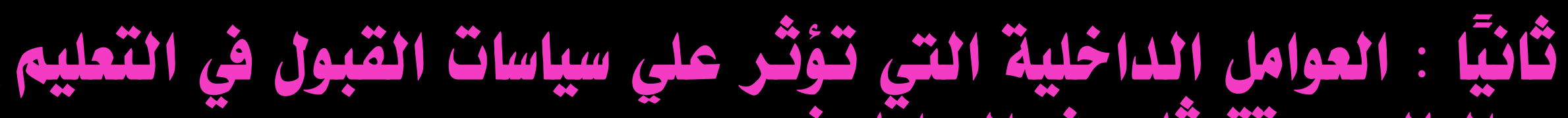

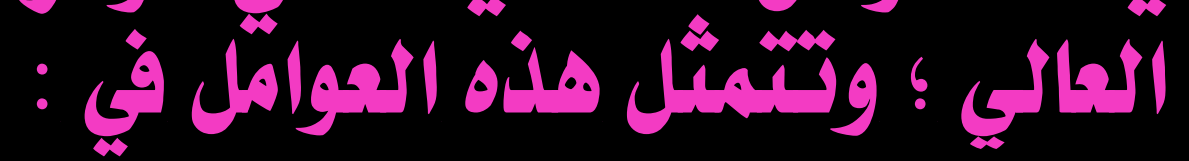

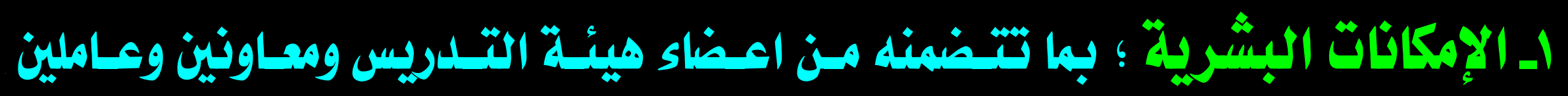

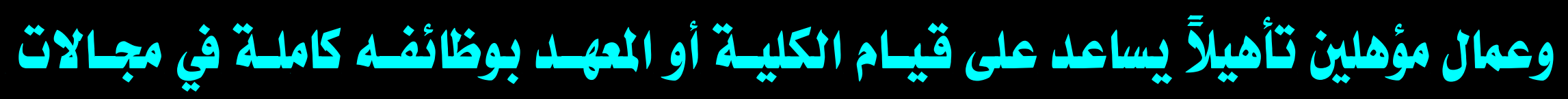

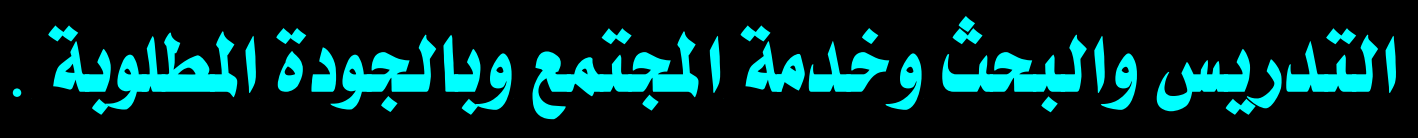

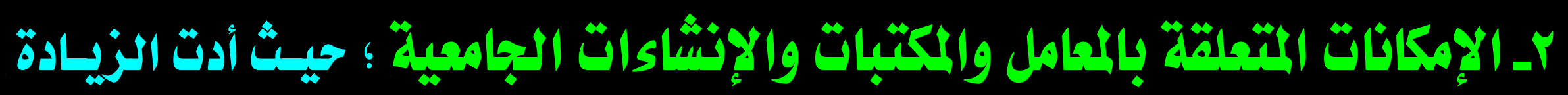

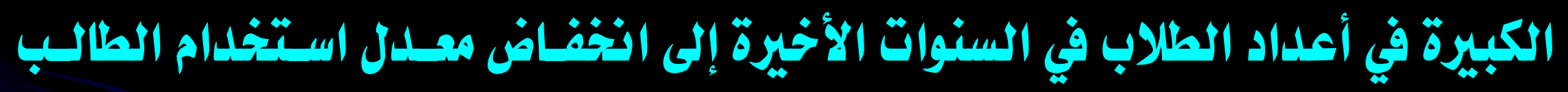

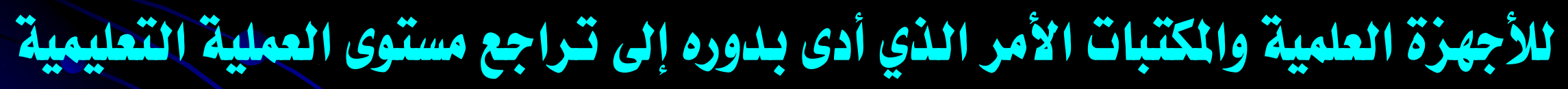

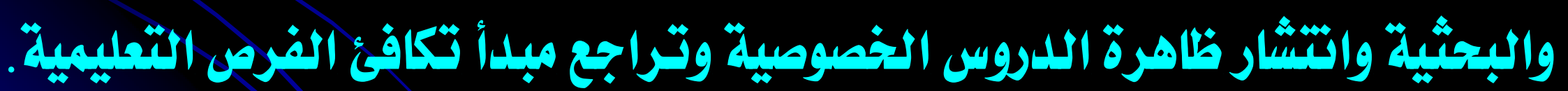

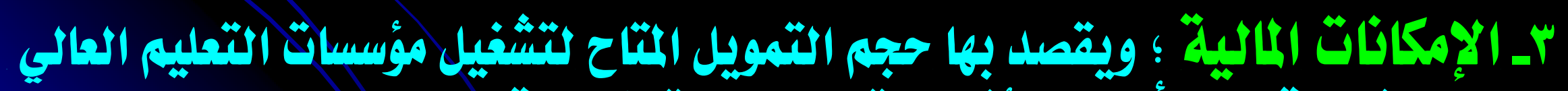

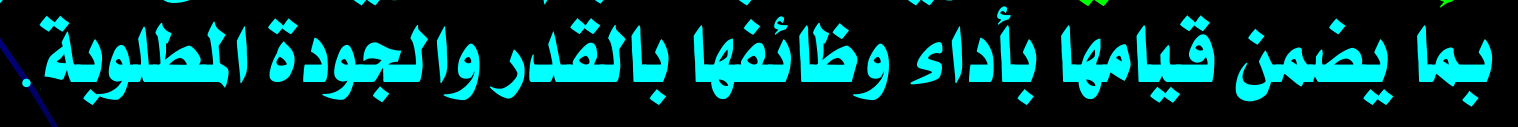




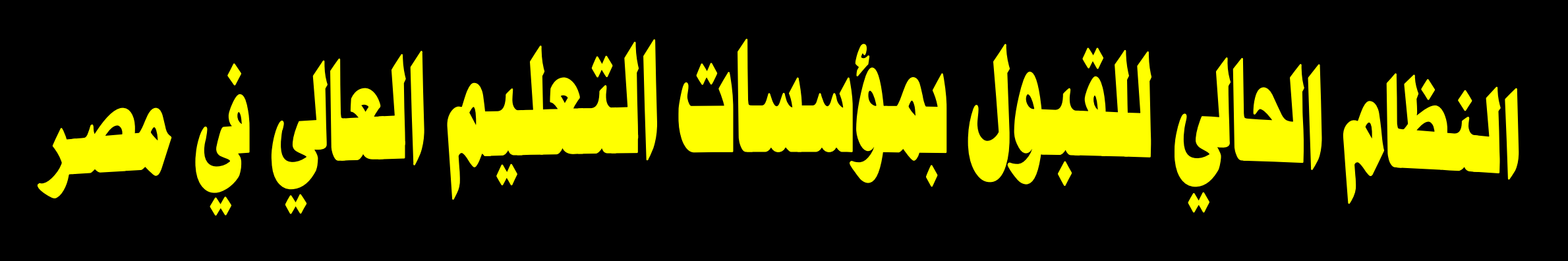

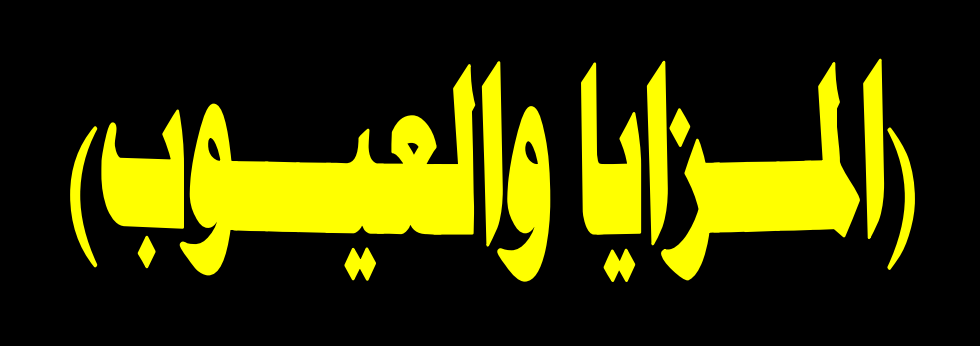




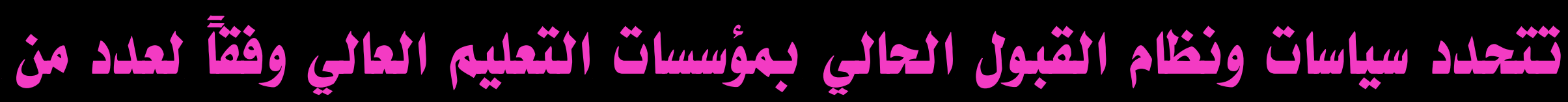

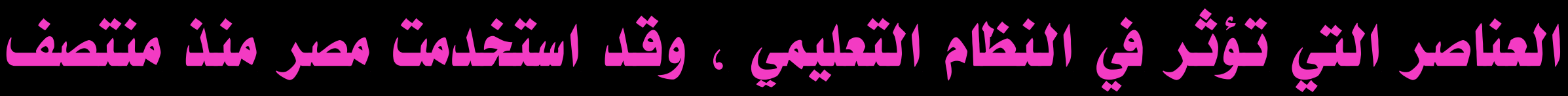

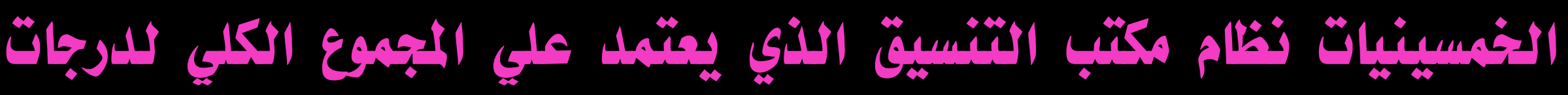

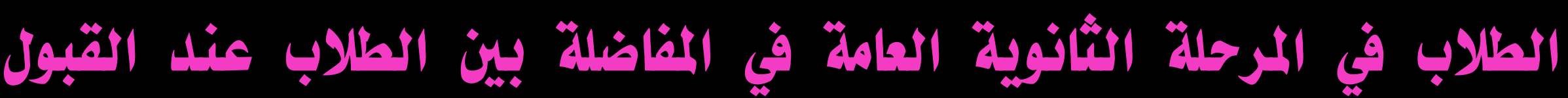

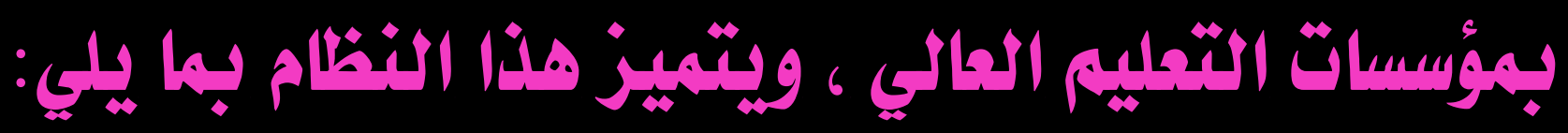

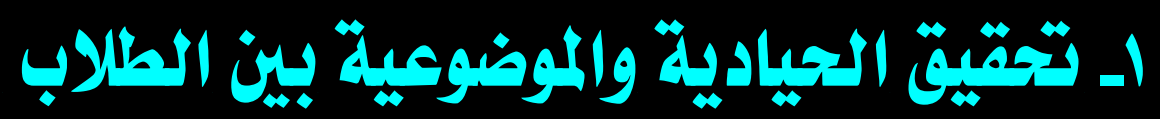
r. الاسهولة النسبية في التطبييق

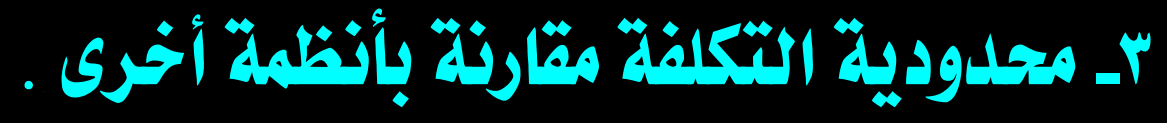




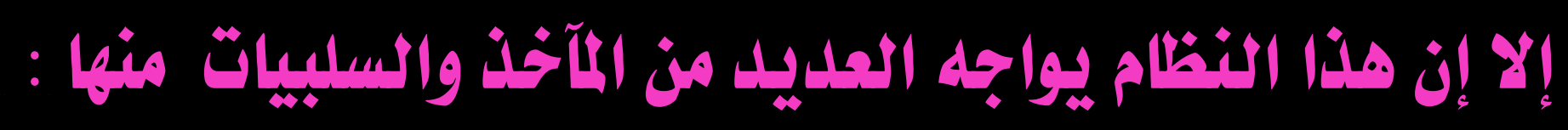

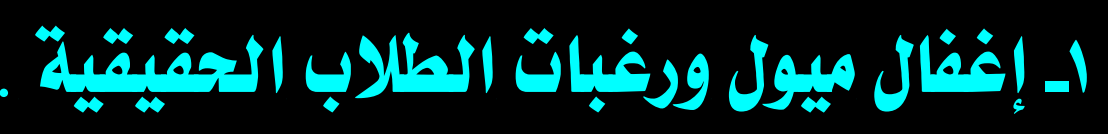
rـ غياب الأسلوب الأمثل للعكم علي قلدرات الطالاب .

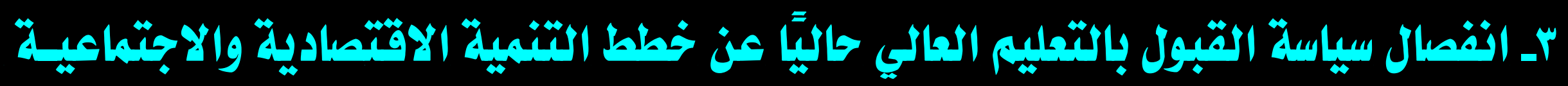

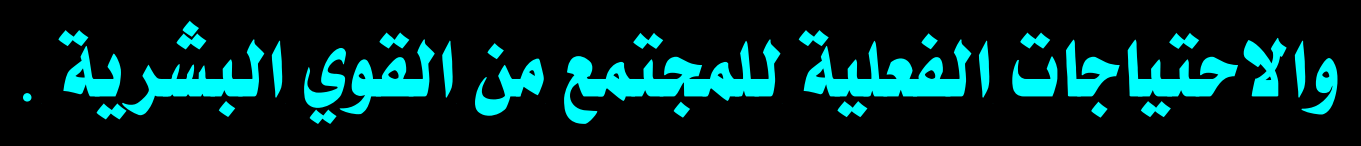

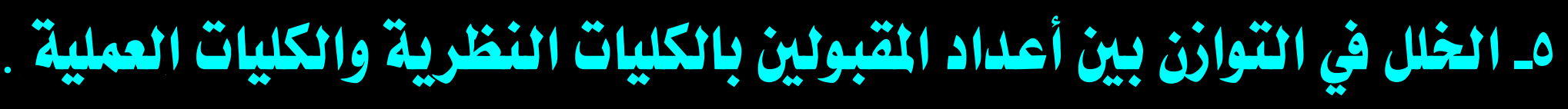
كـ إغفال قدرات وطاقات الكليات المغتلفة . 


$$
\begin{aligned}
& \text { بمض النمائه العلاية التتبعة } \\
& \text { في قبول الطالاب بيؤسسات التعميم العالي }
\end{aligned}
$$




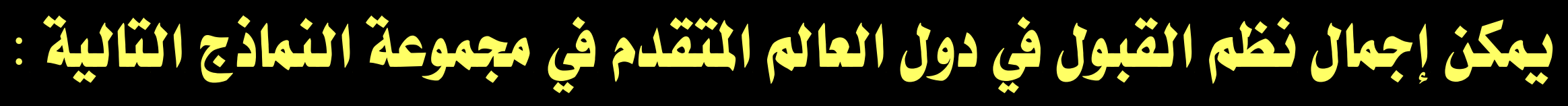

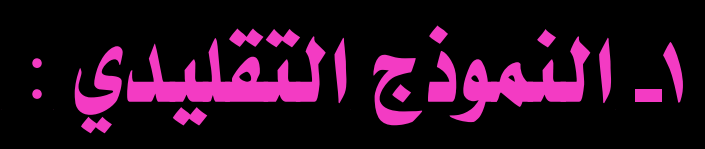

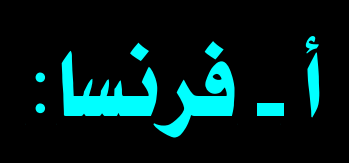

\section{Grand Ecoles إالمعاهد الكبرى}

ويقتمل القبول بهلذه الإماهل على اجثياز الطالب لحاجزين :

الأول: الوحسول على الثانوية العامة القى تؤهله للالتحاق بفصول توضريه تثتد من سنة حتى ثلاث سنوات

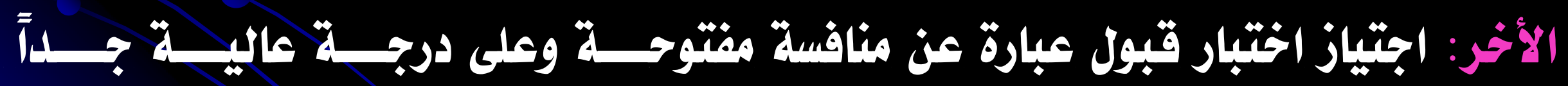

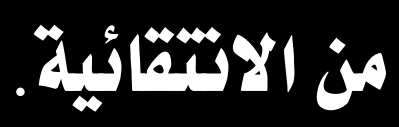




\section{Institutes University Technology إيماهد الجاميلة الثقنية}

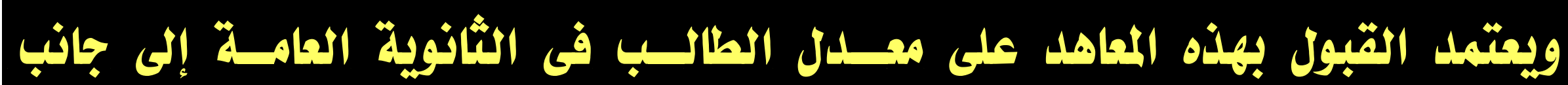
الإقابلات الشخغية.

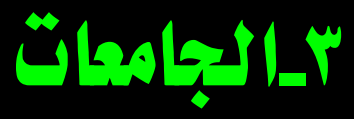

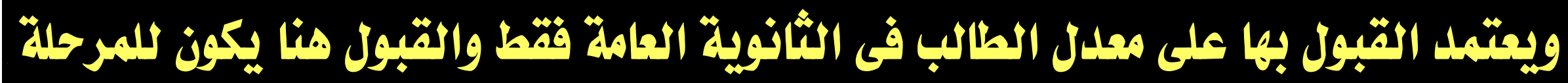

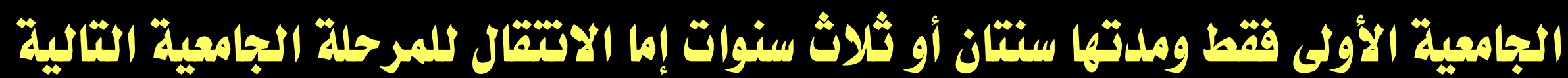

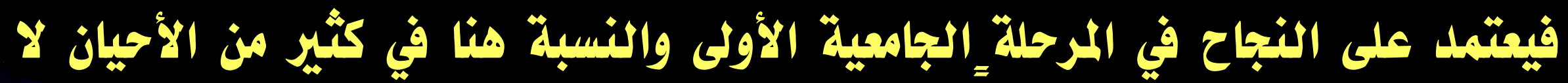

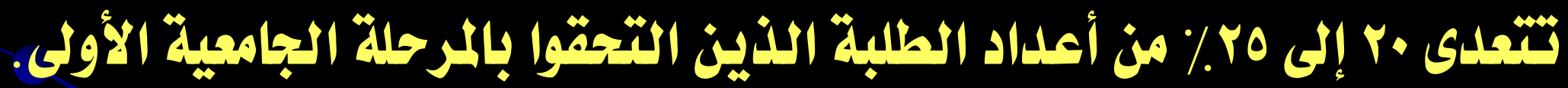

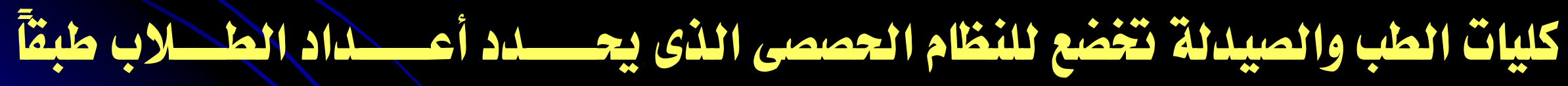

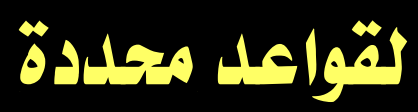




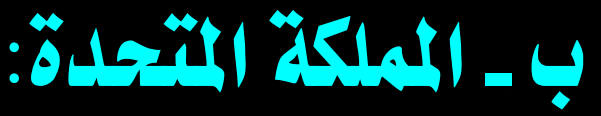

يتم القبول بمؤسسات التقليم العالي في المملكة المتحدة في ضور ثلاثة معاييز تشمل :

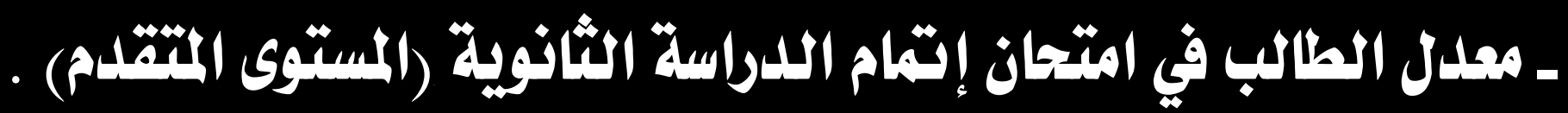
ـ التقارير الاسرية الثي يكتبها مديرو المدارس عن الطالاب.

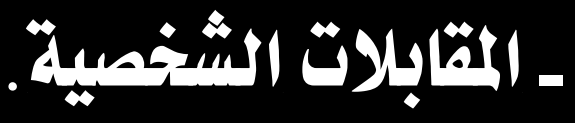

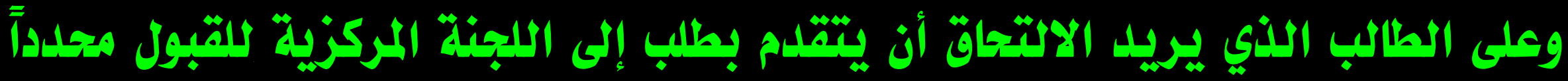

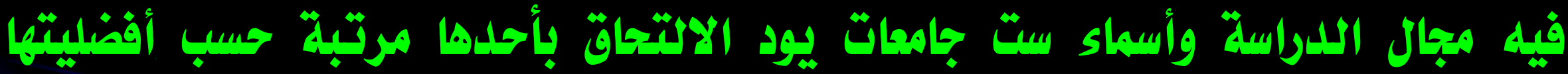

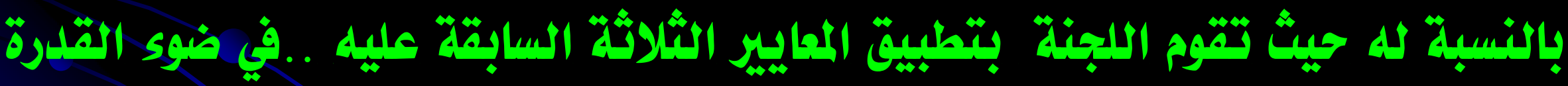
الاستيعابية التي يجداها مجاس كل جامعة. 


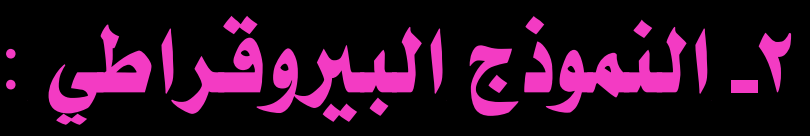

يتمد هذا النموذج على قواعد متعداة في القبول تشمل :

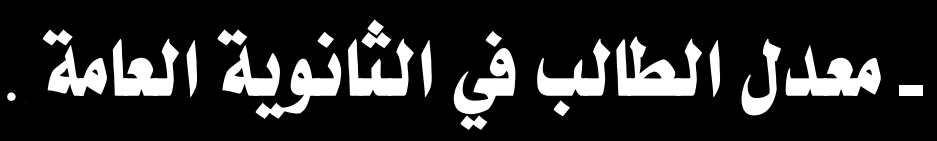

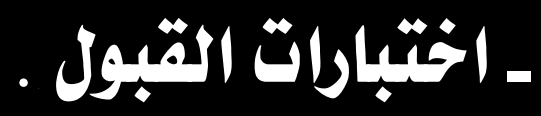

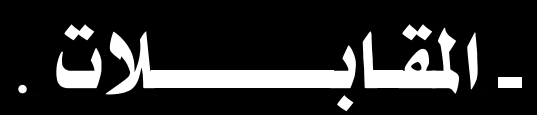

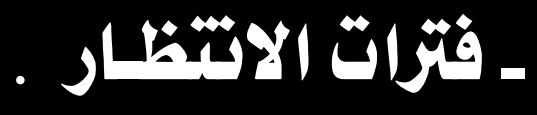

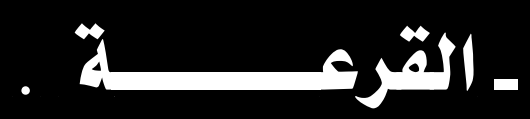

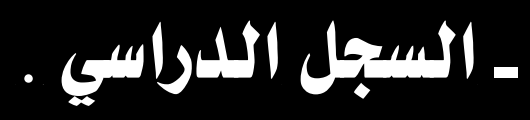
ـ حصص للحالات الصبة (معاقين ، طلبة أجاثب ......).

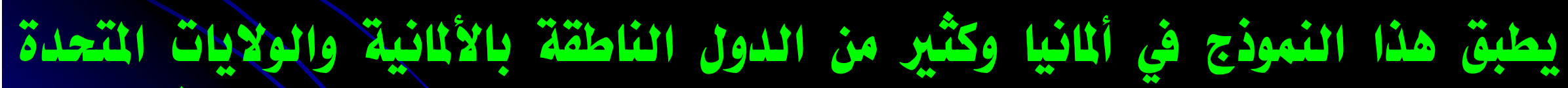

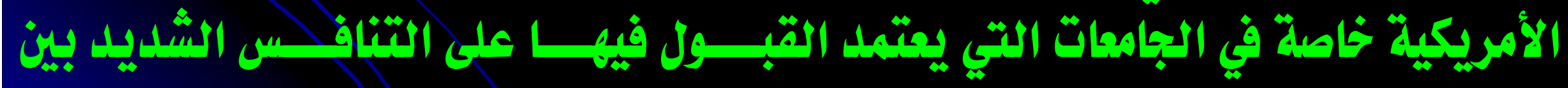
الطالاب ؛ وذأك علي الندو التالي : 
متشثل شروط القبول بهؤسات التقليم العالي بصفة عامة في المانيا فيما يلي :

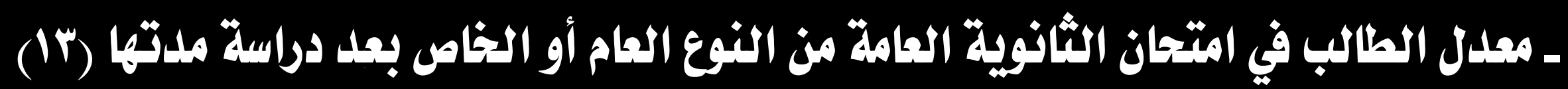

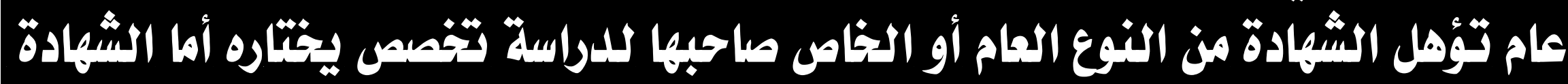

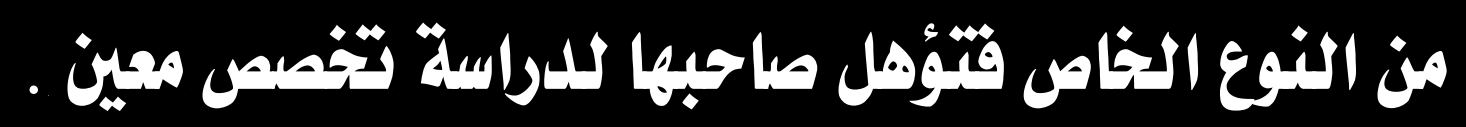

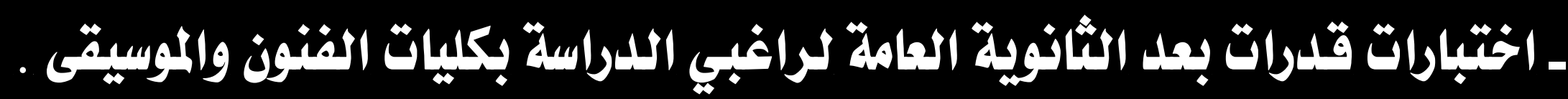

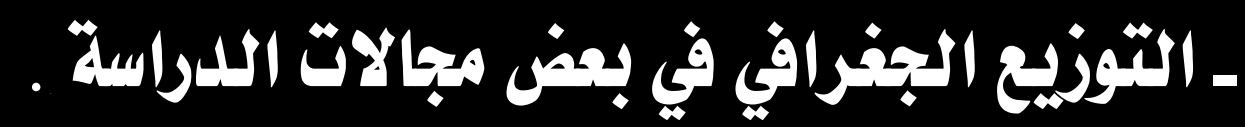

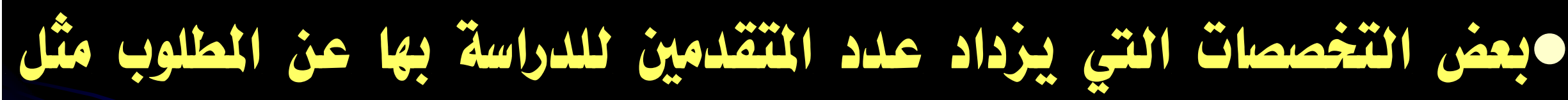

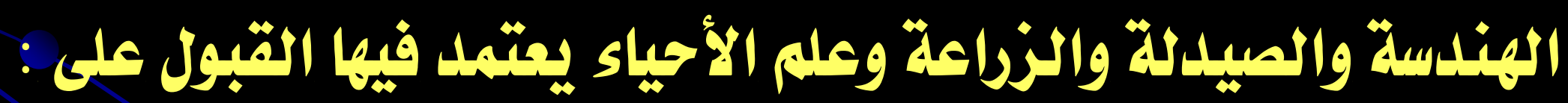

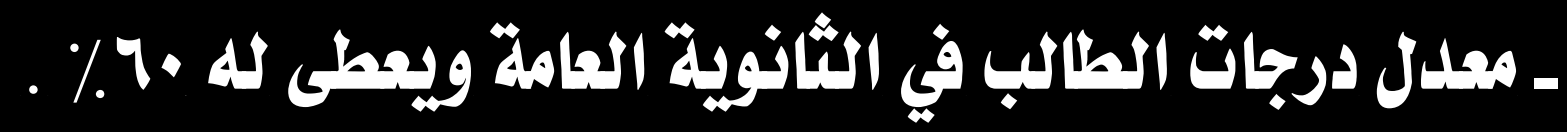

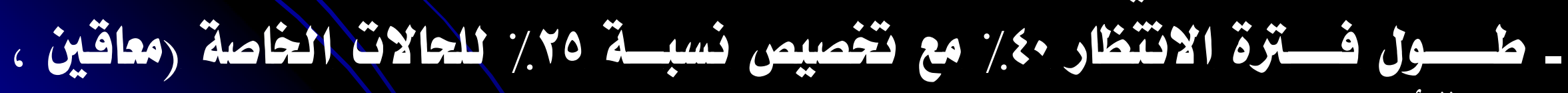

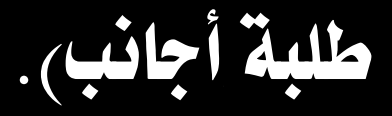


ميثم القبول في الثماع الطبي (الطب البشري وطب الأسنان والطب البيطري) عل النحو الثالي : النئي ـ • • من الأماكن لاحالات الخاصة (طلاب أجانب ، حالات صعبة .....اتخ) ـ \% \% من الأماكن على أساس القدرات 80٪ منها على أساس مجمبوع الطالب في الثانوية

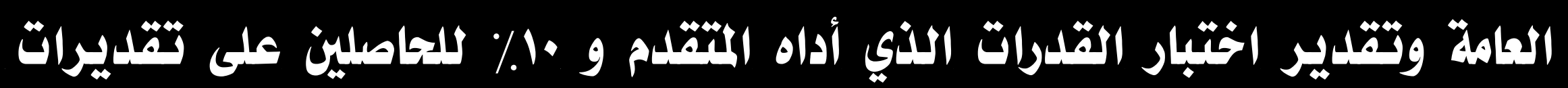
مرثفعة في الاختبار وحلده .

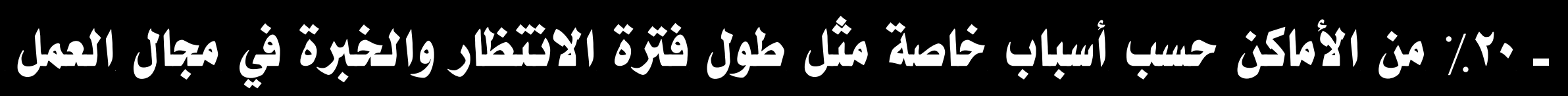

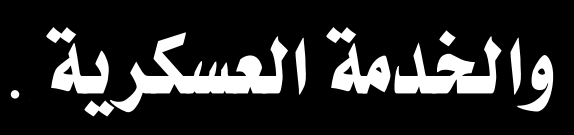

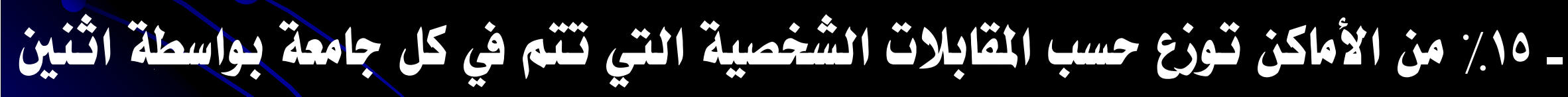
من أعضاء هيئة التدريس وإذا زاد علد الاتقدمين عن علد الأماكن يثم اختيار من

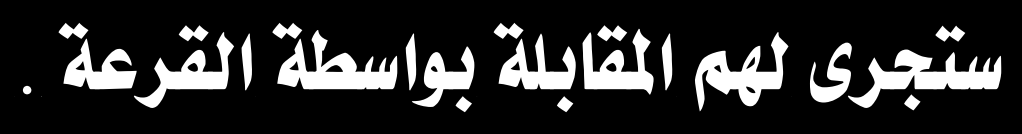




\section{بـ ـ الولايات المتحلة الأمريكية :}

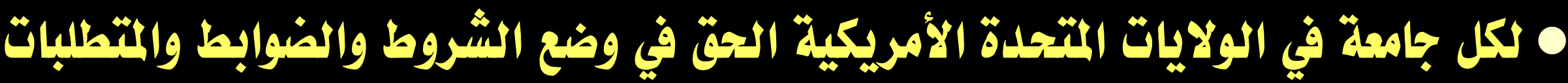

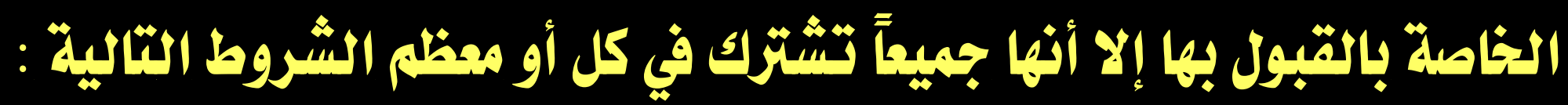
ـ اجتياز الامثحان الثهائي للدراسة الثاذوية .

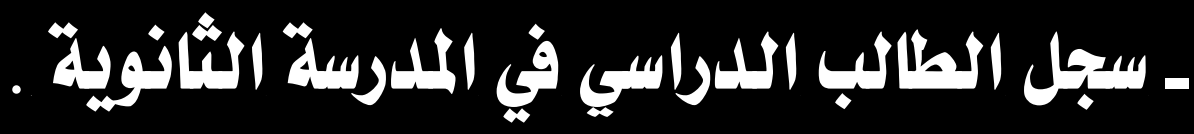
ـ الثقارير الشخضية التي تكثبها المدرسة عن الطالب . ـ اجتياز اختبارات القحصيل والاستعدادات التي تمثل بواسطة هيئتين قوميتين هما Examination Board College مجاس امثحان الثبول بالكيات Entrance "CEEB" American College Testing Program (Act) 
• وفي ضوى هذه الشروط يقسم مجلس كارنجي لدراسات سياسات التقليم العالي نماذج

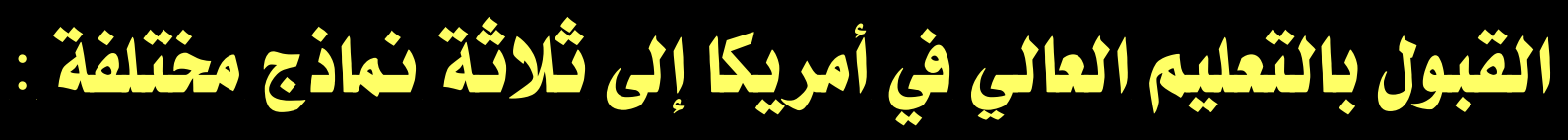

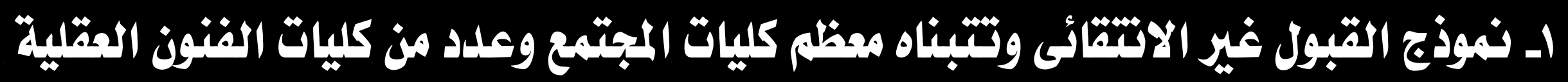

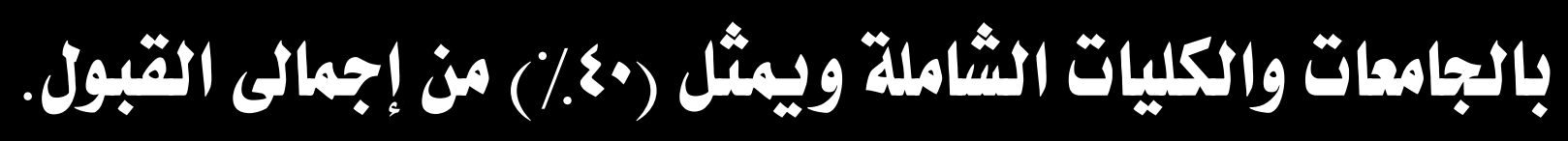

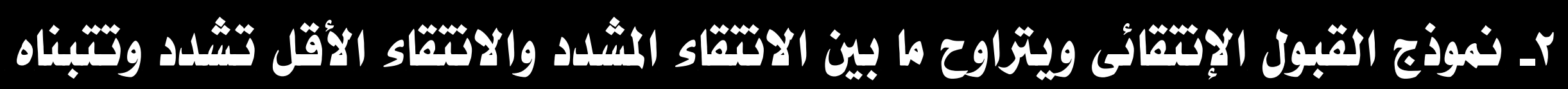

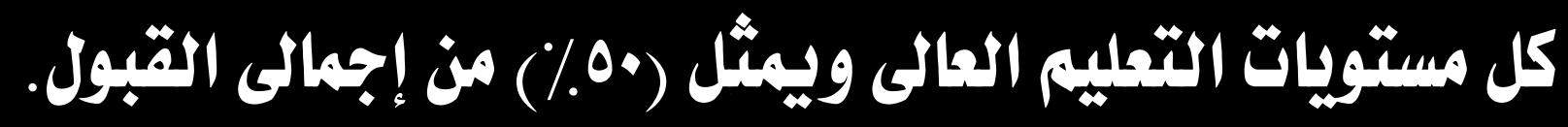

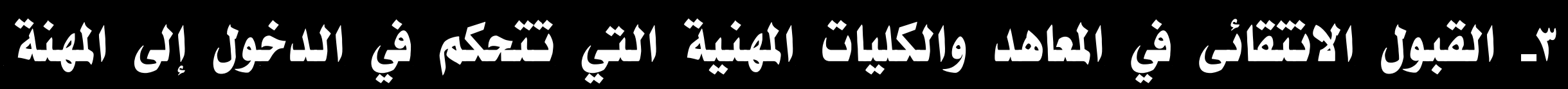
ويشل (•اء) من إجمالى القبول.

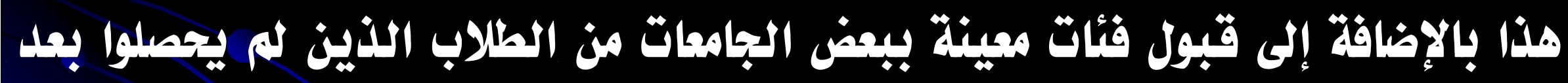

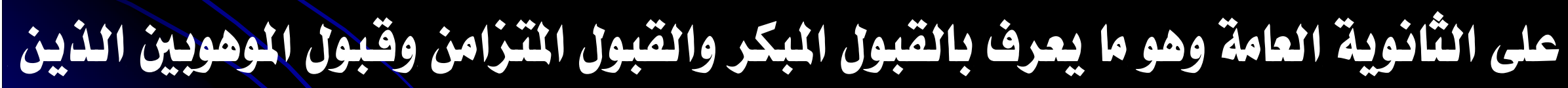

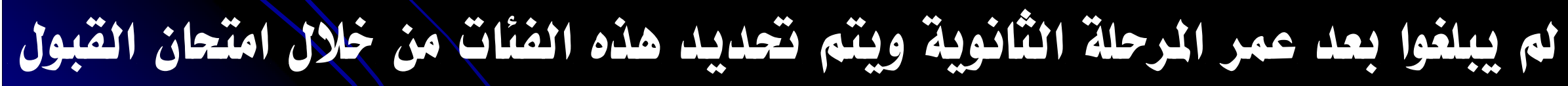
بالكليات واختبار القدرات المدربسي . 


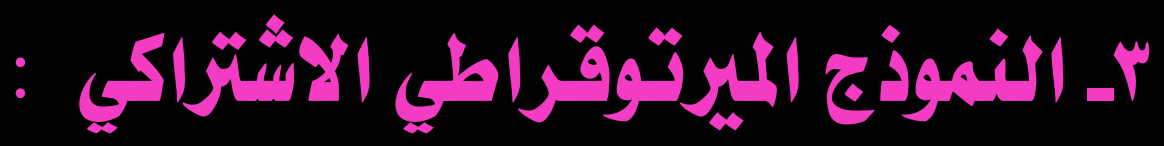

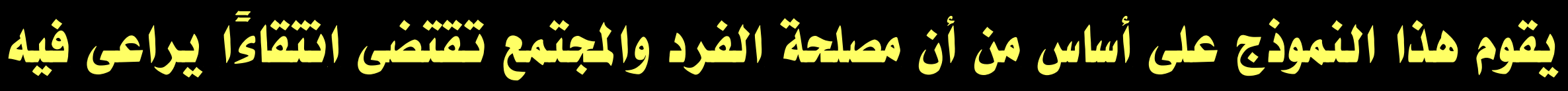

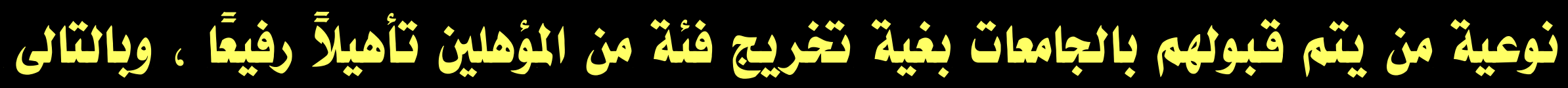
فهذا الأسلوب يؤكل على المبادقى الأساسية القالية :

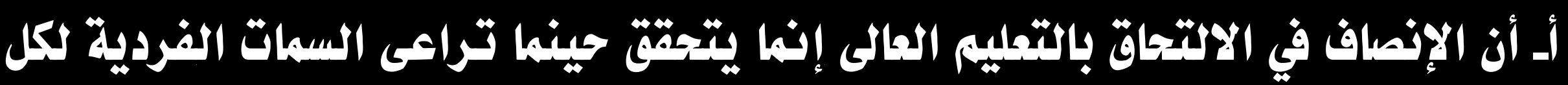

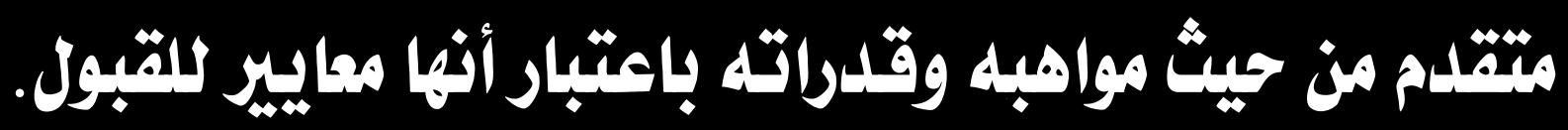

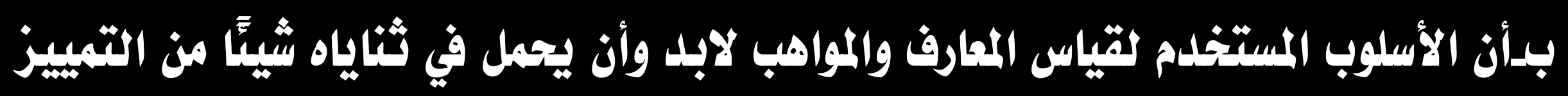
بالنسبة لأولئك الذين يتثتون بذانية اجتمامية مينة. ع- أن يكون هناك تعادل بيز عدد القبولين وأعداد الثوى البشرية المدربة القع يعتاج إليها المبتمع أى بين القبولين والخريجين. 


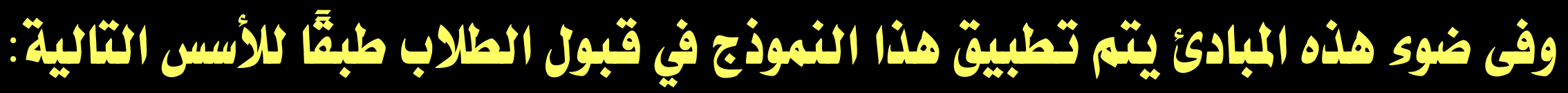

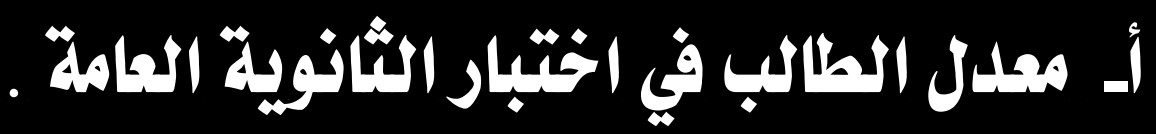

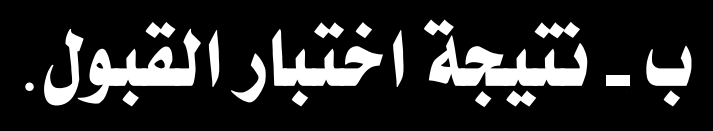
ع ـ احتياجات خطة التنية من القوى البشرية المدربة في متخلف التخصصات.

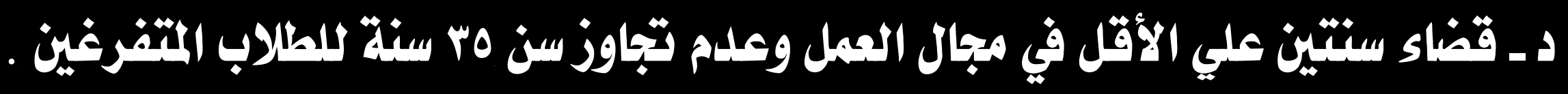

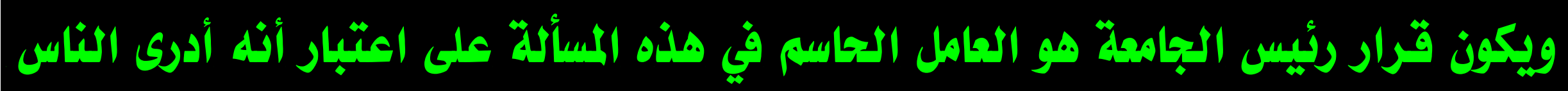

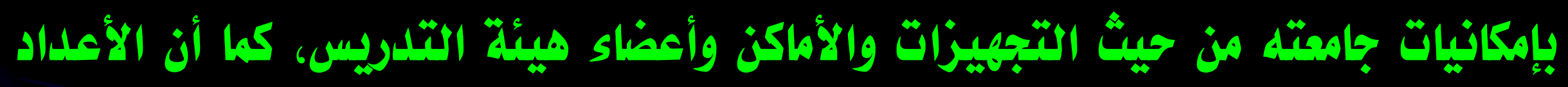

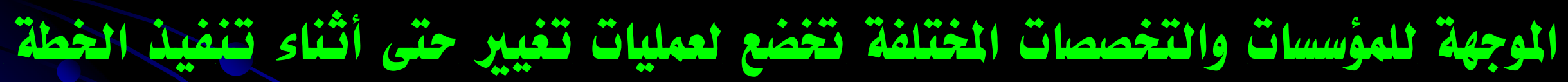

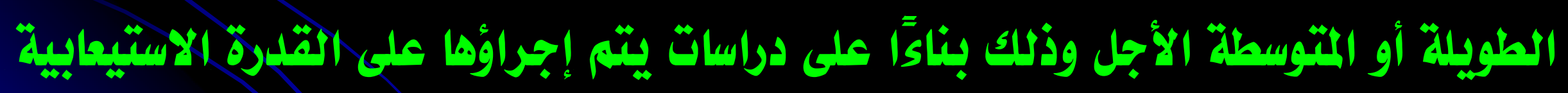

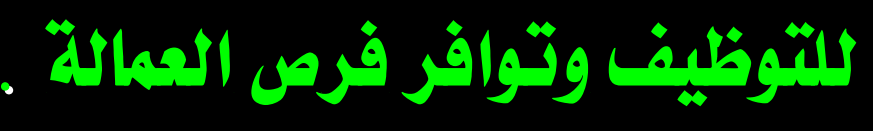




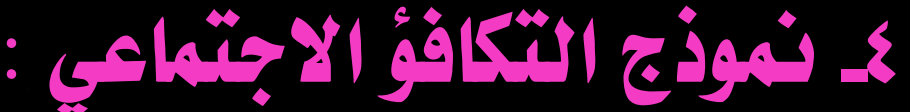

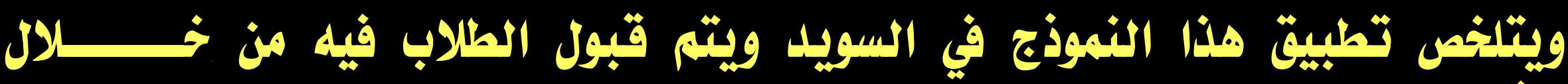
الشروط الثالية:

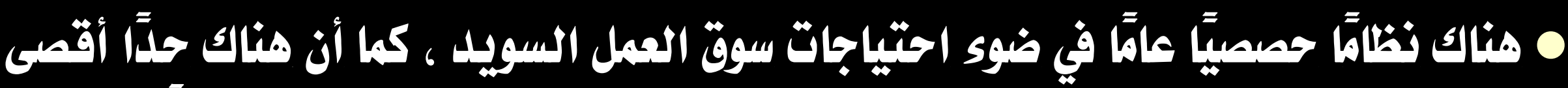

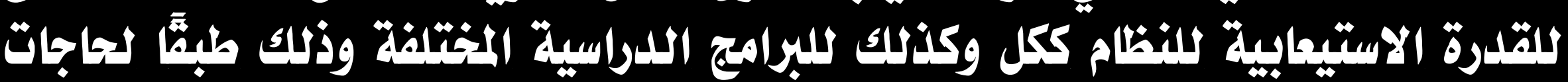

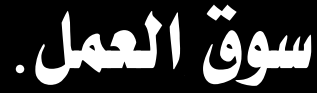

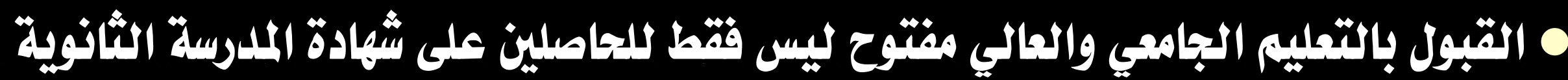

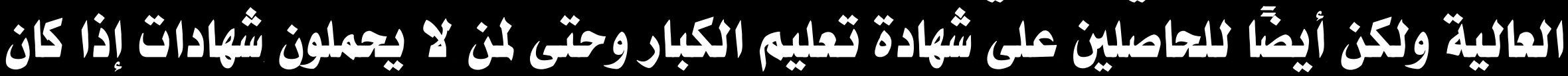

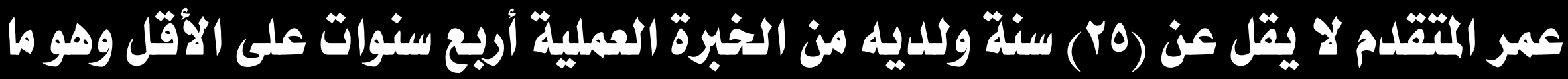

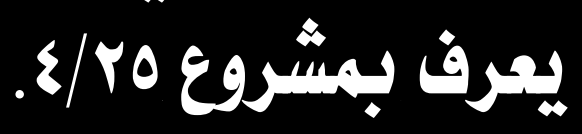

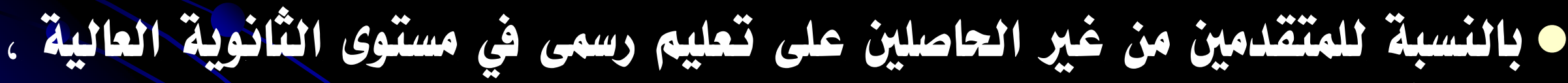

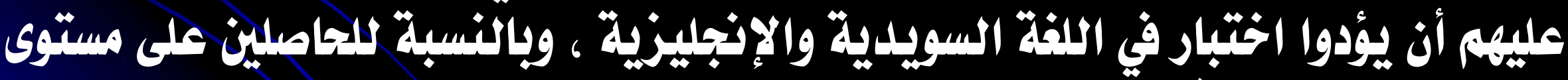

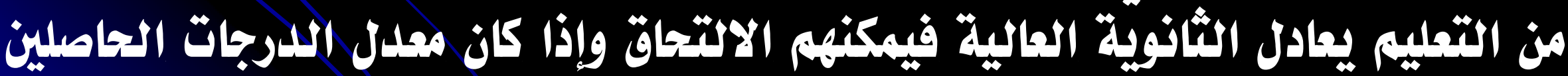

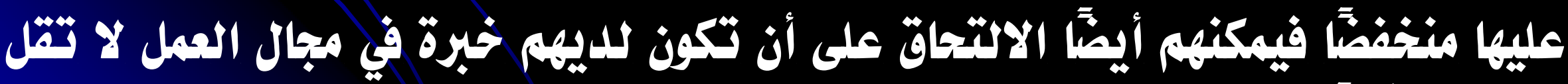
مئ (10) شهرًا. 


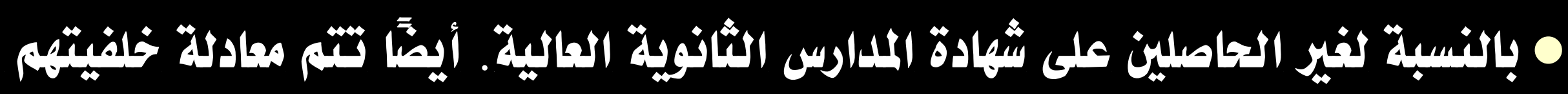

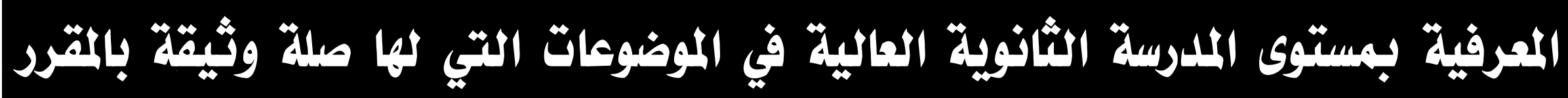

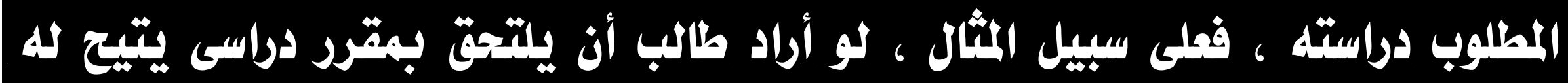
الحصول على درجة في الهندسة المدنية، يجب أن تشوافر للديه خلفية مصرفية في الرياضيات والفيزياء والكيهياء وفى مستوى خريج المدرسة الثانوية العالية في مواد مثل التكثولوجيا والرياضيات والملوم الطبيسية. 


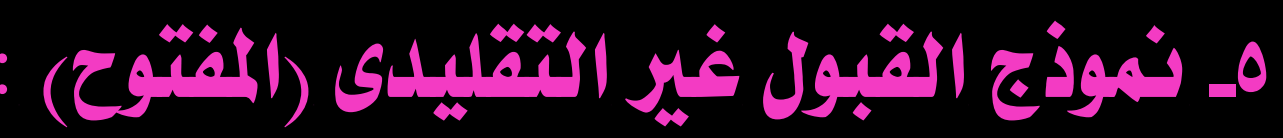

ويمكن إجمال الغطوط العامة المئزة لهبا النئام على الندو الثالى :

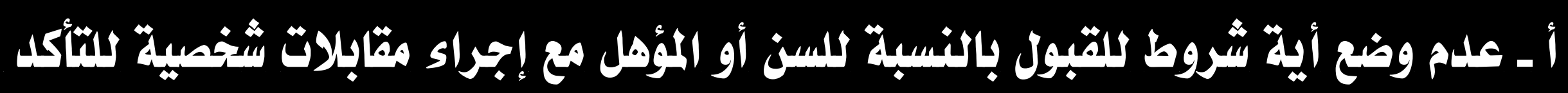
من قدرات واستعدادات المتثلدين.

ب - إجراء اختبار موحد خاص بالمتقدمين الكبار كبليل لاختبار إثمام الدراسة الثانوية

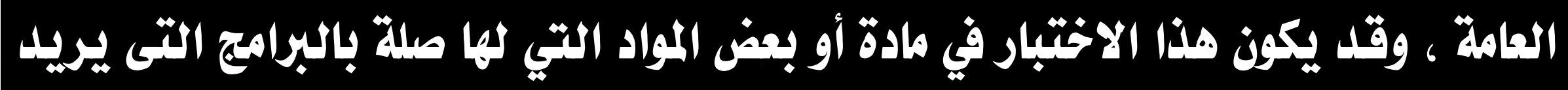
الأطالب التشبيل فينها. جـ ـ الثغاذ الخبرة المملية كبليل لشروط القبول مع إجراء بعض الاختبارات الشخصية والقحريرية القصيرة والتي تهلث إلى قياس قدرات التقدمين على الاستمرار في الدراسة

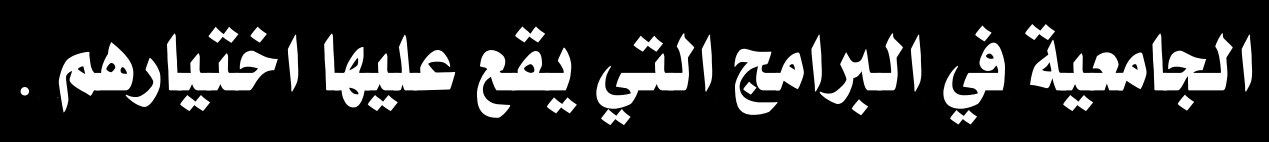




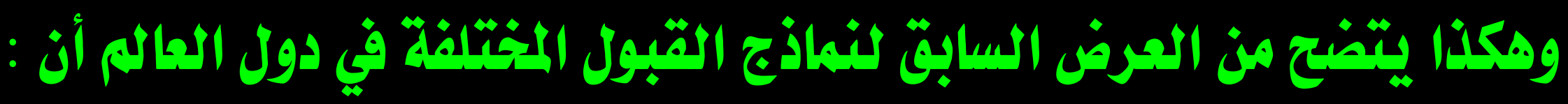

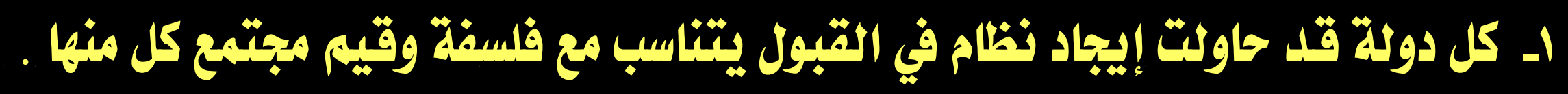

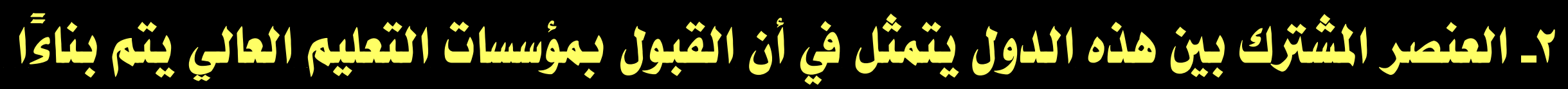

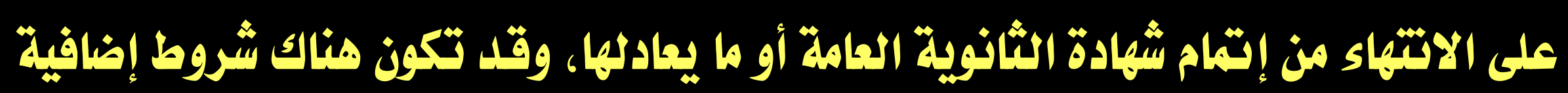

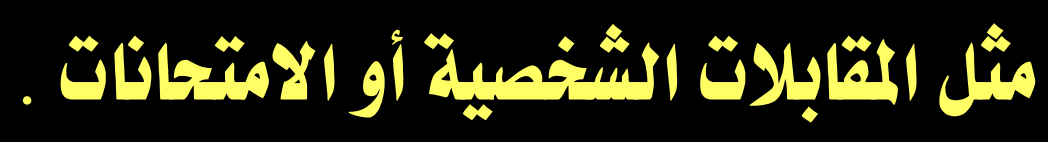

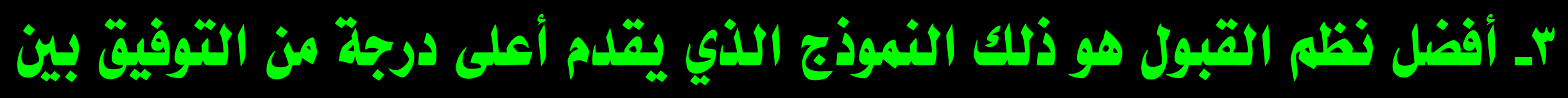

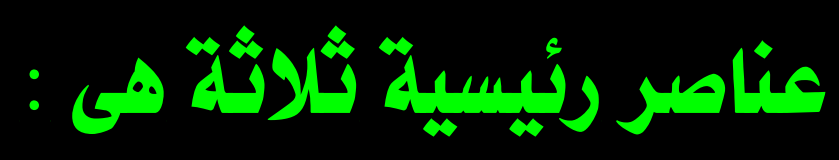
أ ـ رغبات الطالاب وميولهم واستعداداتهم وقدراتهه . بـ احثياجات سوق العمل من القوى العاملة المدربة .

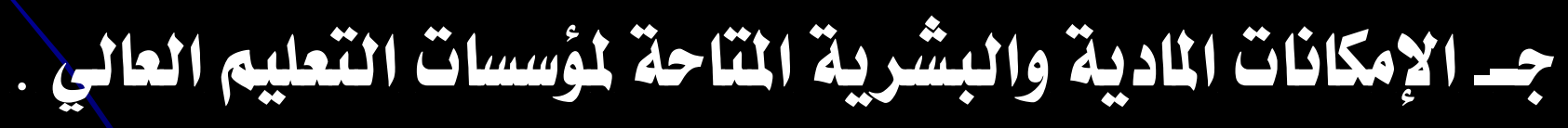




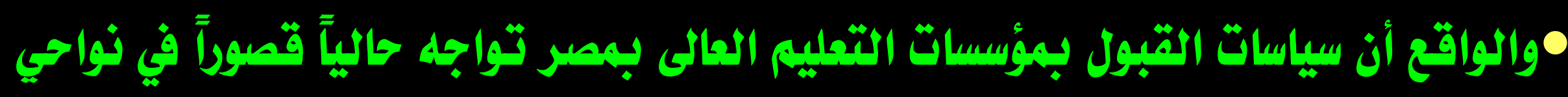

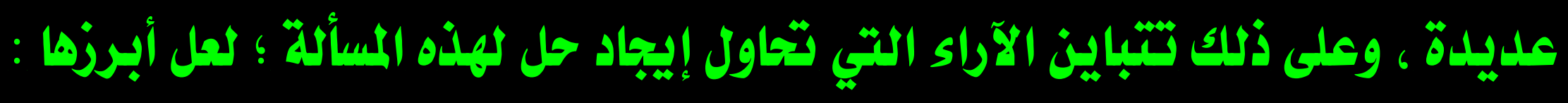
- ت تأييد البعض لفكرة إعادة النظطر في مجانية التقليم بصفة عامة والعالى بصفة خاصة. - تأكيد البغض على ضرورة الربط بين التقليم العالى وحاجات سوق العمل.

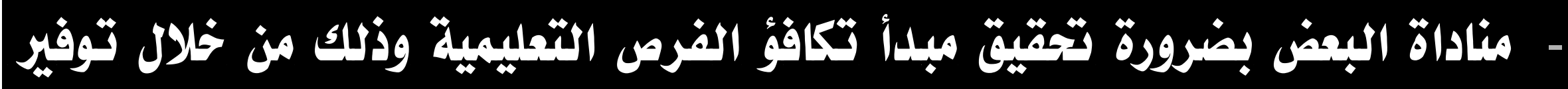

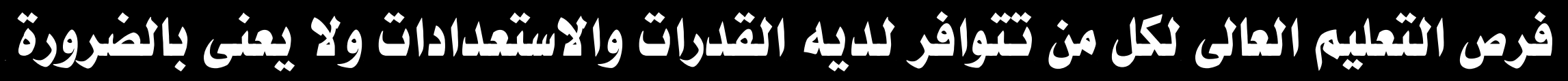

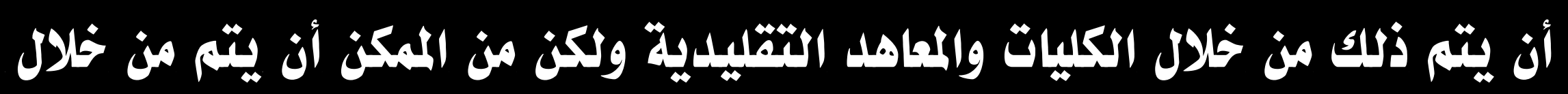

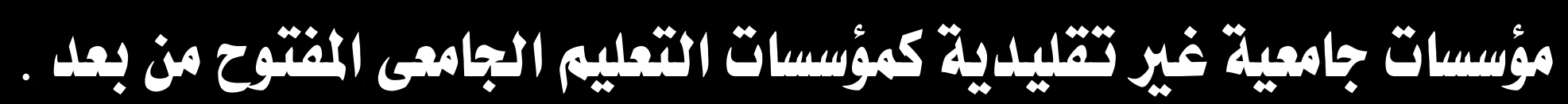

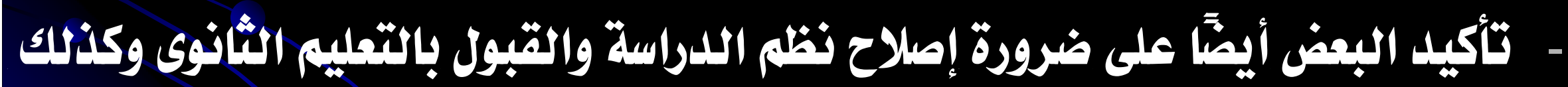

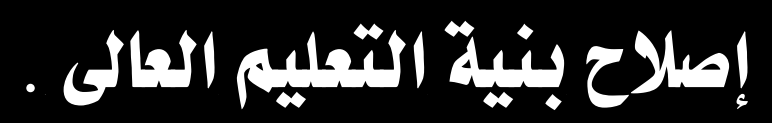


وفى ضوك هذه الآراء المتباينة وتبارب الدول الأخرى في هذا الشأن

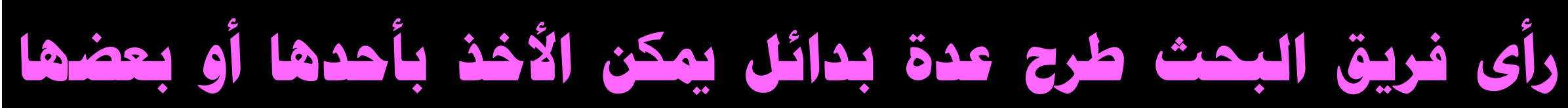

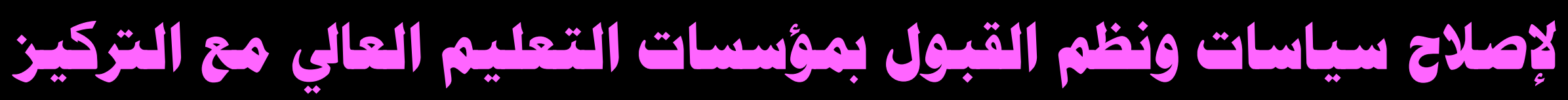
عالى اقتراج بديل وعرض لمزايا وعيوب تطبيقه. 


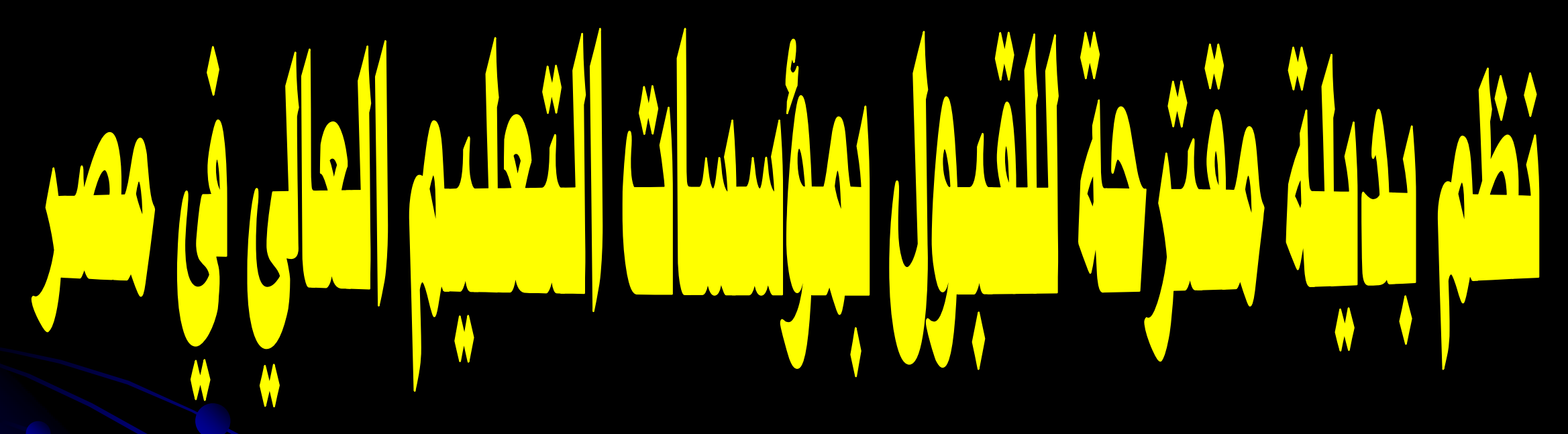




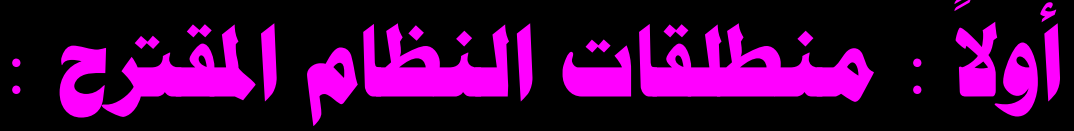

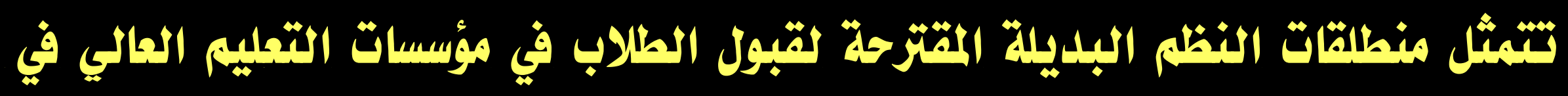
مصر فيعا يلي :

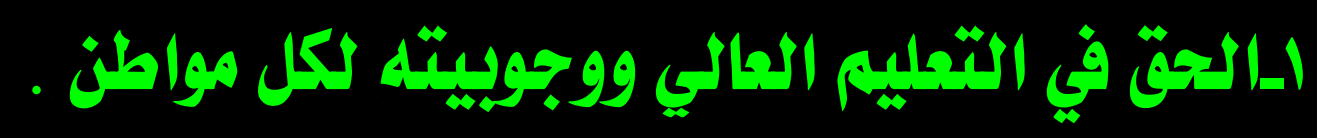
rـ القبول ينبفي أن يكمن وفق الاستيقاقات والجدارة .

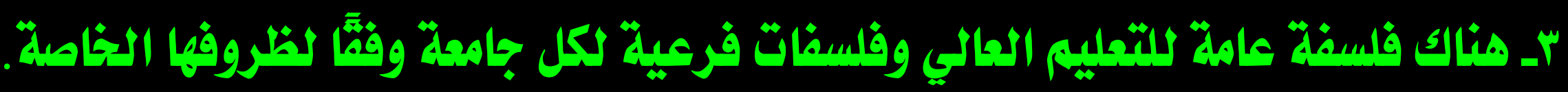

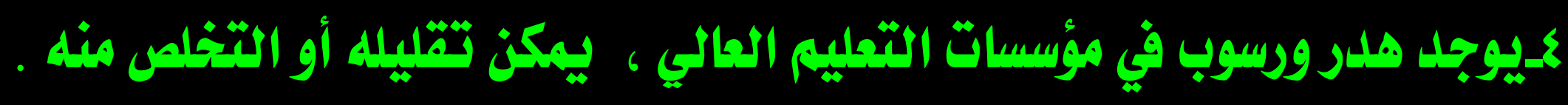

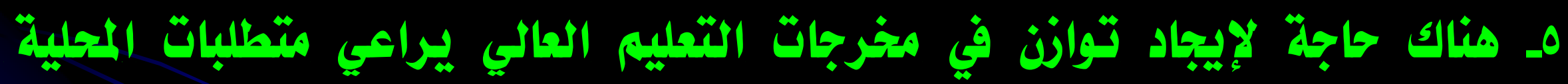

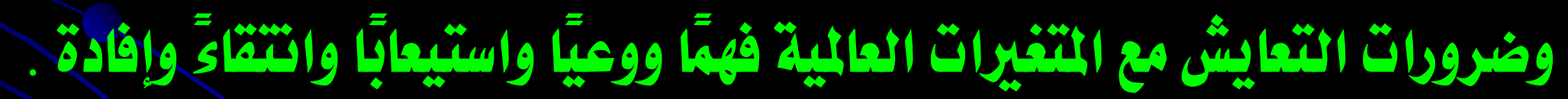

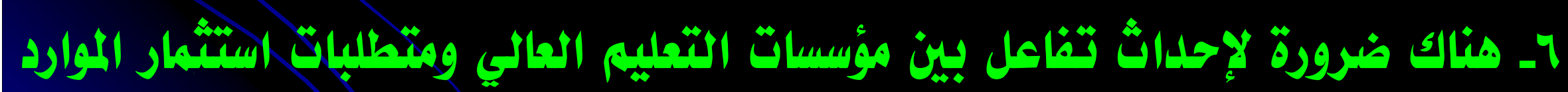

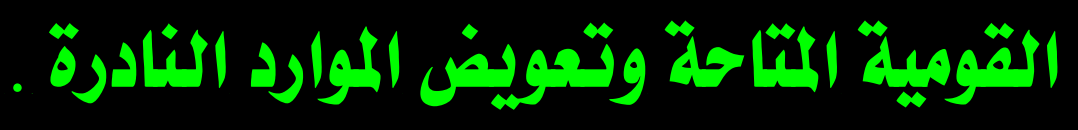




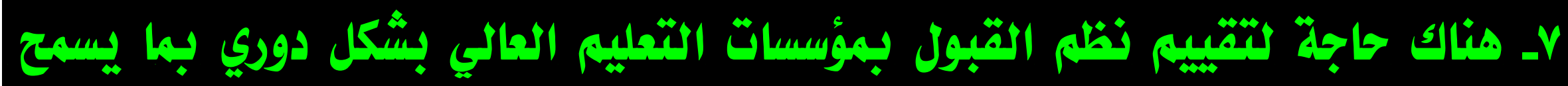

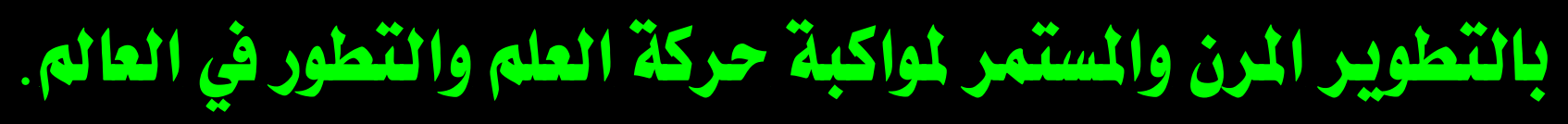

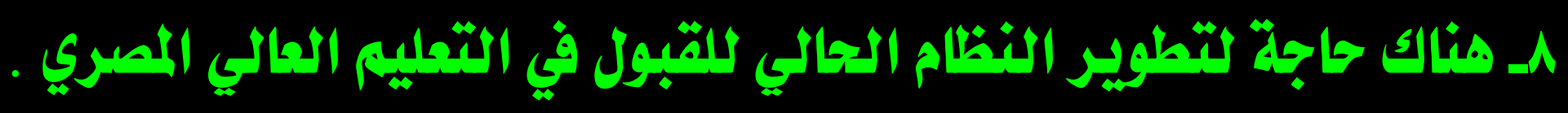

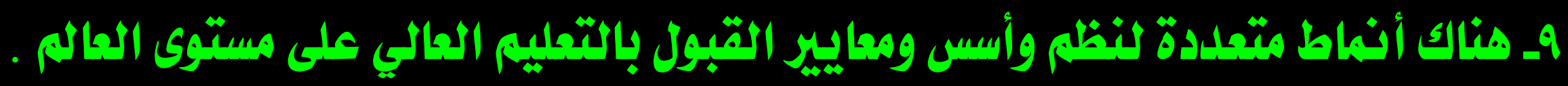

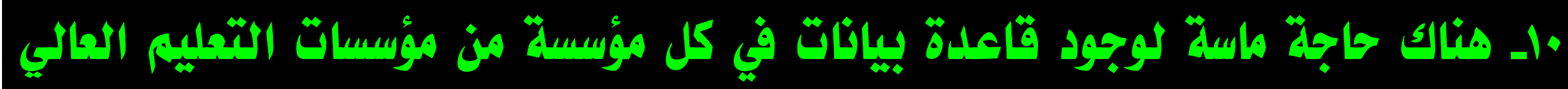
تساعد علي تيسير تبادل المعلوهات وإجراء التطولير .

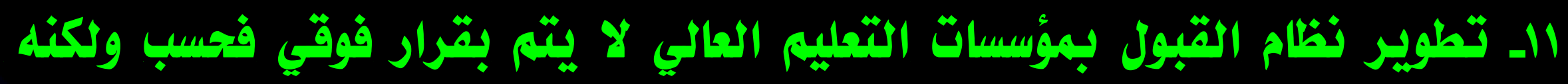

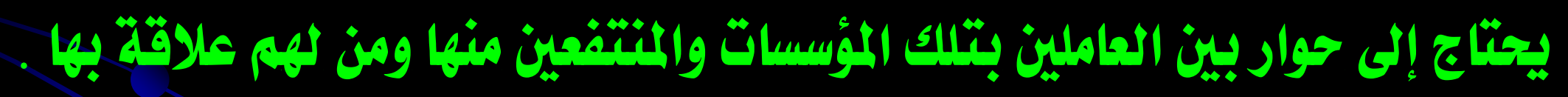

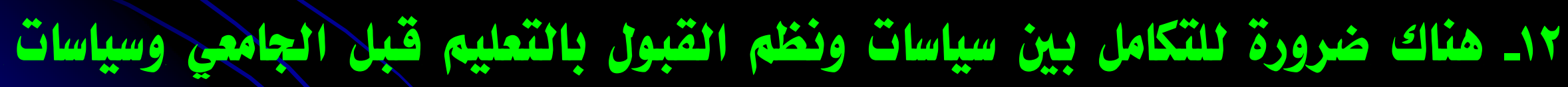
ونتم القبول بالثميم المالي . 


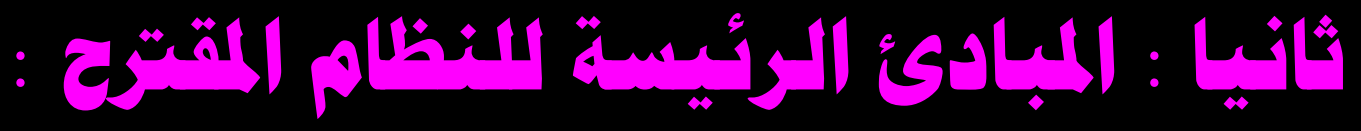

\section{تشثل المبادئ الرئيسية التي تككم عمل النهوذج المقترح فيبا يلى :}

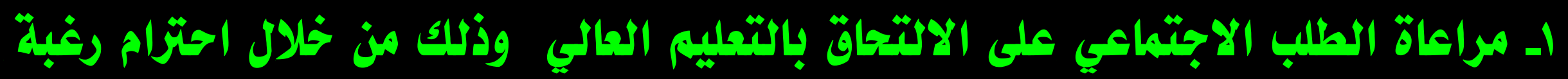
الطالب وقلدراته واستشداداته للدراسة الجامعية.

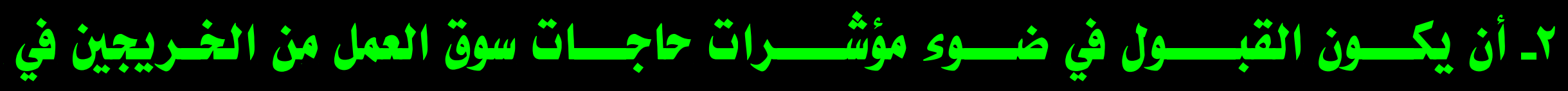
التغصيسات الإختلة.

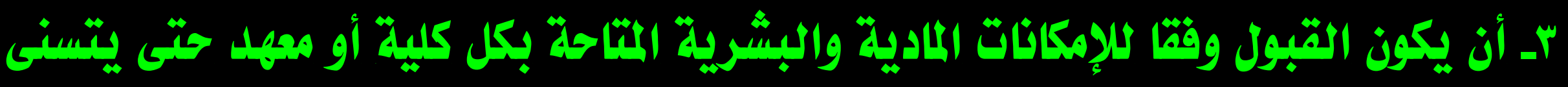

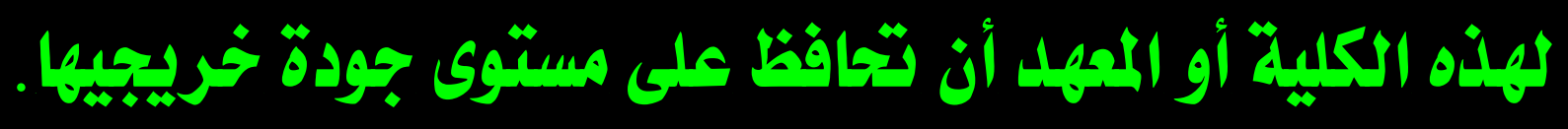

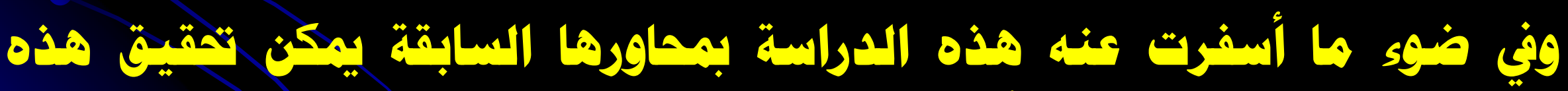

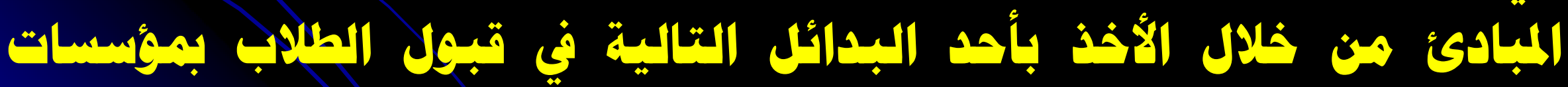

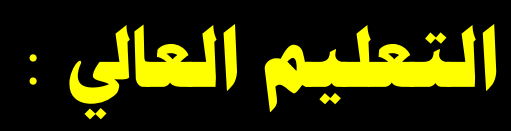


يكون قبول الطالاب بهؤسات التمليم العالي المكوبية والغخاصة في ضوك هذا البلديل علي

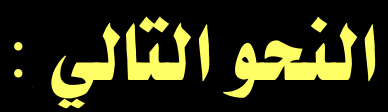

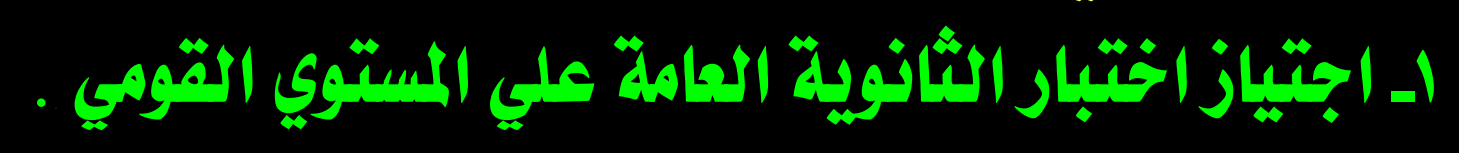

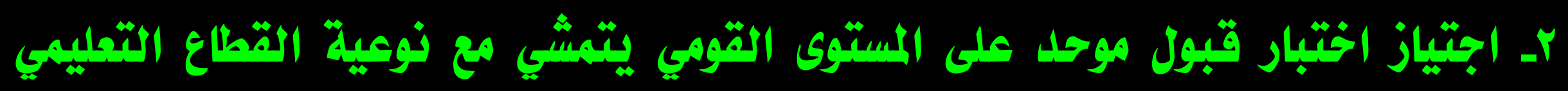

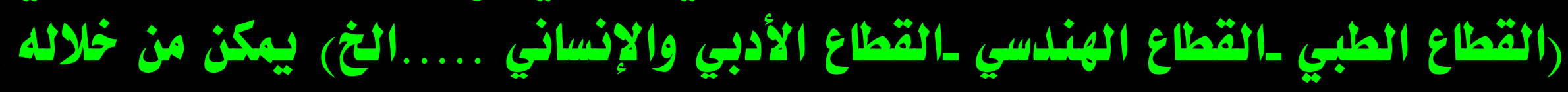

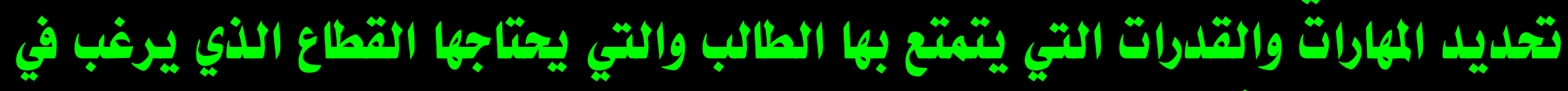

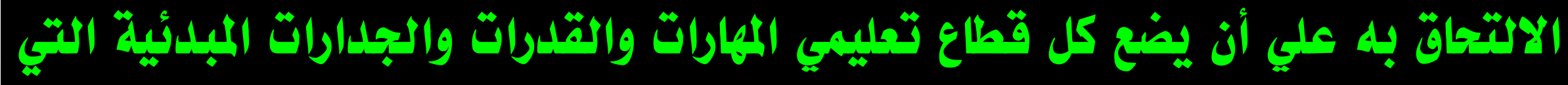

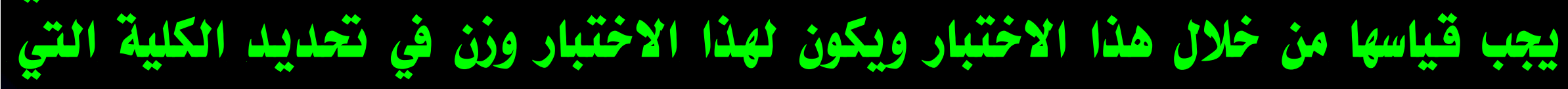

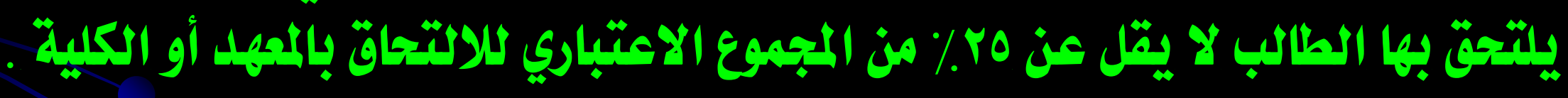

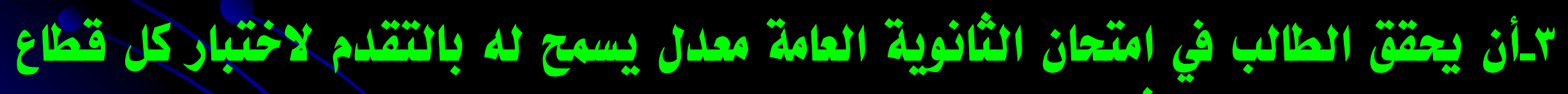

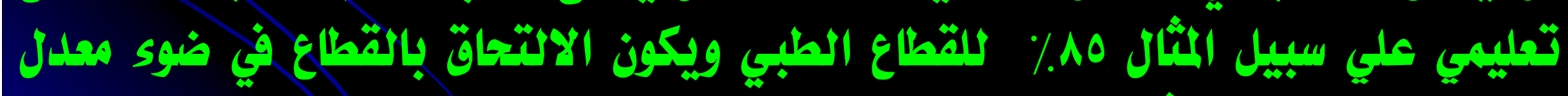

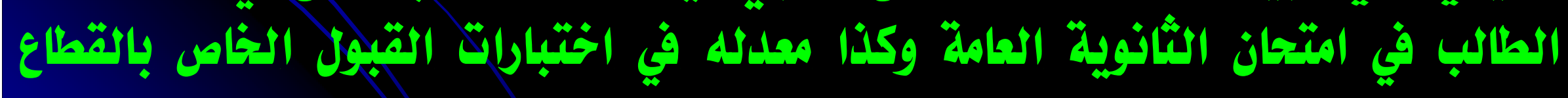

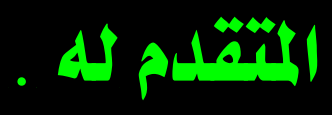

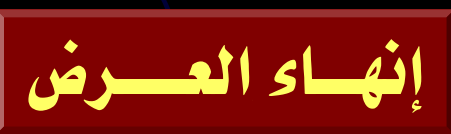




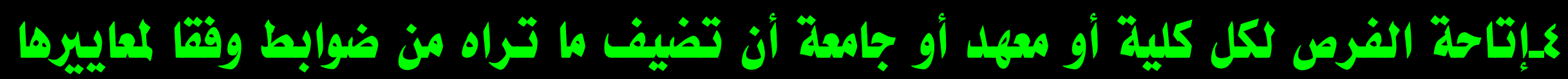

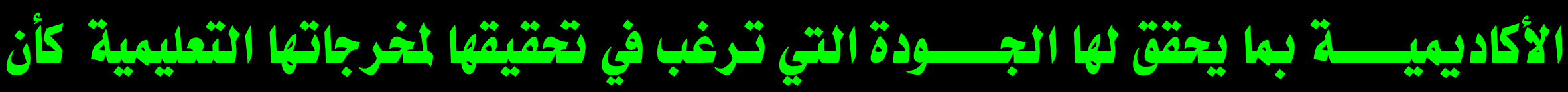

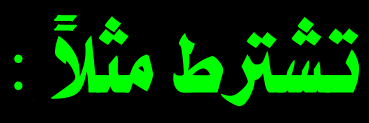

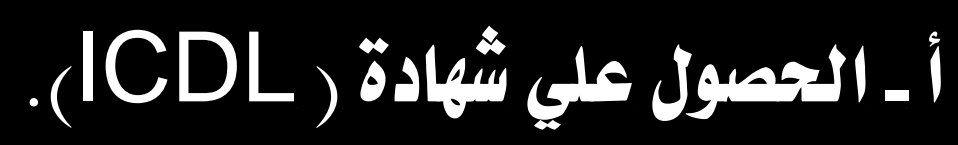

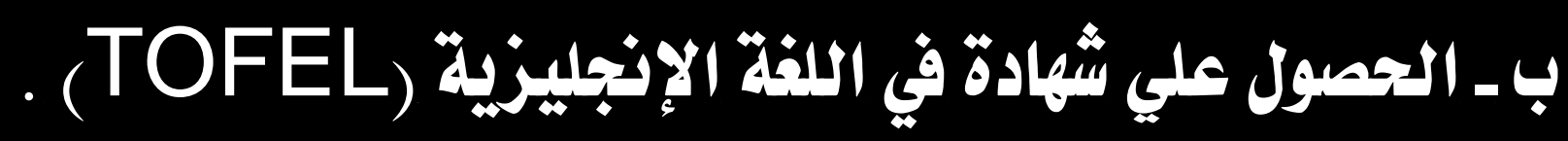

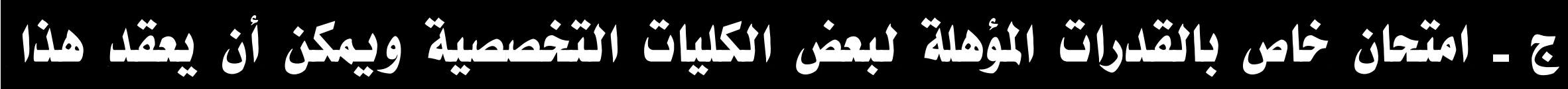

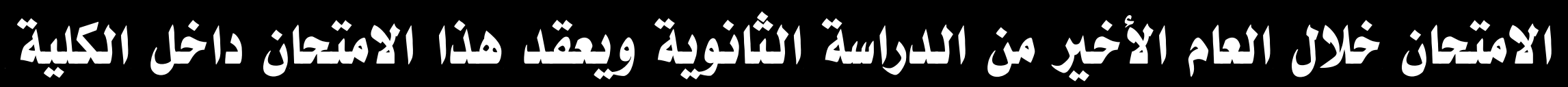

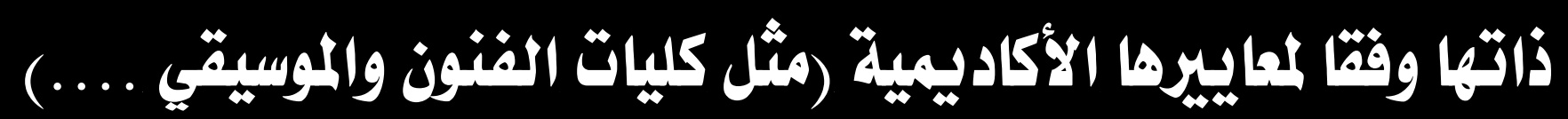

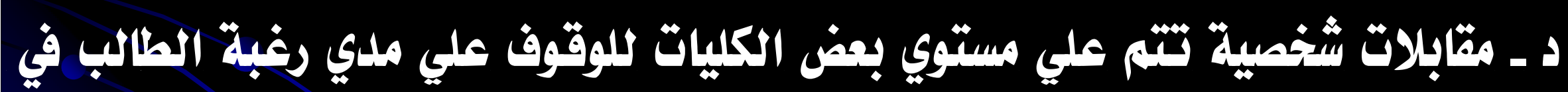

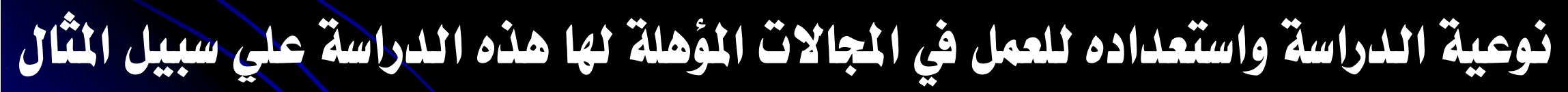

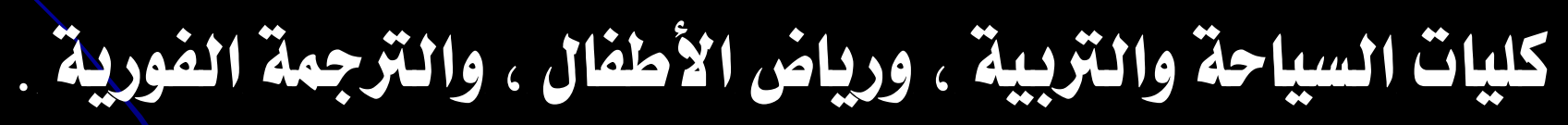




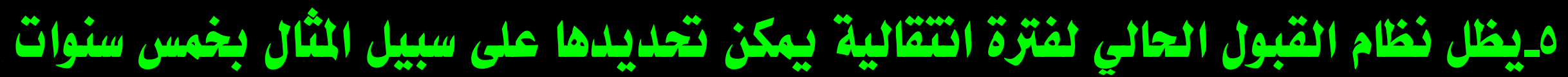

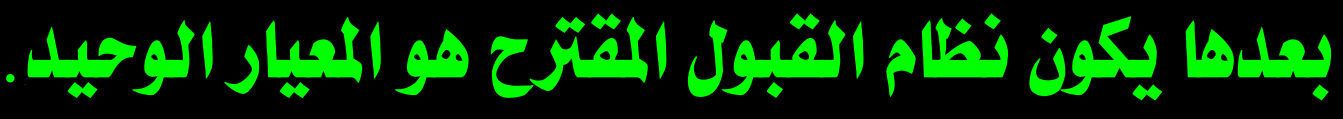

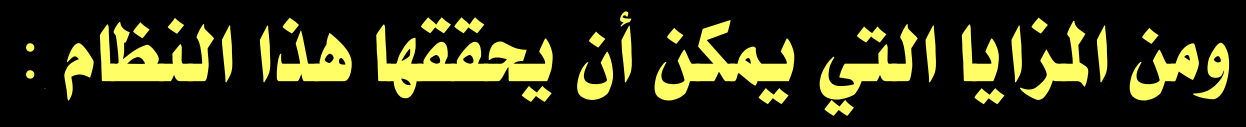

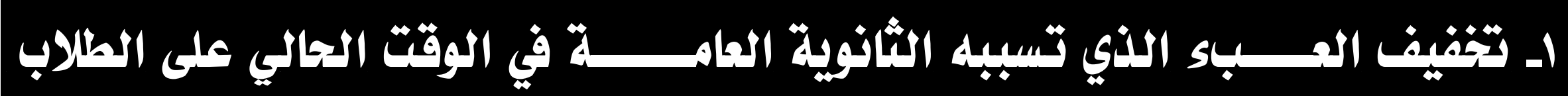

$$
\text { وأولياء الأمور }
$$

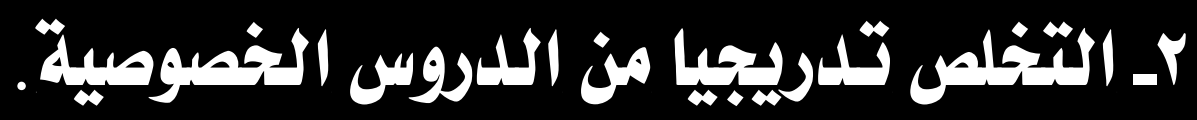

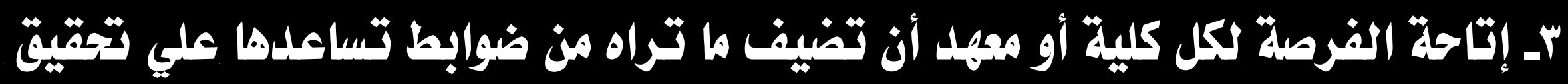

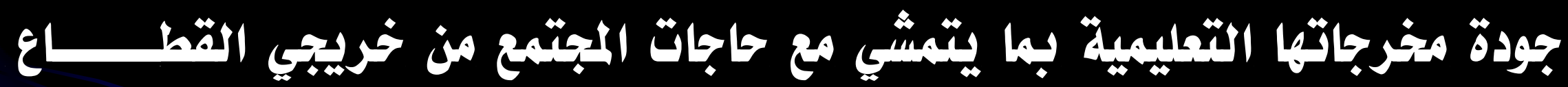

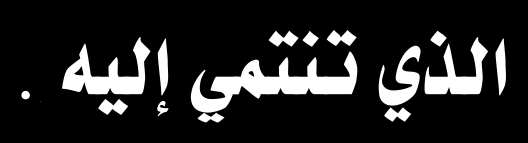

كـ مراعاة رغبات وقدرات الطالاب في عملية القبول بما يتثق وطبيعة الداراسة المشلابلة

في القطاعات المختلة.

$$
\text { إنهاء العــرض }
$$




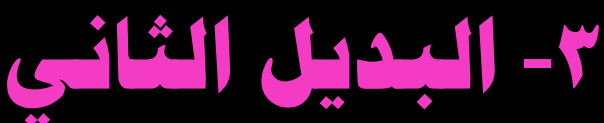

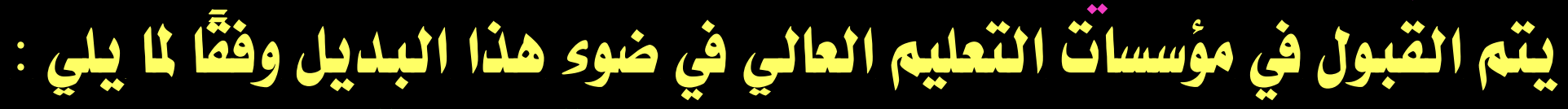

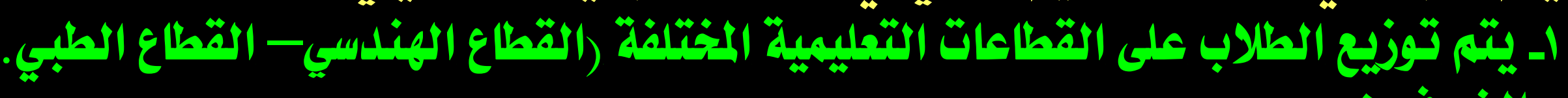

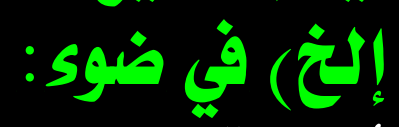

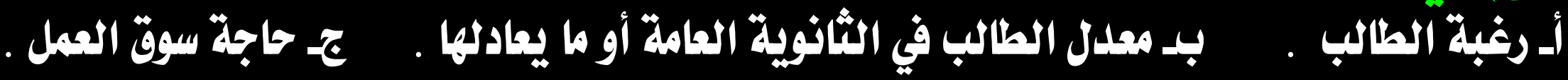

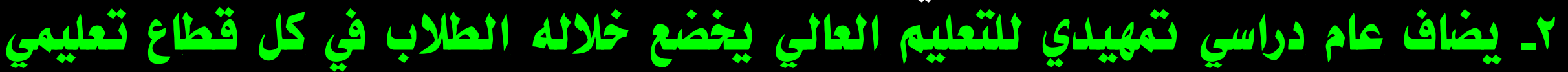

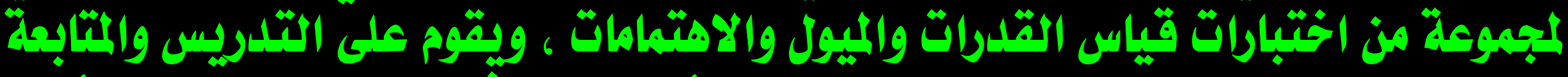

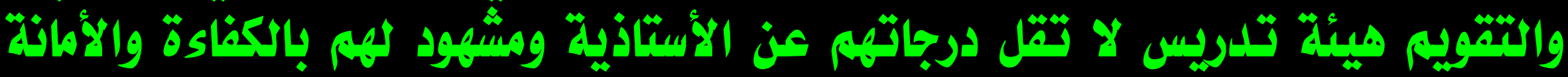

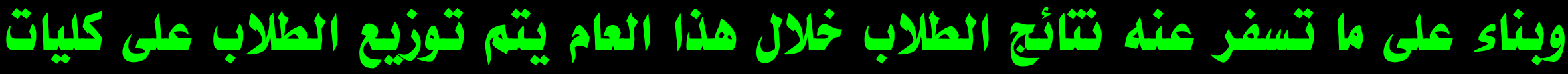

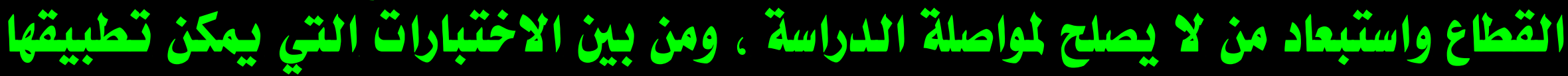

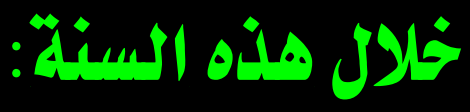

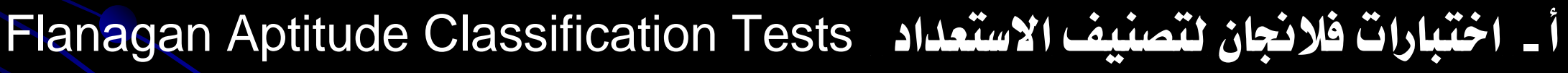

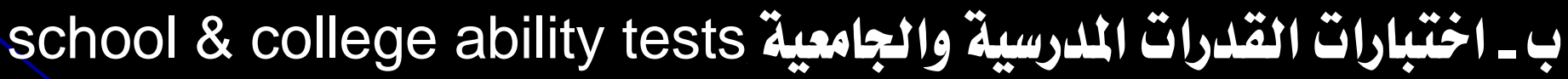

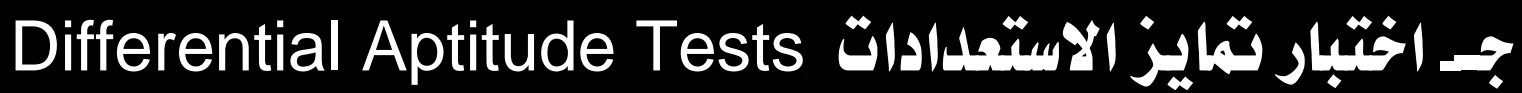

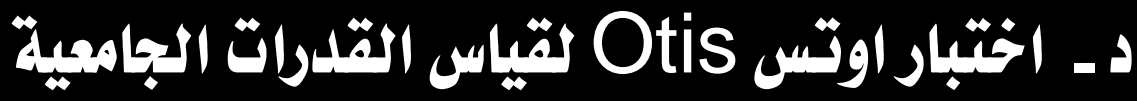

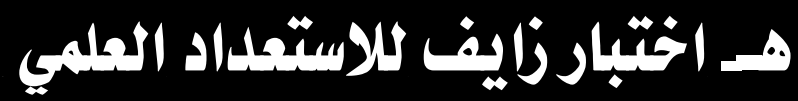




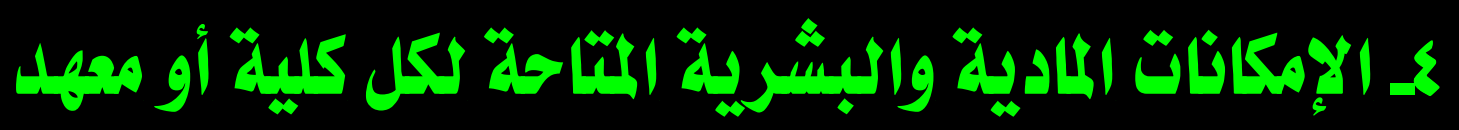

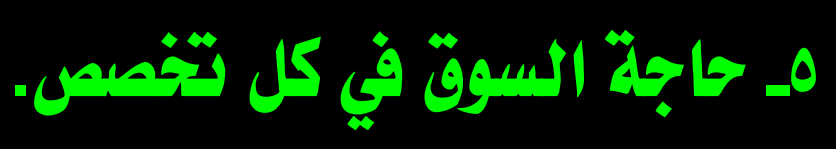

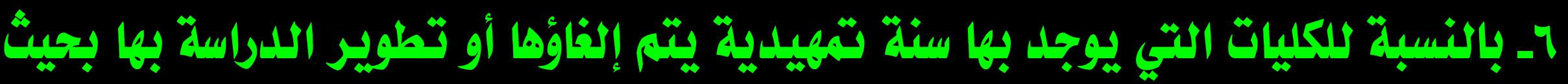

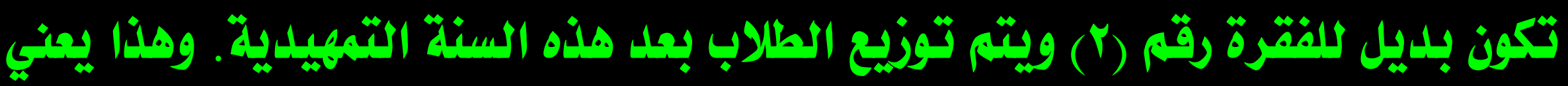

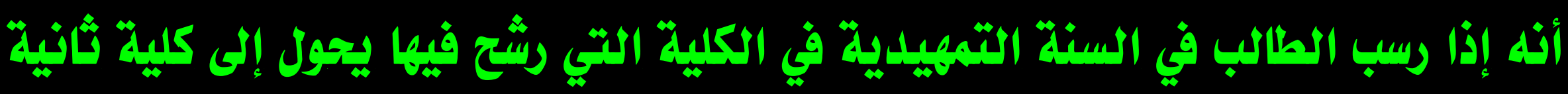

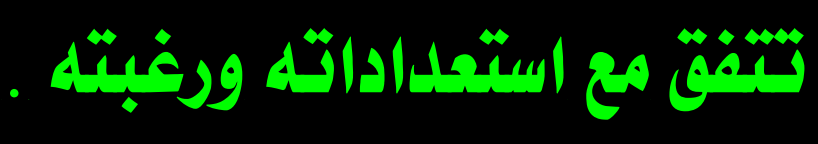

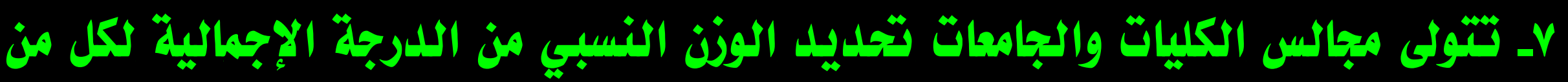

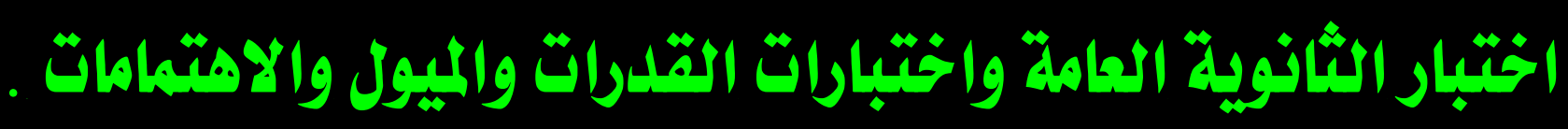


وقلد يجثق هذا البلديل الإيجابيات التالية :

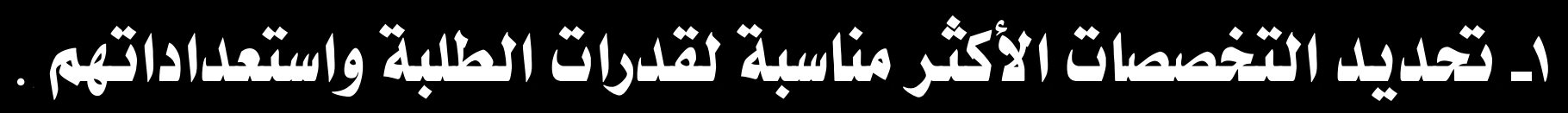

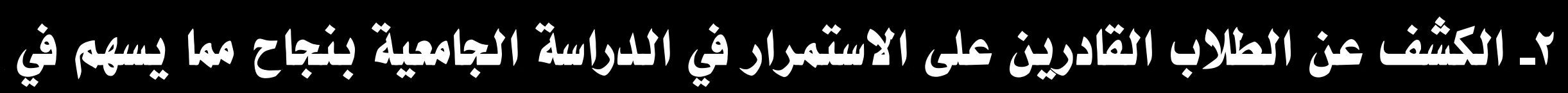

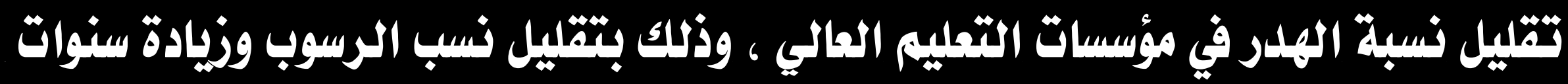
الدراسة بتحويل الطالاب إلي التخصصات التي تثناسب مع استثداداتهبه .

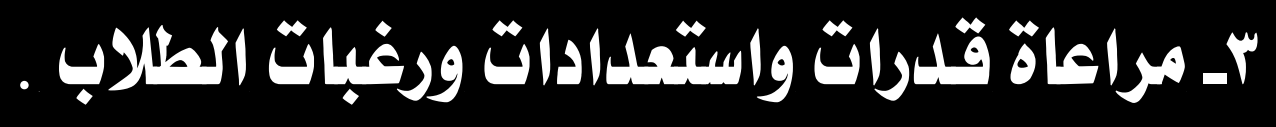

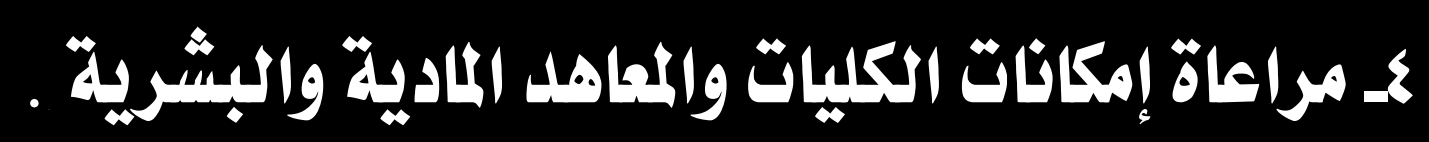
هـ مراعاة متطلبات سوق العمل من خريجي التقليم العالي في القطاعات الميتلفة .

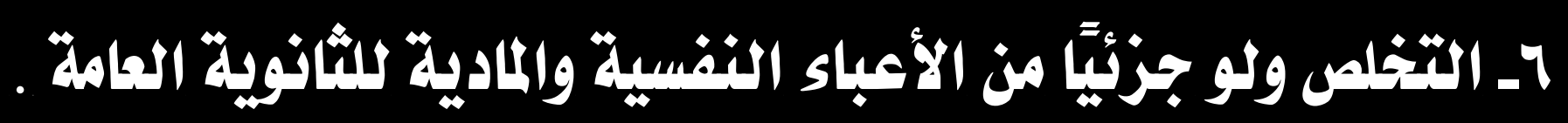

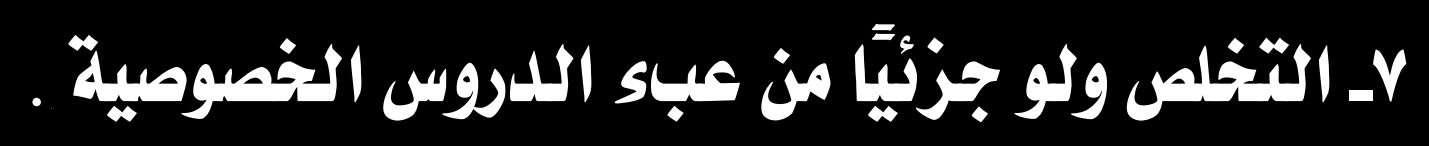




\section{إلا إنه قلد يؤخذ على هذا البلديل :}

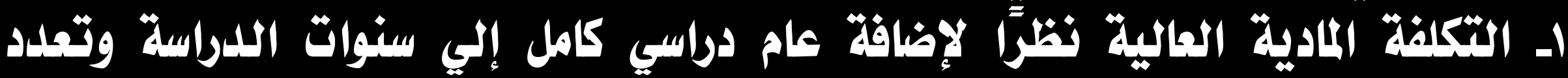

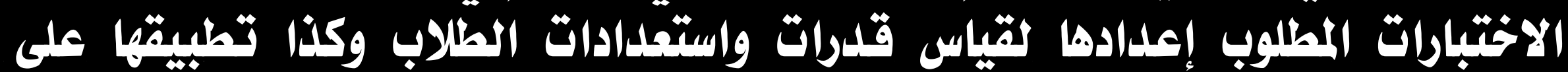

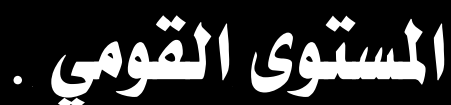

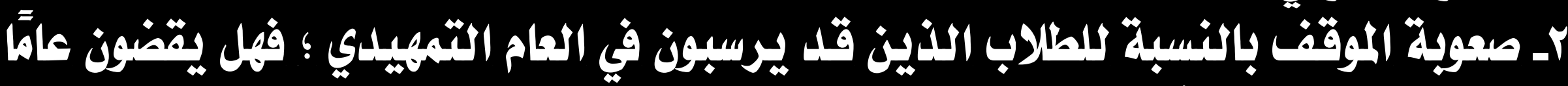

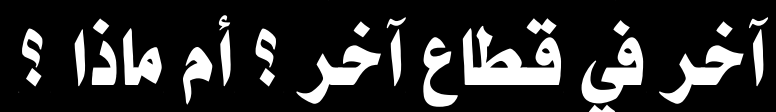

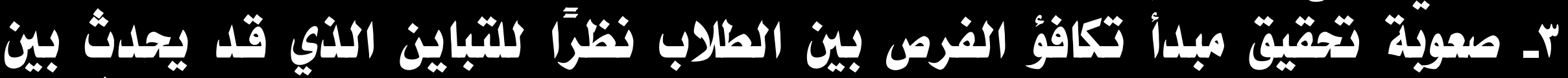

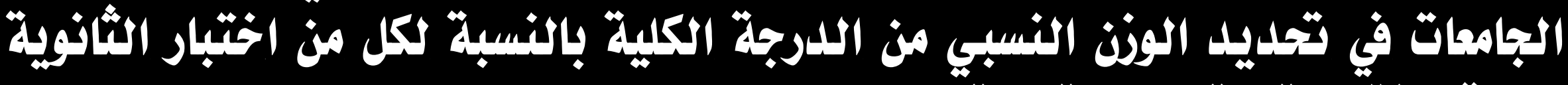

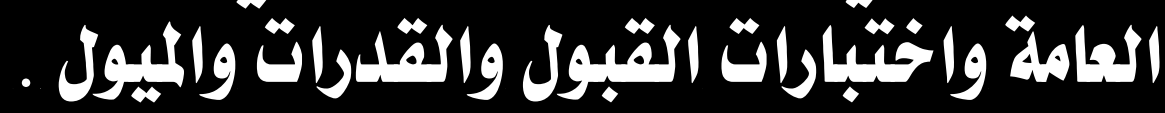

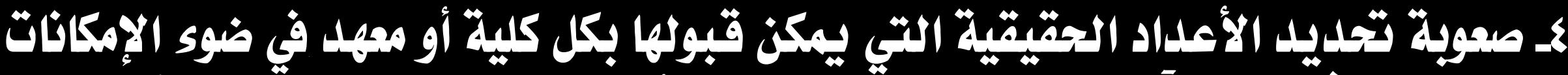

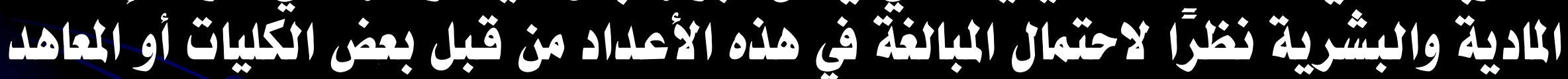
سلبًا أو إيجاًّبا.

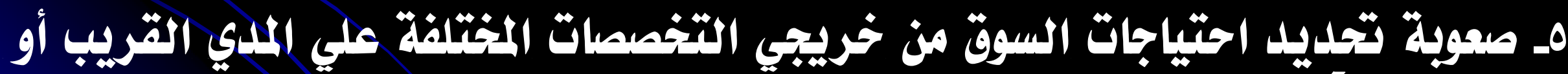

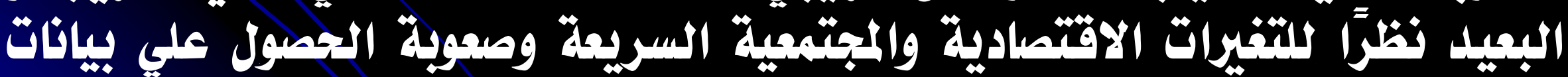

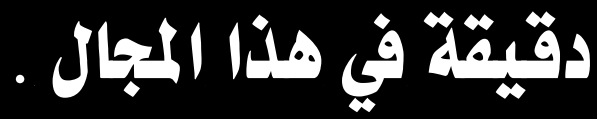




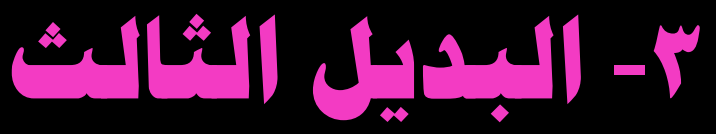

في ضوى المنطاتقات والمبادئ التي ذكرت من قبل ، يتطلب تطبيق هذا النظام إجراء علدة إصلاحات قبل التطبيق تشثل :

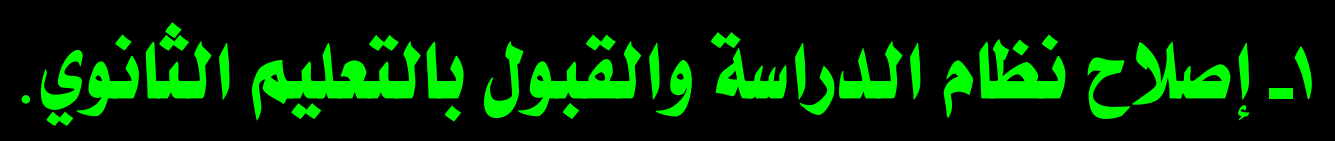

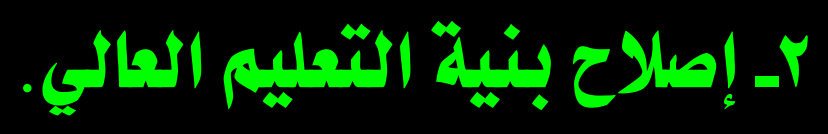

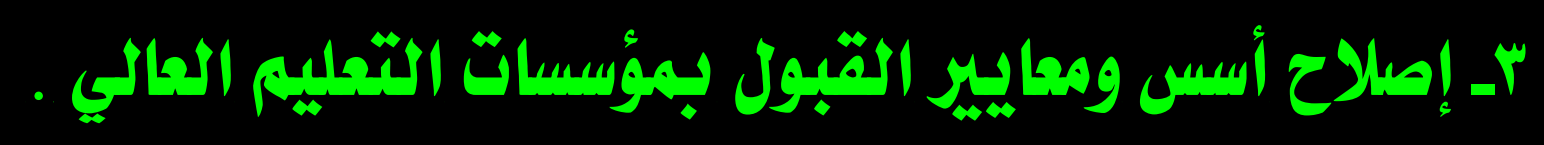
ويمكن تثناول هذه الإصلاحات بشئ من التفيل على النتو القالي : 


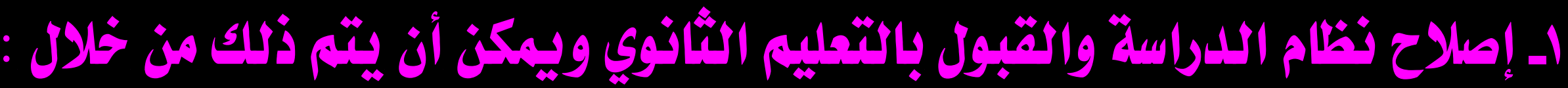

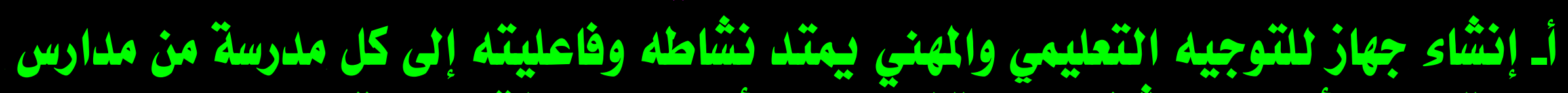

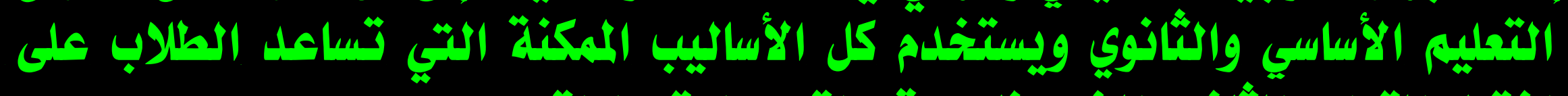

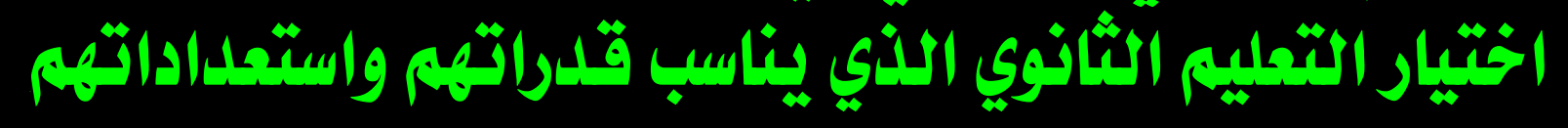

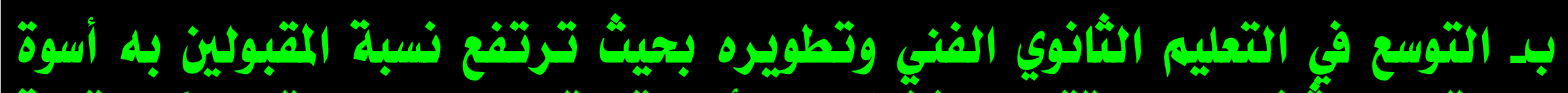

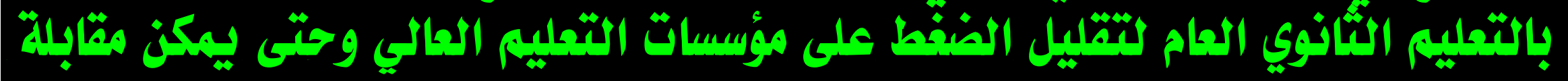

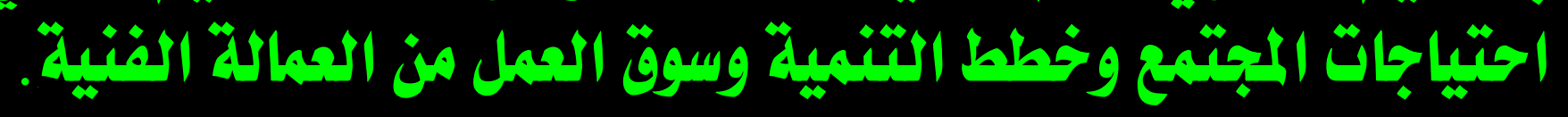

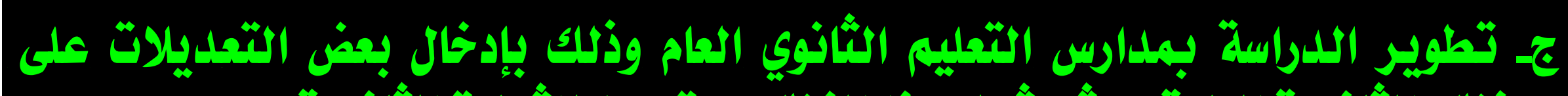

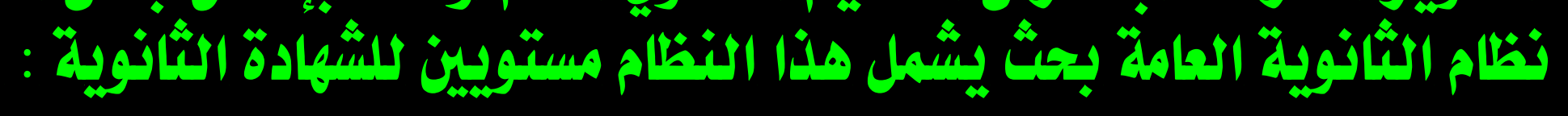

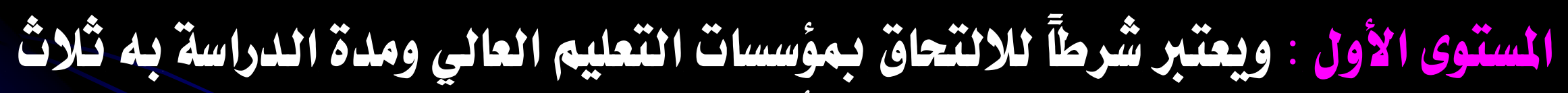

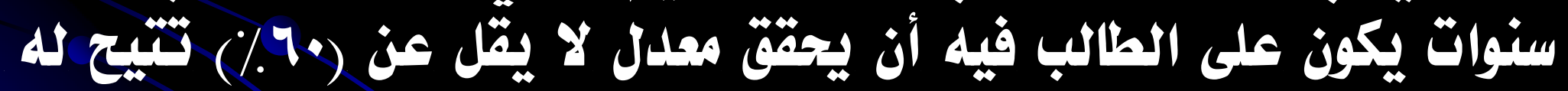

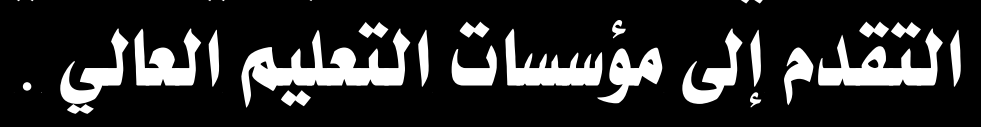

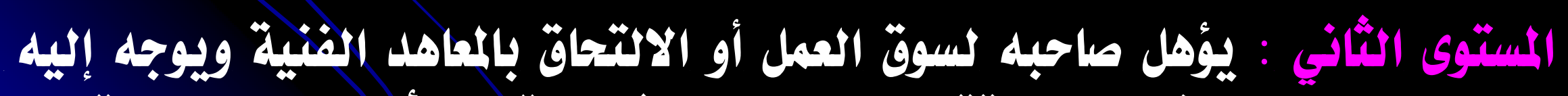

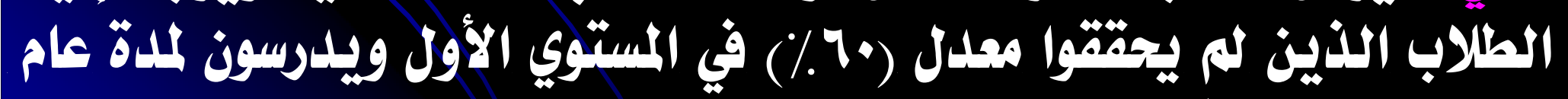

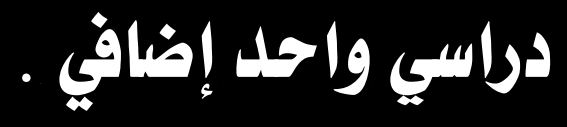

\begin{tabular}{|c|c|}
\hline 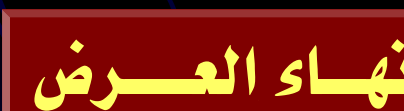 & $2 \sin$ \\
\hline
\end{tabular}




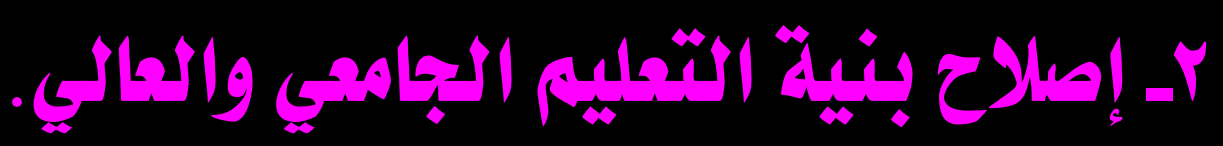

ويمكن أن يثم ذلك من خلال دراسة هياكل التمليم العالي واختيار ما يناسب

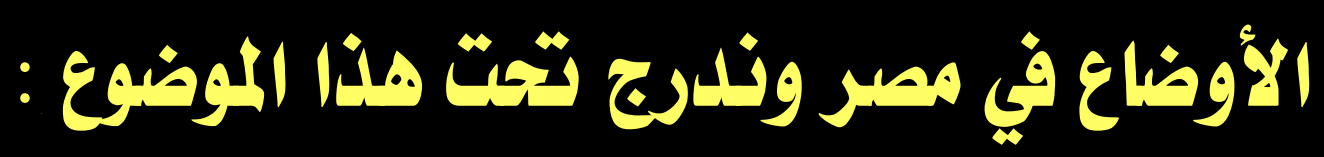

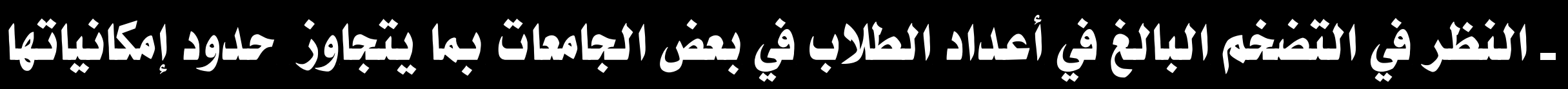

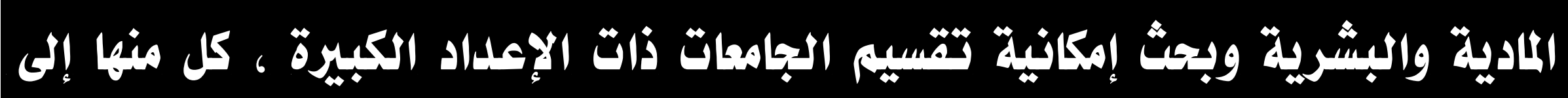

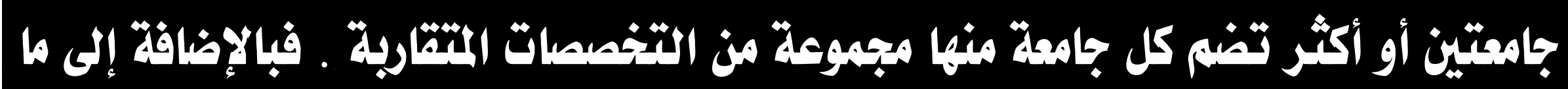

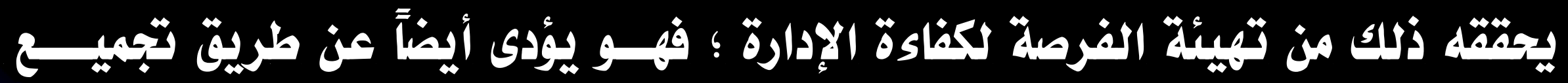

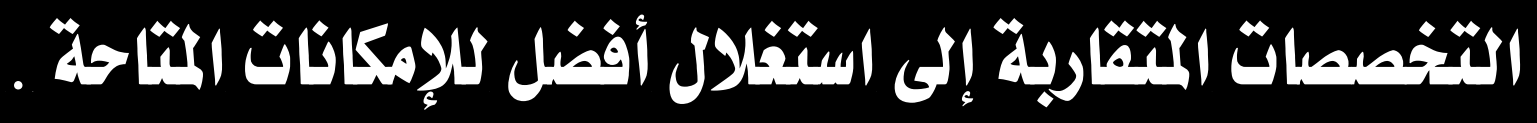


- النظر في أوضاع الماهد العليا والكليات التى تثبع وذارة التقليم العالي وملى إمكانية

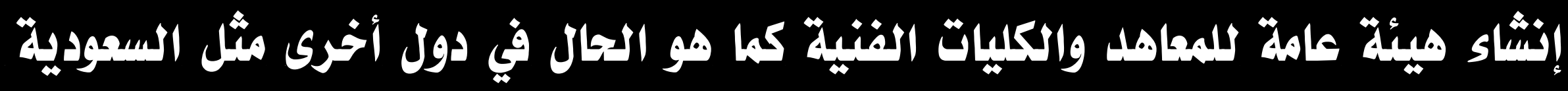
والكميت والأردن وانجلترا وفرنسا.

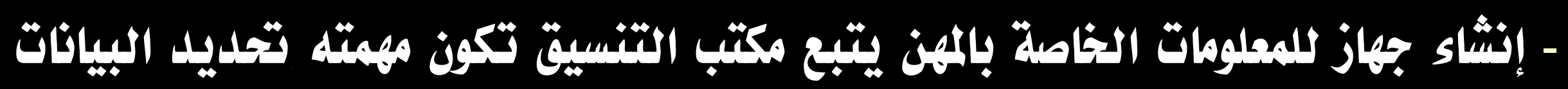

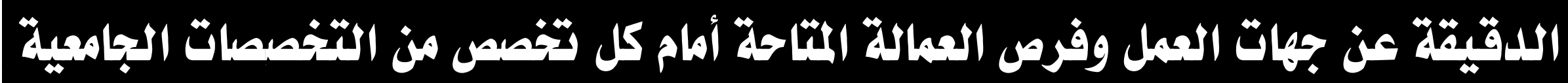

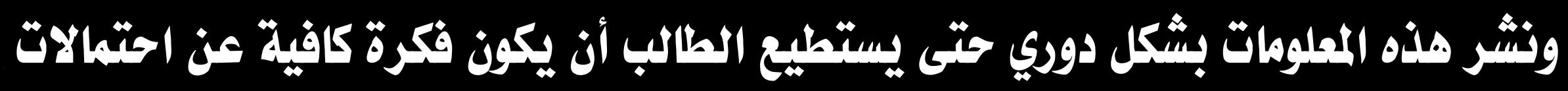

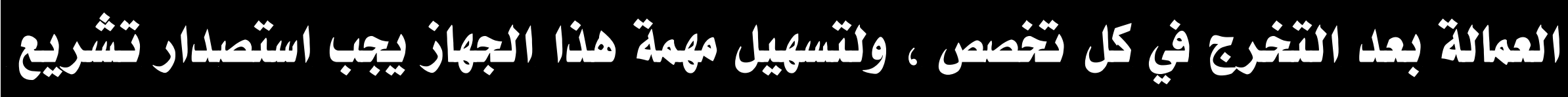
يلزم جهات العمل المغتلفة بتزويله بكل البيانات الغاصة بحاجاتها من العمالة. 


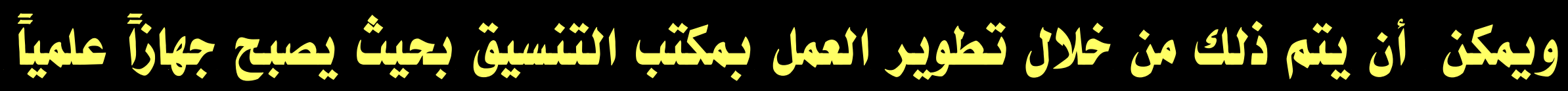

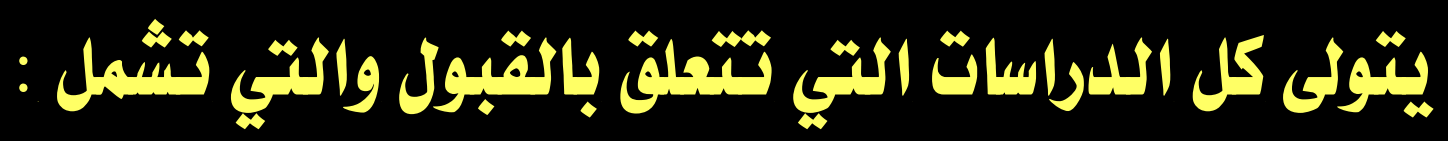

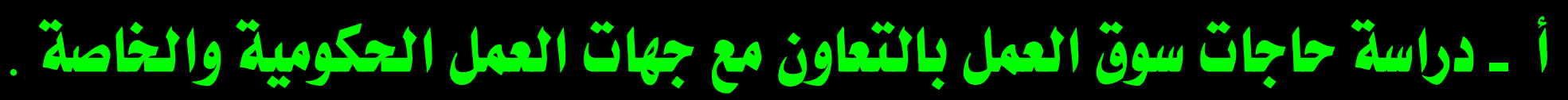

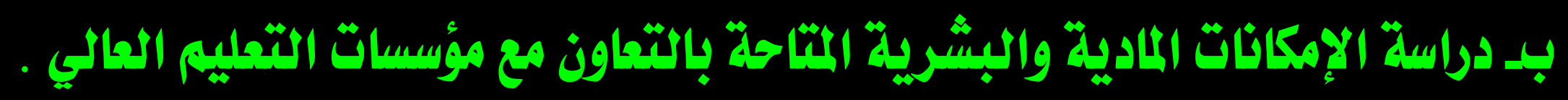

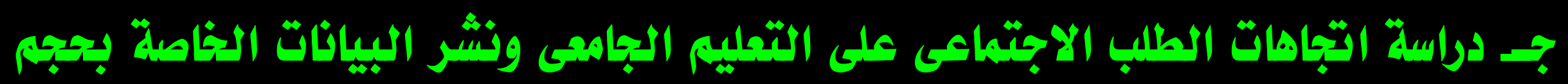

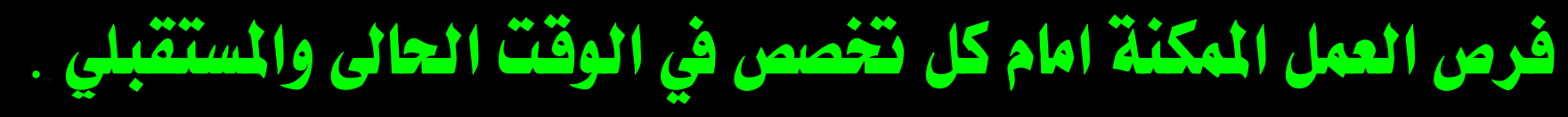

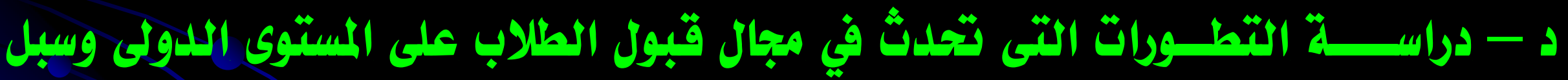
| الاسثثارة منها. 
في ضوى النتائه التى أسفرت عنها هذه الدراسة يقتزج فريق البمث أن يتم

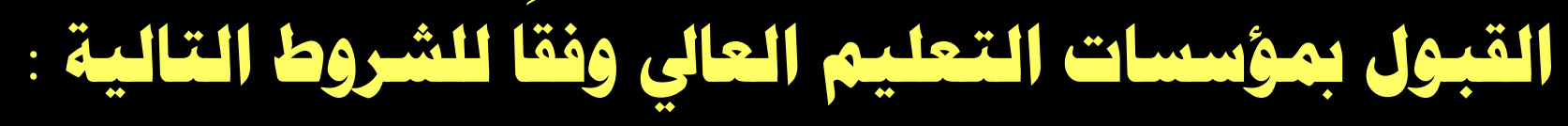

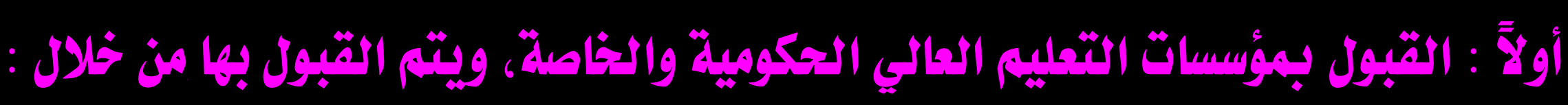

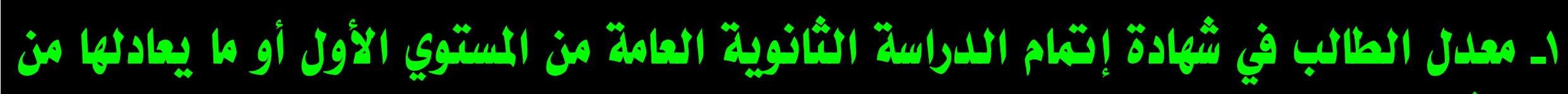

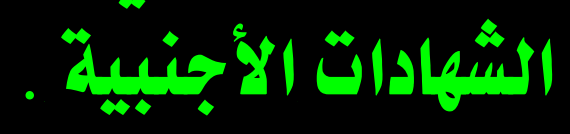

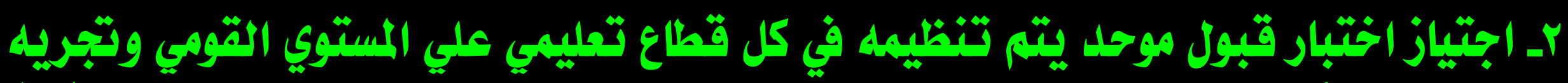

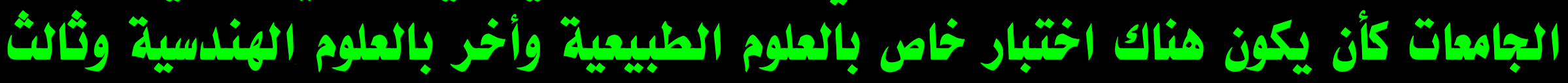

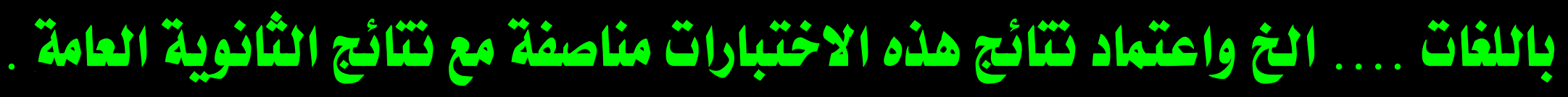

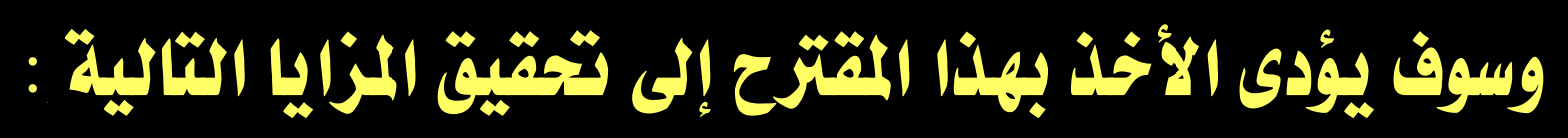

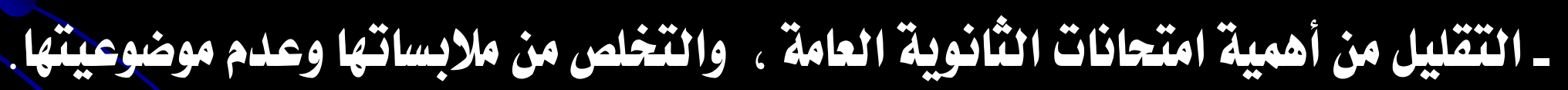

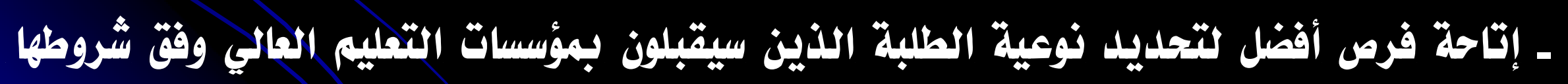

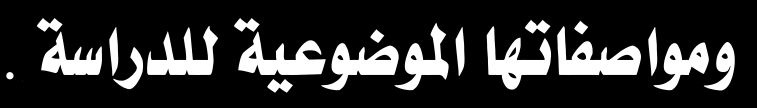

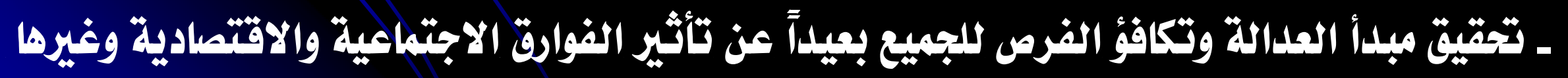
إنهـاء العــرض

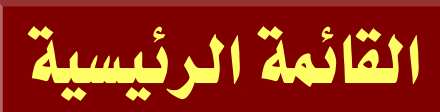

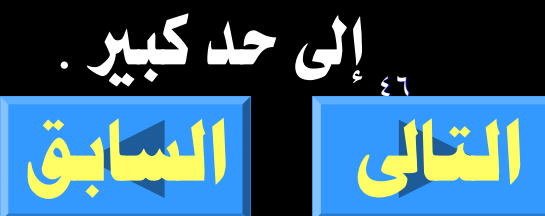


ـ القضاء أو التخفيف من ثاهرة الدروس الخصوصية الآخذة في الأزدياد باعتبارها أهم مستلزمات

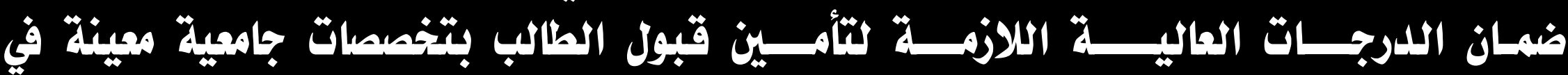

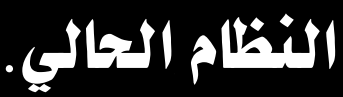

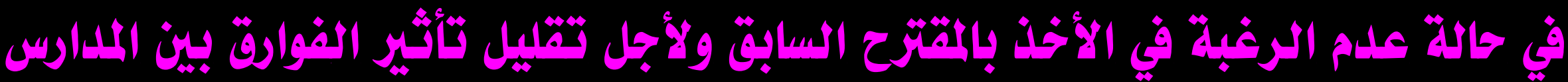

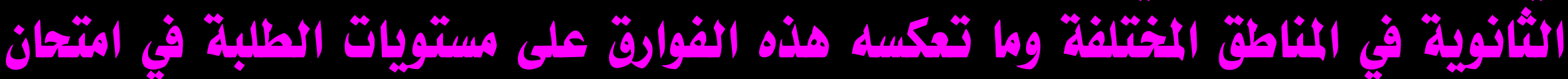

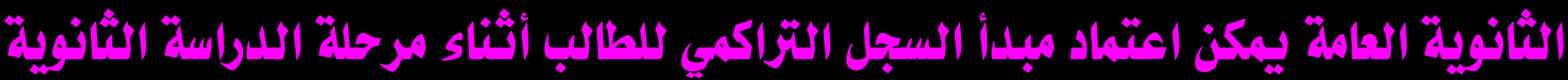

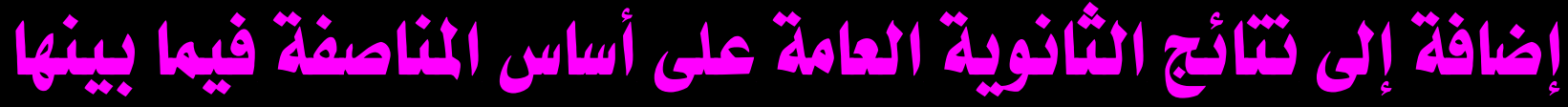

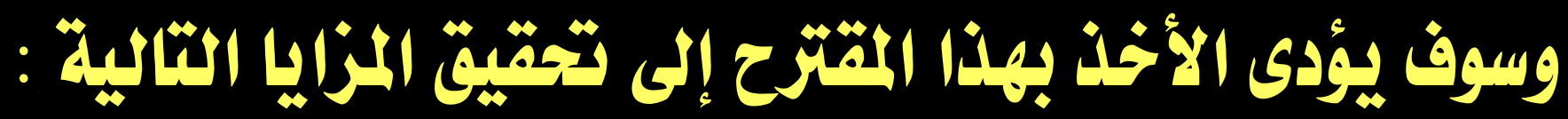

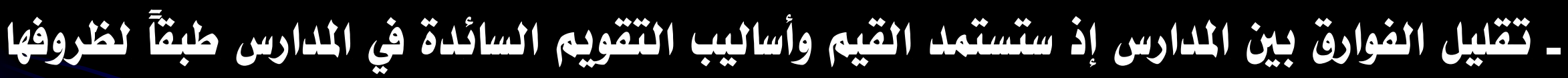

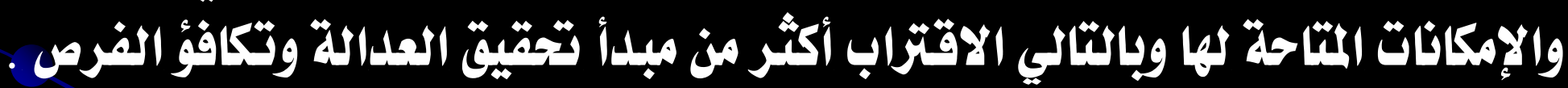

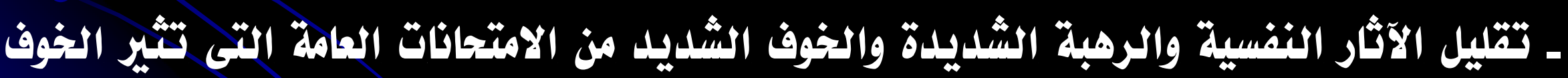

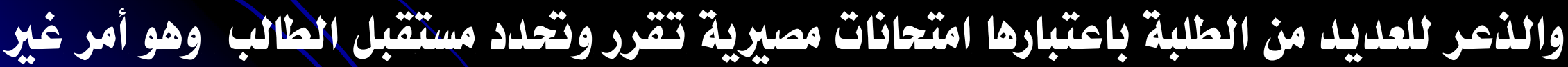
مرغوب فيه تربيوياً وتمليمياً. 
ـ الثضاء أو التخفيف من ثاهرة الدروب الخصوصية الآخذة في الازدياد باعثبارها أهم مسثرزات ضمان

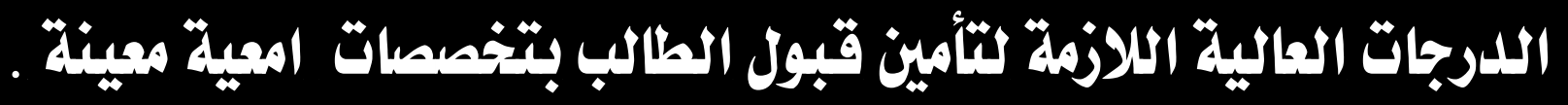

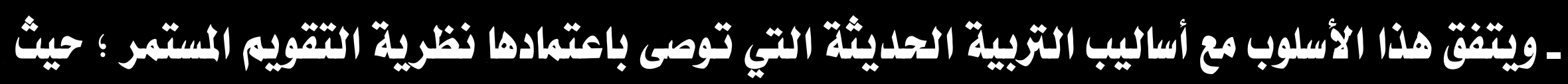

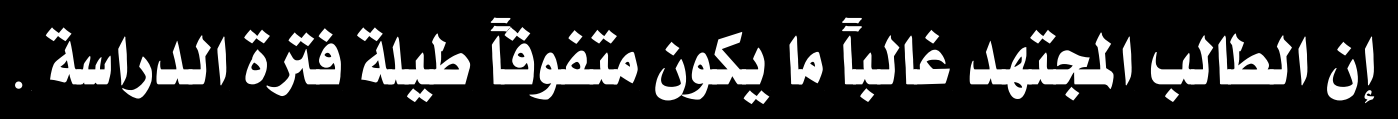

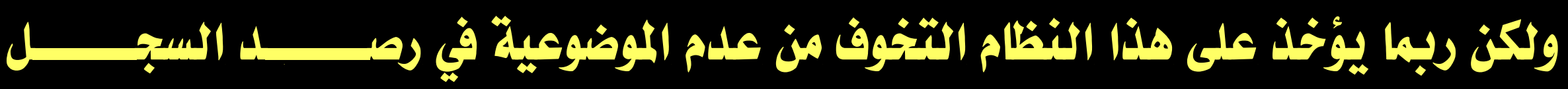
التراكمي بالطالوب

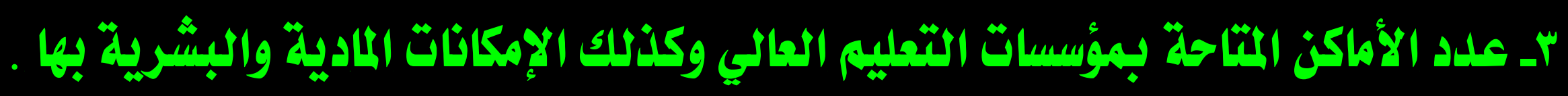

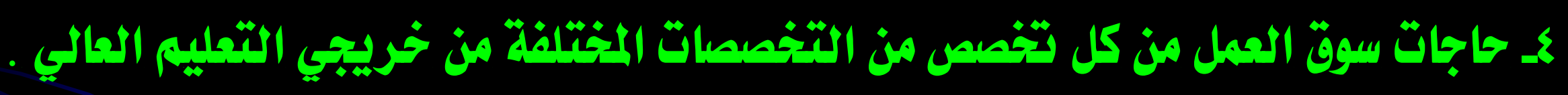

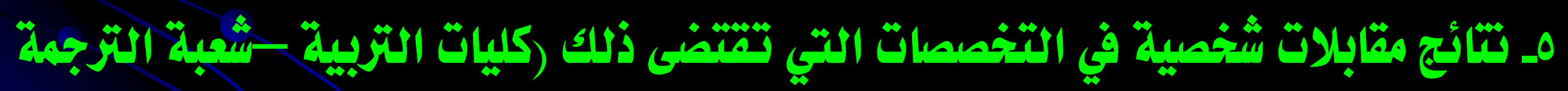

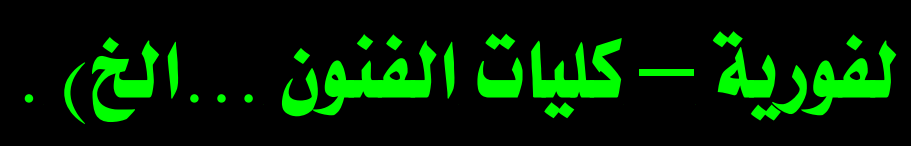




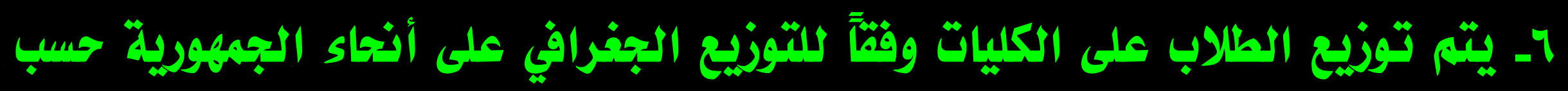

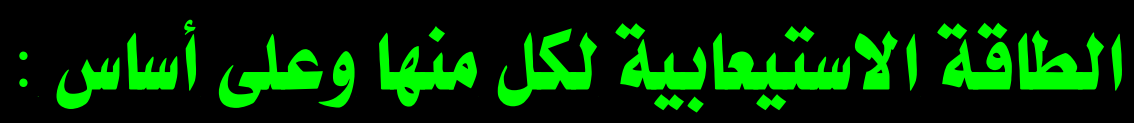

(مكان الحصول على الثانوية المامة - رغبة الطالب - الإجموع الكلى - تشيجة اختبار

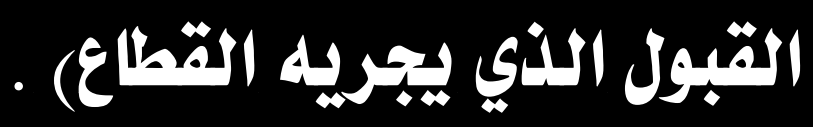

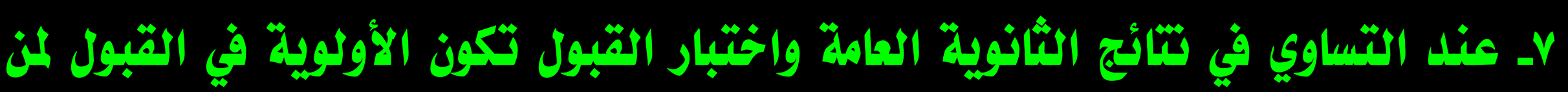
حصل على درجات أعلى في المواد المأهمالة.

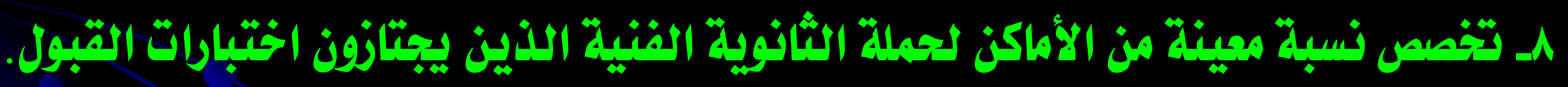

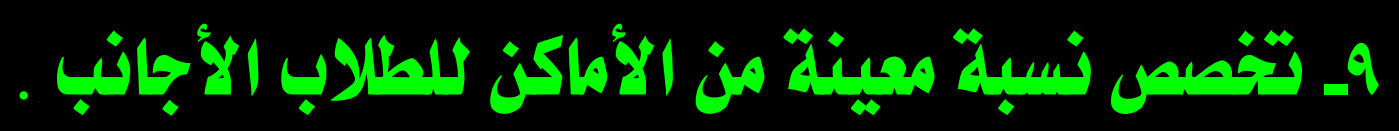




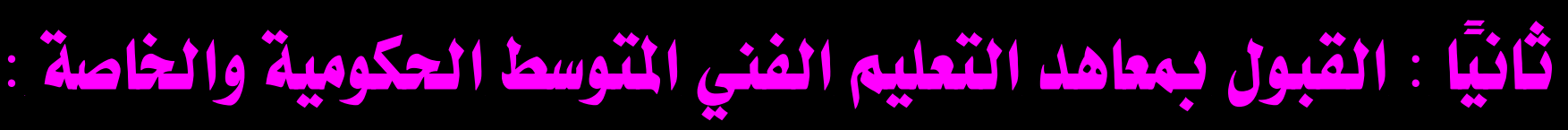

يكون القبول مفتوحاً لجميع الحاصلين على شهادة الثانوية العامة من الاستوي العادي

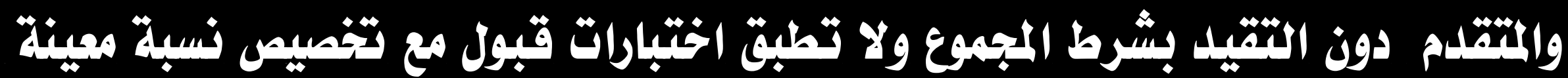

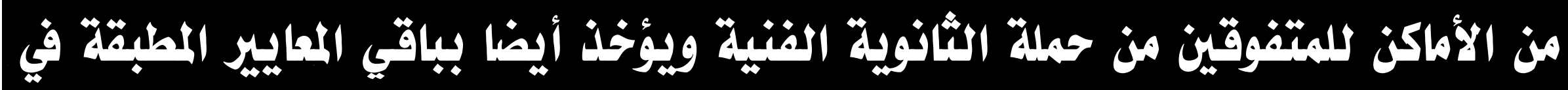
قبول الطالاب بالجامعات عدا الفترة الأخيرة. 


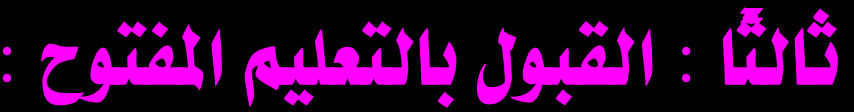

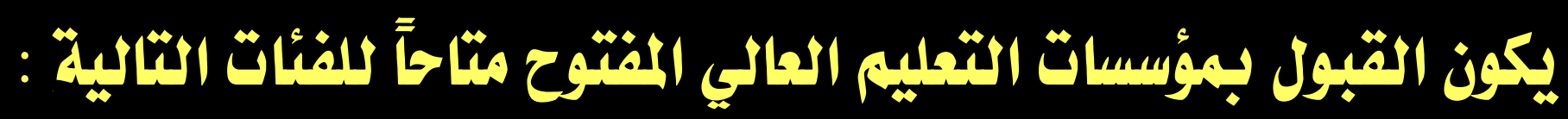

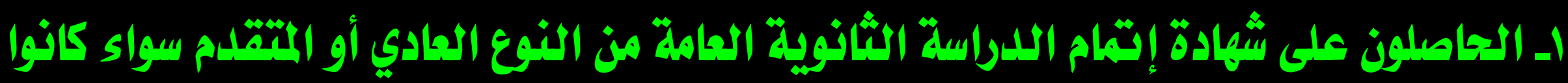

$$
\text { حليثي القخرج أو في سنوات سابثة . }
$$

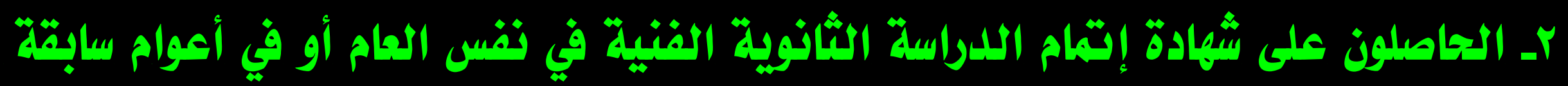
ويرغبون في مواصلة دراساتهى الجاميهية .

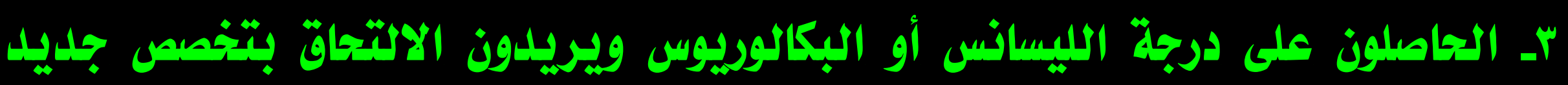
يتمشى مع رغباتهم وهيولهيم.

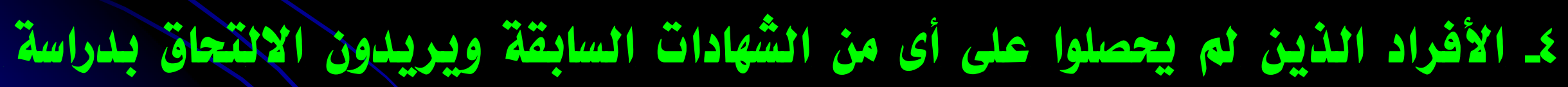

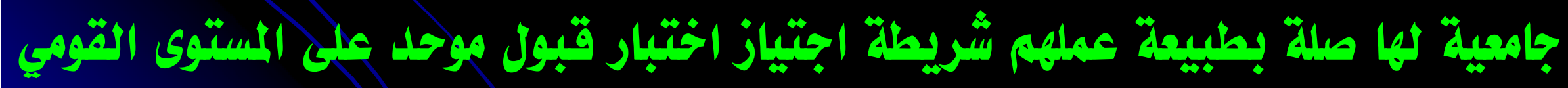

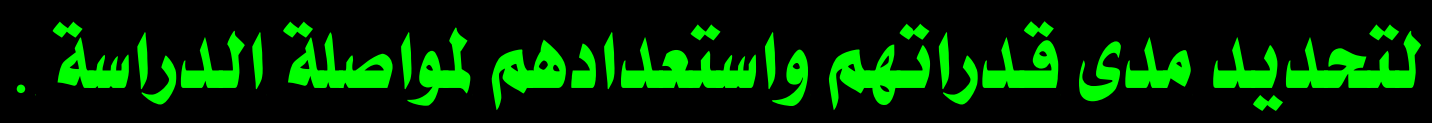




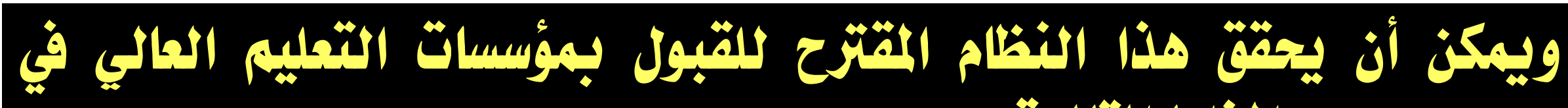

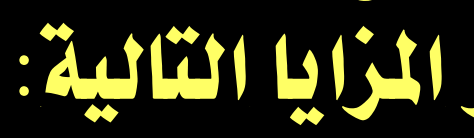

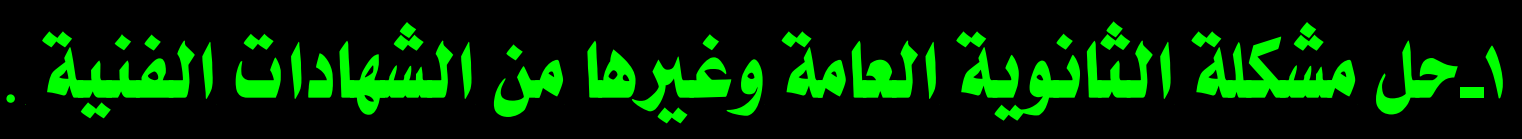

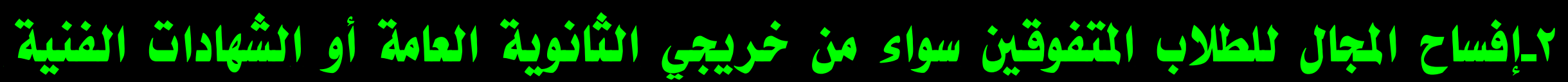

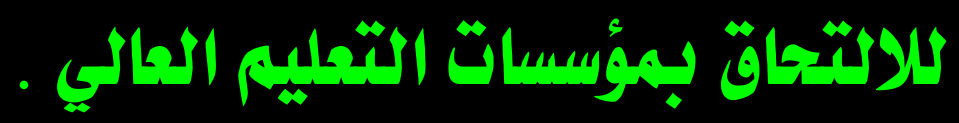

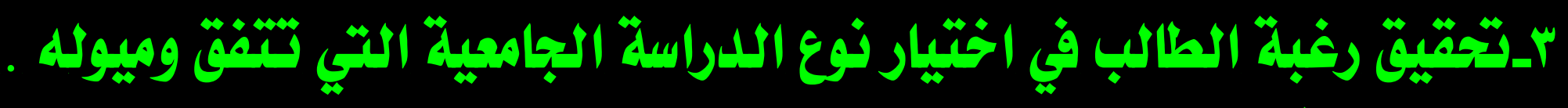

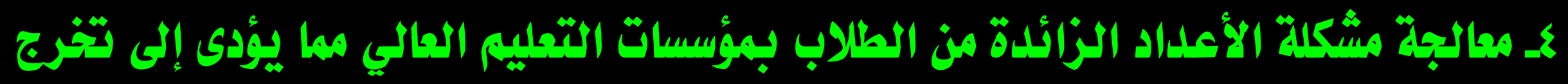

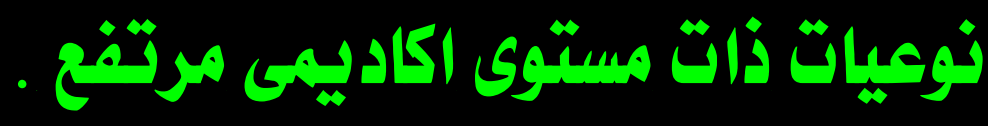

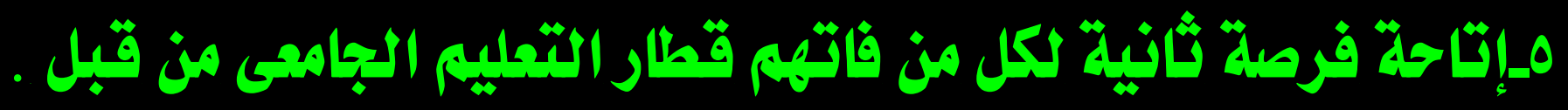

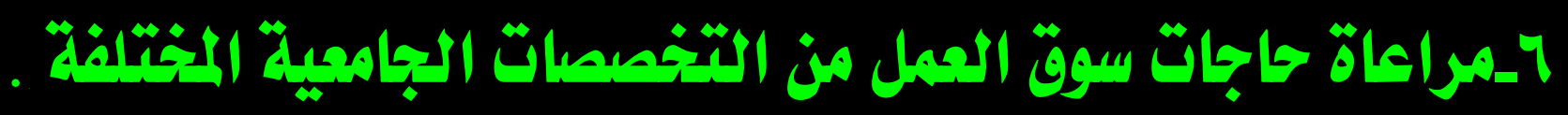

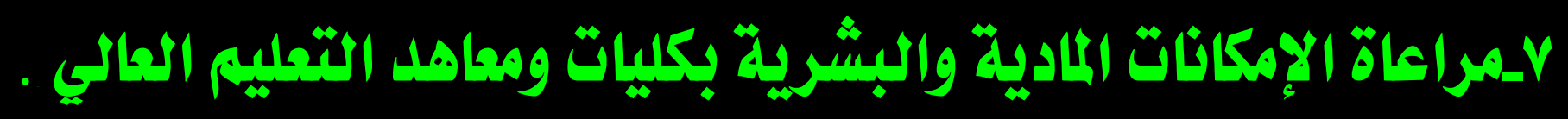

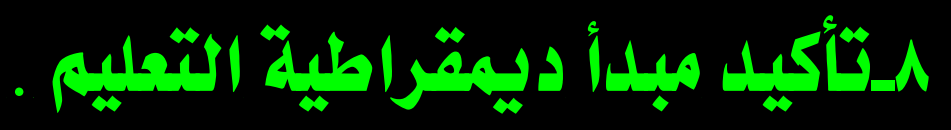

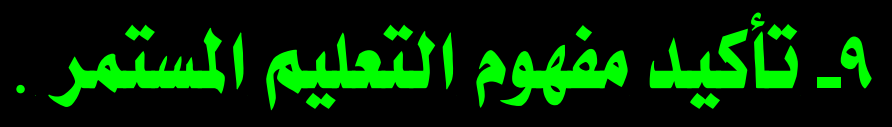

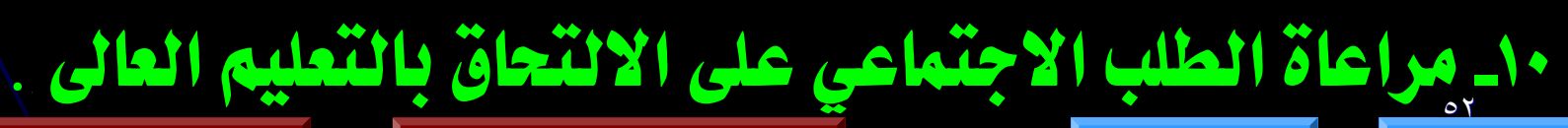

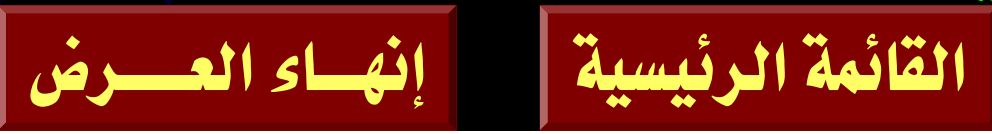


وقد يؤخذا علي هذا النيّام المقترح السابيات التالية :

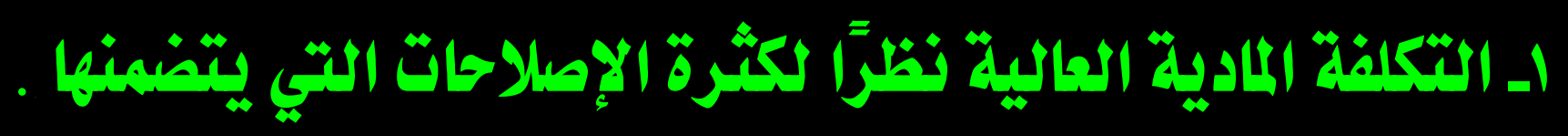

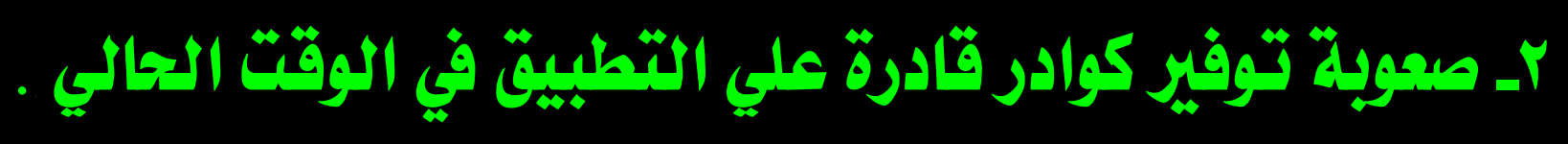

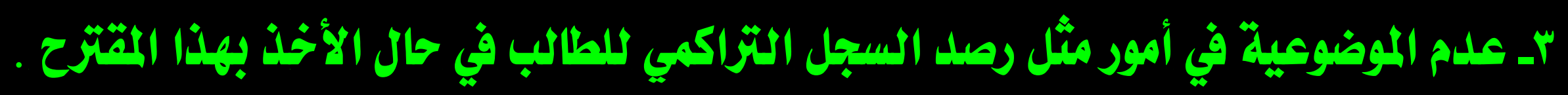

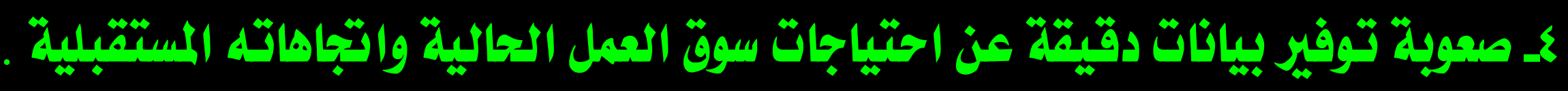

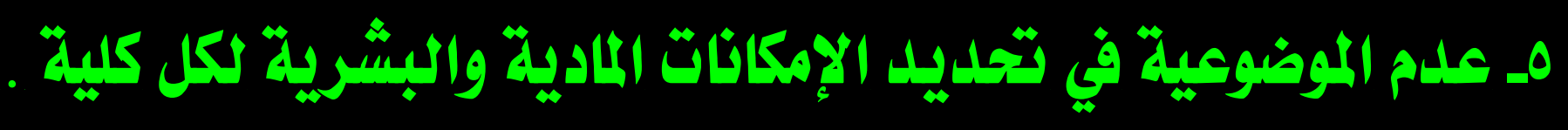




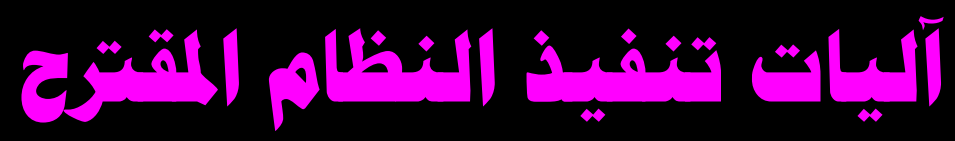

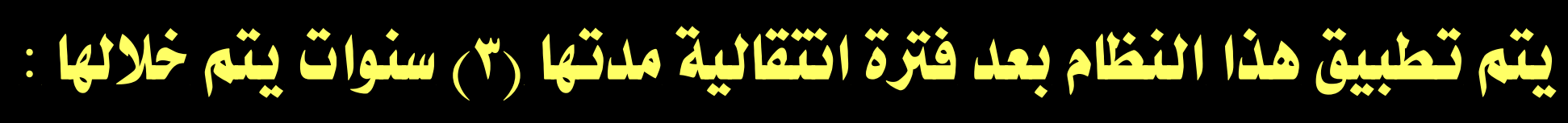

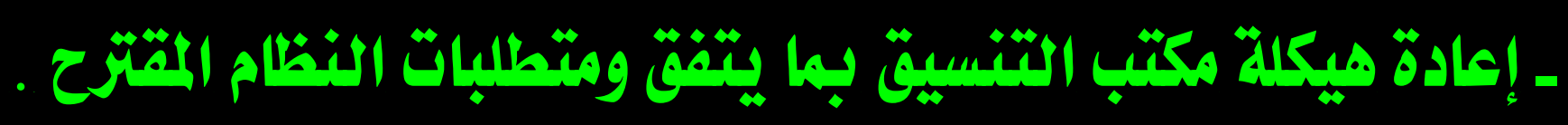

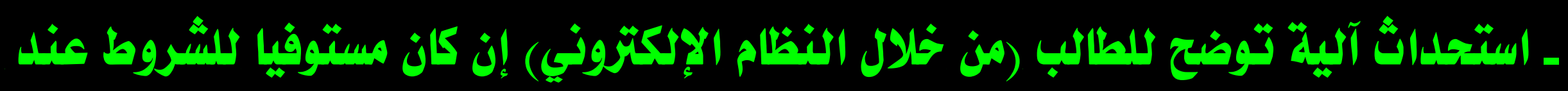

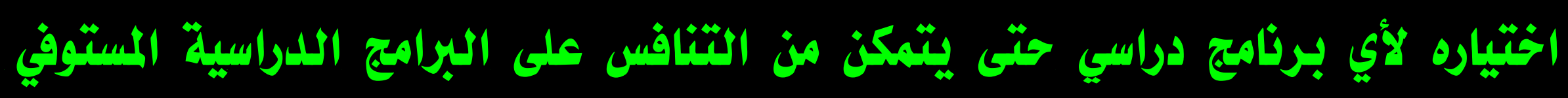
شُروطها.

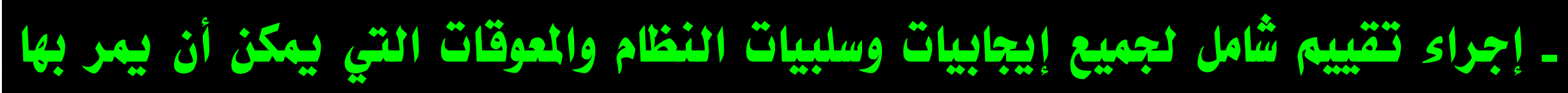

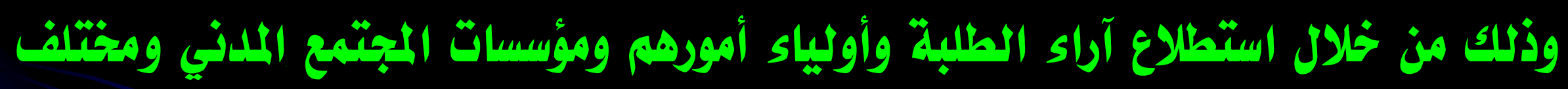

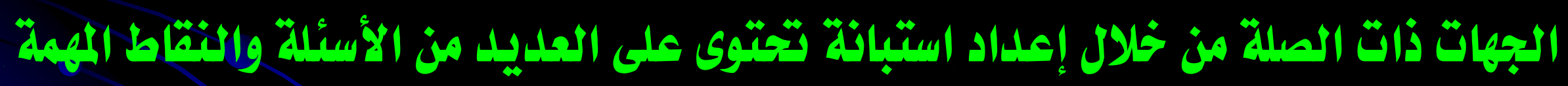

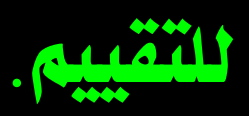

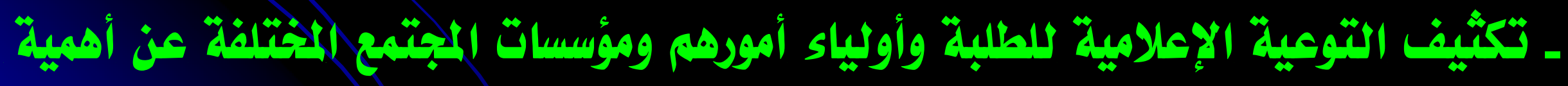

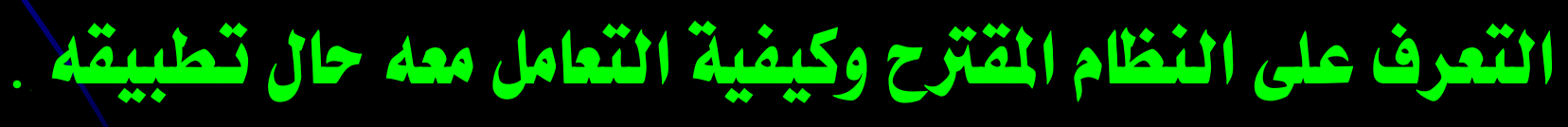

\begin{tabular}{|c|c|}
\hline مـرف & لئئمة \\
\hline
\end{tabular}




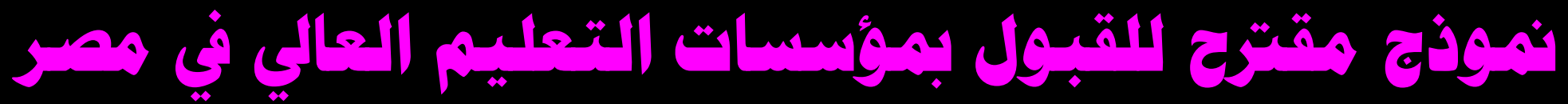

\section{مكتب يتولي الدراسات العلمية لكل ما يتعلق بسياسات القبول}

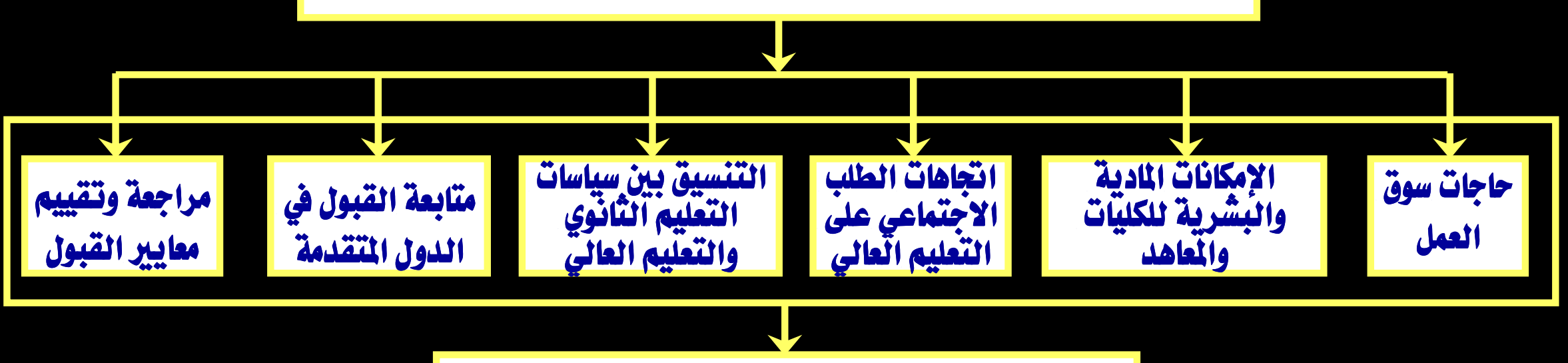

معايير القبول ببؤسسات التعليم العالي

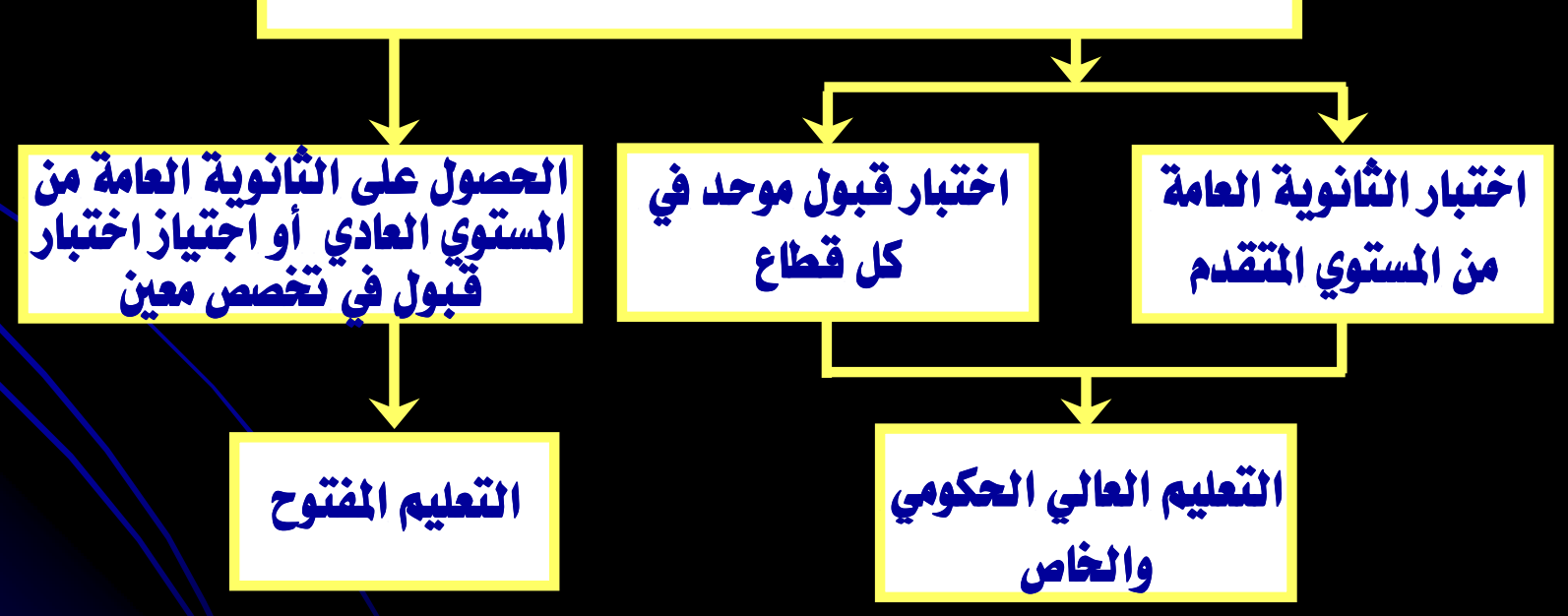

$$
\text { إذهــاء الهـــرض }
$$




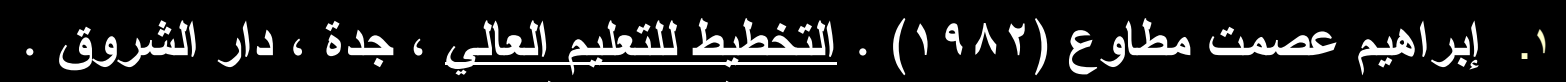

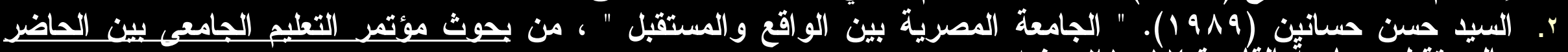

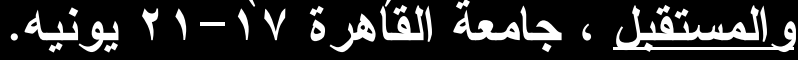

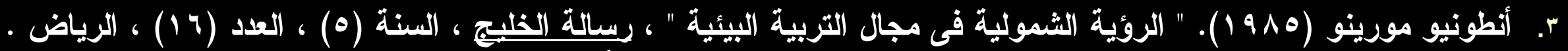

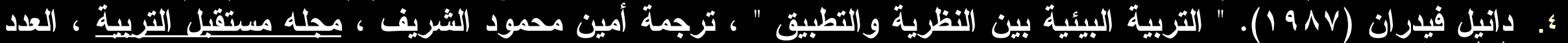

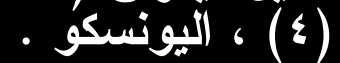

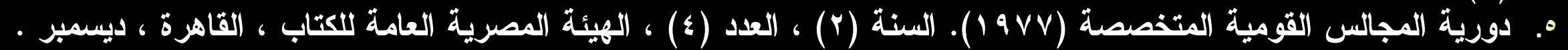

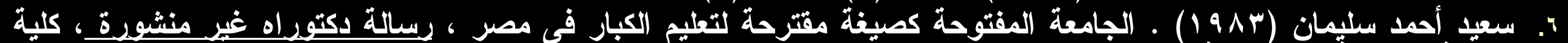
التربية ، جامعةً الإسكندرية .

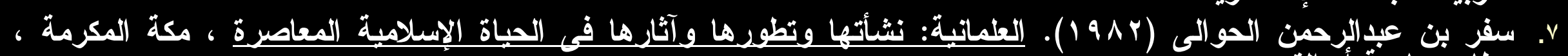

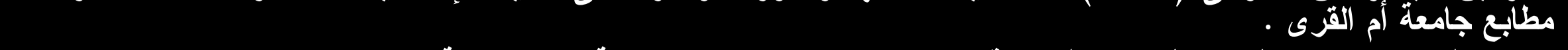

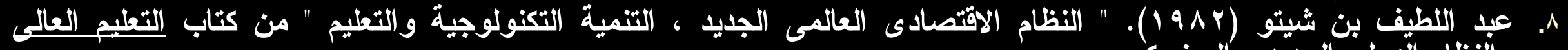

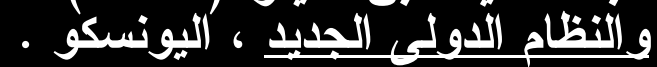

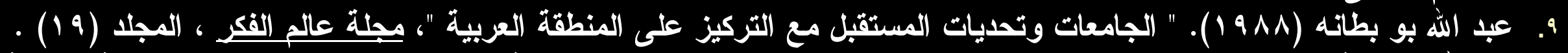

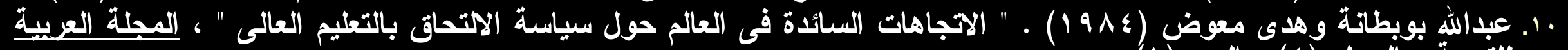

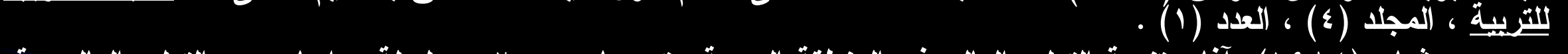

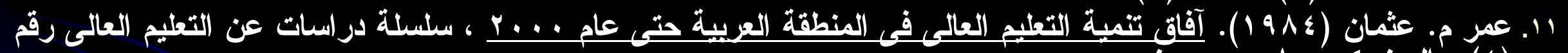

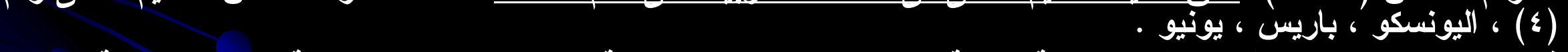

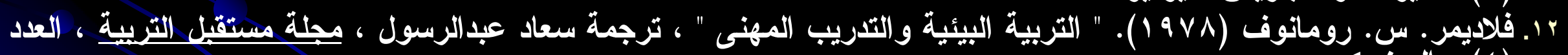

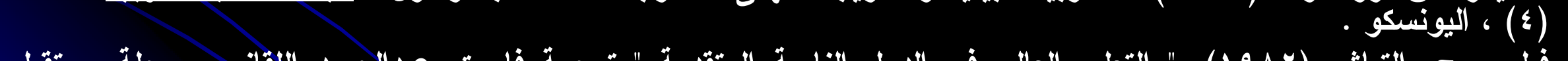

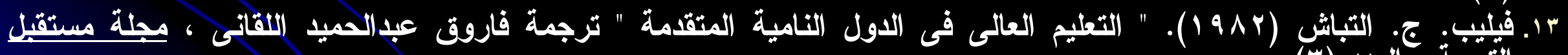

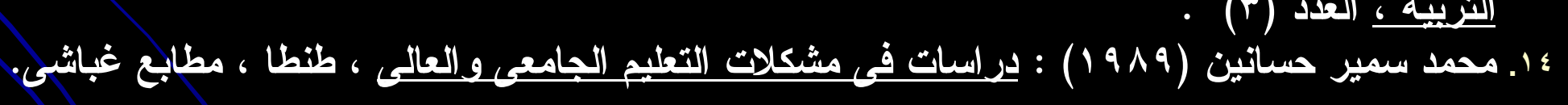




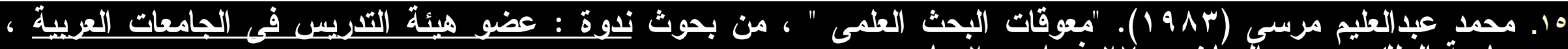

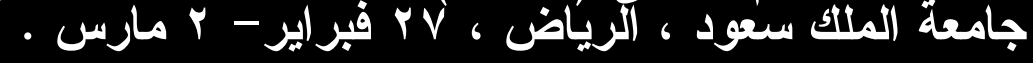

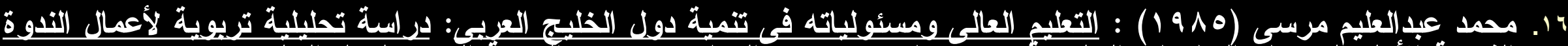

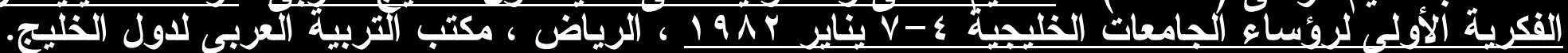

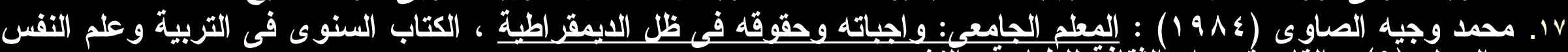

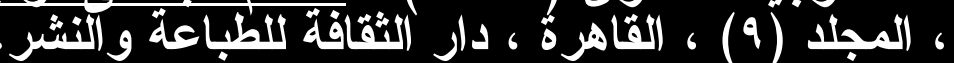

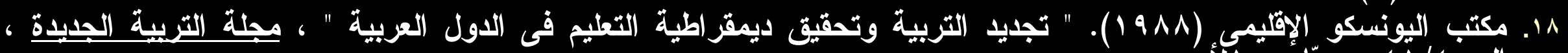

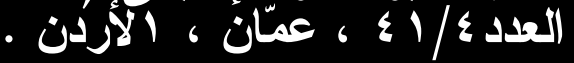

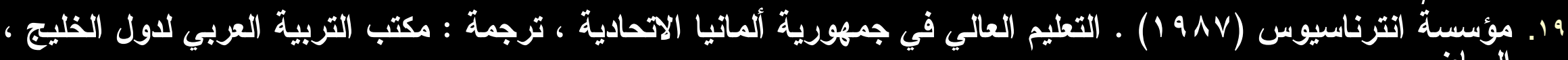

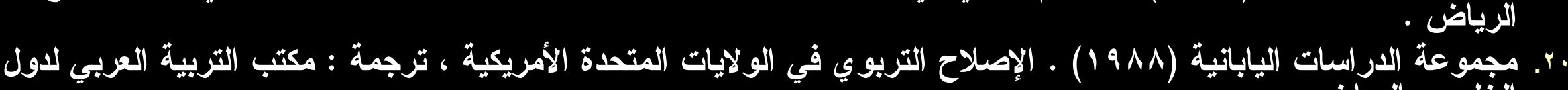

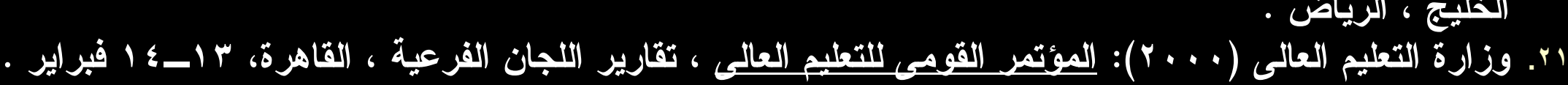

22. Ch. Oehler (1986): Aspects of Higher Education, Planning in Market Economy Systems, in Planning Higher Education, CEPES, Bucharest Unesco.

23. Donald S. Doucette (1982): Higher Education in The United States, CEPES, Bucharest, Unesco.

24. E. Eugene Oliver (1980): Establishing Admission Policy, in James Quann's: Admission, Academic Records and Registrar Services, San Francisco, Jossey-Bass Publishers.

25. Ingo Richter (1988): "Selection and Reform in Higher Education in Western Europe", Comparative Education, Vol .(24), No.(1).

26. James, Q. et al (1980): Admission, Academic Records and Registrar Services, San Francisco, Jossey-Bass Publishers

27. Krestin Elisson (1980): Problems in The Relationship Between Education and Employment in Sweden, Division of Educational Policy and Planning, Paris, Unesco.

28. Unesco (1982): World Guide to Higher Education, Paris, Unesco.

29. W. Vollman edition (1985): Higher Education in The Ukranan SSR, CEPES, Bucharest, Unesco.

30. Wood Michael (1987): Early and Concurrent Colleges Admission Practices in The State of Michigan, Ph. D. Dissertation, University Microfilms International, Michigan, Ann Arbor,.

31. I.A.U (1980): Seventeenth General Conference, Manila 25-30 August, , Summary Report .

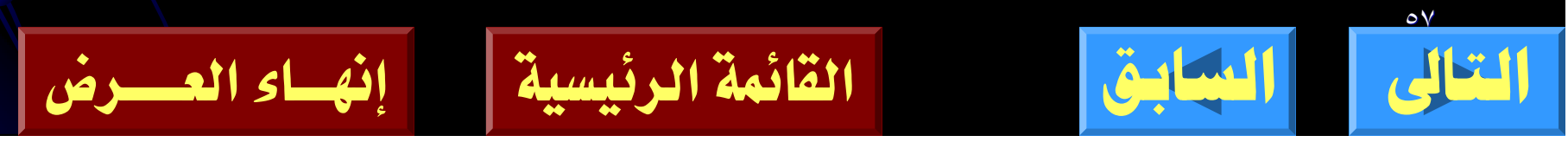

